


CHARLES PERRAULT 



\section{CHARLES PERRAULT Memoirs of My Life}

Edited and translated by Jeanne Morgan Zarucchi

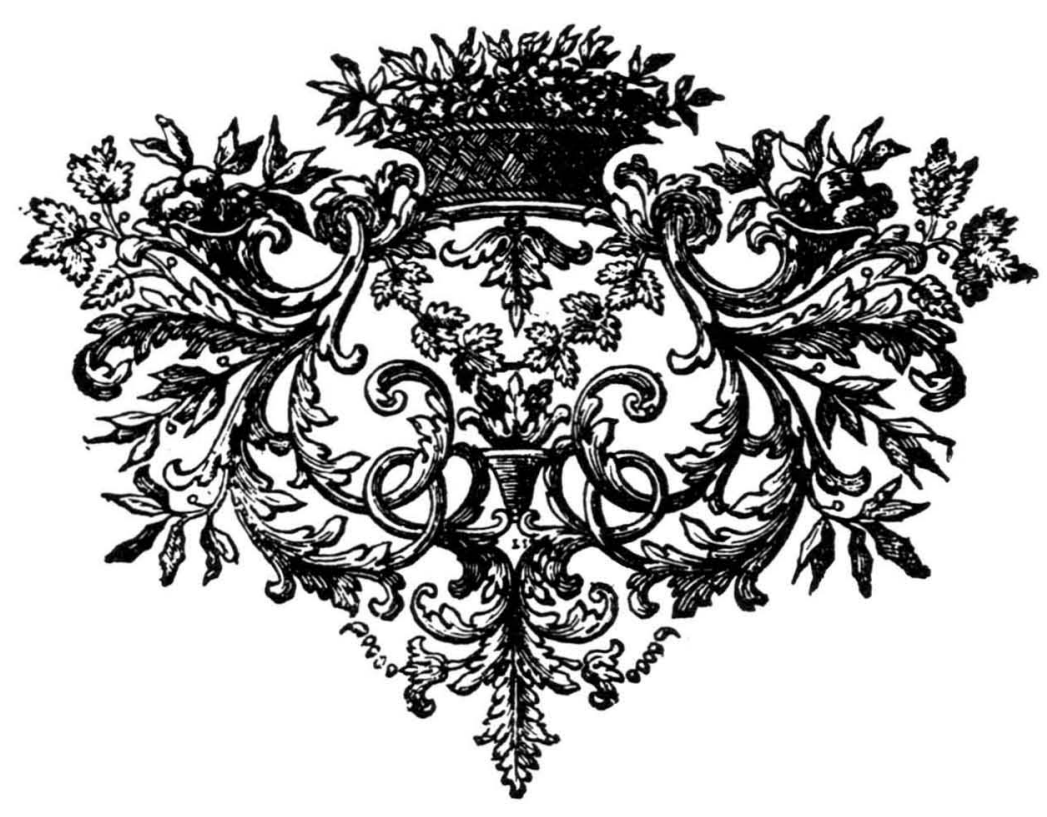

University of Missouri Press

Columbia, 1989 


\section{Copyright (C) 1989 by}

The Curators of the University of Missouri University of Missouri Press, Columbia, Missouri 652II

Printed and bound in the United States of America All rights reserved

\section{Library of Congress Cataloging-in-Publication Data}

Perrault, Charles, I628-1703.

Charles Perrault : memoirs of my life / edited and translated by Jeanne Morgan Zarucchi.

$$
\text { p. cm. }
$$

Bibliography: $\mathrm{p}$.

Includes index.

ISBN o-8262-0667-o (alk. paper)

I. Perrault, Charles, 1628-1703-Biography. 2. Authors, French-17th century-Biography. I. Zarucchi, Jeanne Morgan.

II. Title.

PQ1877.A8I5 1989

$84 \mathrm{I}^{\prime} \cdot 4$-dcI9

[B]

88-39865

CIP

$\infty^{T M}$ This paper meets the minimum requirements of the American National Standard for Permanence of Paper for Printed Library Materials, Z39.48, 1984 . 


\section{ACKNOWLEDGMENTS}

Research for the preparation of this volume was generously supported by grants from the University of Missouri-St. Louis Weldon Spring Humanities Seminar and Summer Research Fellowship funds. The author wishes to thank the Bibliothèque Nationale (Paris), the Metropolitan Museum of Art (New York), and the Library of Congress (Washington, D.C.) for permission to reproduce illustrations from their collections. Sincerest appreciation is also expressed for the cooperation and invaluable assistance provided by the staffs of the Bibliothèque Nationale and Archives Nationales in Paris, the Center for International Studies and the Office of Research Administration of the University of Missouri-St. Louis, Professor Louis van Delft of the University of Paris, Professor Martha Houle of the College of William and Mary, and my husband, James L. Zarucchi.

J. M. Z.

St. Louis, Missouri

January 1989 



\section{CONTENTS}

Acknowledgments, v

Introduction, I

A Note on the Text, 26

Part I. The Early Years, 29

Part 2. Colbert and the Academies, 4I

Part 3. The Louvre, 54

Part 4. Art, Patronage, and Power, 83

Part 5. Public Service, Private Struggle, IO2

Appendixes

A. "Letter to Mademoiselle," II6

B. "Speech of Thanks to the Gentlemen of the Academy," II7

C. Preface to the Tales in Verse, $\mathrm{I} 2 \mathrm{O}$

D. "Some Superstitions and Popular Errors," "Paradox," I24

E. Funeral Eulogy of Charles Perrault, 126

Chronology of Life and Principal Works, I29

Selected Bibliography, I32

Index, I35 
He placed his whole family in comfort. He purchased newly created posts for his father and for his brothers; and in so doing he established them all, and paid court perfectly at the same time.

-Conclusion of Little Thumbkin 


\section{INTRODUCTION}

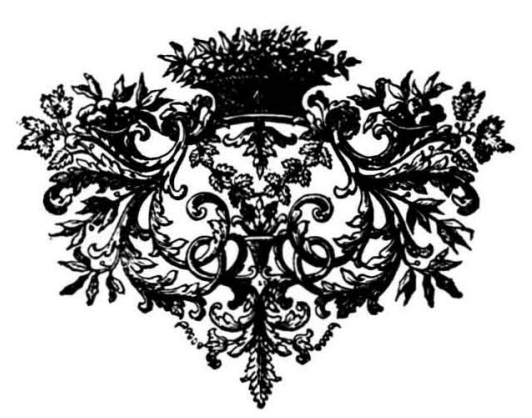

On I6 March I660, a man who was ultimately to become the most powerful administrator in the reign of Louis XIV wrote a letter to his employer and patron, the King's Prime Minister. This letter did not deal exclusively with finances or matters of state, as might have been expected in an exchange between men of such stature as Jean-Baptiste Colbert and Cardinal Mazarin. Instead, it included the following passage: "Since Your Eminence has been pleased by the ode which I sent, and desires to know the name of its author, it is Perrault, a lawyer in Parliament, who has a certain genius and writes very good verse."I

In this way, in a letter between two statesmen expressing admiration for a poem, began the career of a man who would exemplify the interrelation of politics and art in France in the latter half of the seventeenth century. Charles Perrault was a dynamic figure who played a dual role, as an administrator of the King's buildings charged with promoting the physical manifestation of the monarch's glory, and as an artist in his own right, a prolific author whose mottos and devices adorned monuments and medals, and whose poetry won acclaim before the French Academy.

It is Perrault's writings that have achieved the greatest fame over time, and one work in particular is renowned and beloved throughout Western culture, although paradoxically, its author remains virtually unrecognized. If one were to ask an English speaker to identify the source of "Little Red Riding Hood," "Cinderella," and "Sleeping Beauty," the most likely answer would be "Grimm's Fairy Tales," or even just "tradition." The famous Brothers Grimm, however, were merely the collectors of numerous versions of tales that had first been printed over one hundred years before, in I697. The original versions of these stories were written by Charles Perrault.

It is also not commonly understood that in their own day, the fairy tales were simply part of a body of writings of a respected Academician, who sought in his work to forge an identity separate from his political role. Even for Perrault the writer, however, patronage and inspiration were inseparable. Throughout the course of a

I. Lettres, instructions et mémoires, ed. Clément (Paris: Imprimerie Impériale, I86I), I:440. 


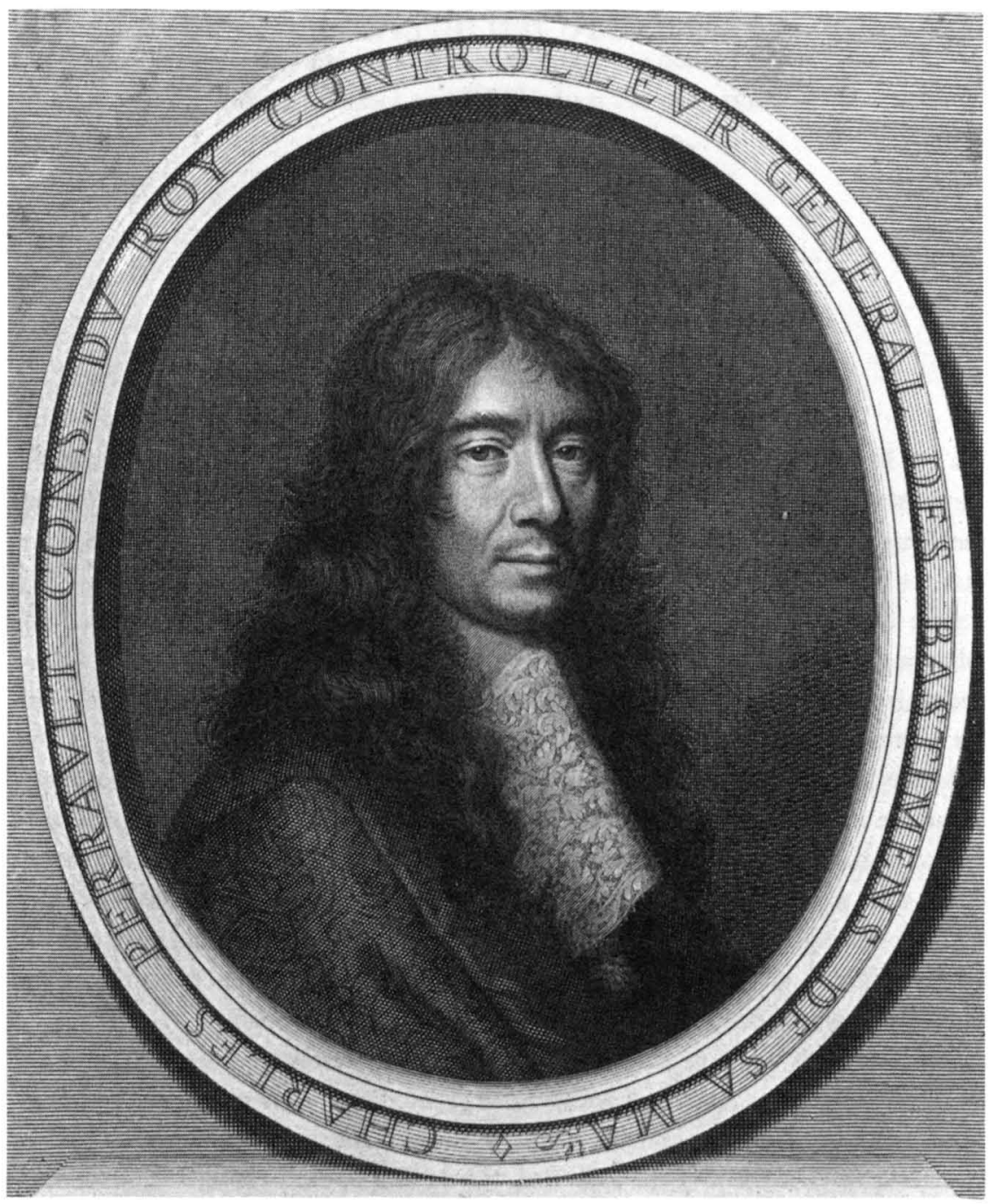

Charles Perrault. Engraving by Baudet, after painting by Le Brun, I665. Courtesy Bibliothèque Nationale.

career spanning five decades, Perrault's creative activity would be informed by his awareness that the written word carries political weight.

Patronage was of course a fact of artistic life in the seventeenth century. Writers, painters, sculptors, and musicians commonly attached themselves to the retinue of a noble benefactor for reasons of both economic survival and prestige. In turn, the content of artistic works was undeniably influenced. Eulogies, homages, and idealized portraits proliferated, and circumstantial poetry was perhaps lamented as a necessary hypocrisy by its authors, but was in public widely admired. 
The relation between art and politics, however, transcended the simple practicality of sponsorship. When Cardinal Richelieu founded the French Academy in I635, he envisioned a body of men esteemed in letters and theology, who would direct their energies toward the service of the monarch, then Louis XIII. The Academy's official charge, to produce a dictionary of the French language, represented a move toward the codification of thought and the imposition of structure upon creative expression, at the same time that Richelieu was accomplishing a centralization of political power.

When Cardinal Mazarin died in I66I, the young Louis XIV began a personal rule, unassisted by a prime minister, and handpicked the men who were to carry out his will. Within a year, he had dismissed Nicolas Fouquet, Mazarin's choice as Superintendent of Finance, whose personal wealth and influence were a threat to the King despite Fouquet's administrative competence and admired generosity toward the arts. Fouquet was replaced by one of his own subordinates who had helped to engineer revelations of Fouquet's misappropriation of funds and bring about his disgrace: JeanBaptiste Colbert.

Colbert was to achieve a subjugation of art to the will and pleasure of the monarch that would reach unprecedented heights and was to provide the impetus for Perrault's unique career. Among Colbert's responsibilities was the superintendence of buildings constructed by and for the King, and the enormous amount of construction that took place during the early years of Louis XIV's personal reign reflected the King's and Colbert's belief that the appearance of majesty is a guarantor of power. It was essential that the historical palace of the French kings surpass that of any other rival monarch, and therefore the Louvre was enlarged and given a more imposing façade, in addition to work upon the secondary palaces of the Tuileries and Saint-Germain; the ousted minister Fouquet's château at Vaux-le-Vicomte was more lavish than any of the King's own residences, and therefore Versailles was rebuilt and embellished with virtually no expense spared. Less than ten years after the end of the Fronde, a revolt during which Louis XIV as a child had suffered humiliation at the hands of his own nobles, these manifestations of power conveyed an unmistakable message to the King's subjects.

With ingenious understanding not only of the King's need to assert an aura of majesty, but also of what in modern terms could only be called the art of public relations, Colbert further determined to establish a second, so-called Little Academy, the primary role of which would be to invent mottos for inscription upon these same buildings and monuments. Eloquent words were not only a means of embellishment, but also a kind of spiritual complement to the visual grandeur of an imposing structure.

When the Little Academy was founded by Colbert in I663, less than a year before he became Superintendent General of Buildings, it was also directed to embark upon what was to become an idealized history of the King's life in commemorative medals, which could be offered as gratifications to foreign visitors and even used in lieu of 
payment for services rendered. This project, which would come to be known as the "Metallic History of the King," deified his image and praised each minor military victory as the achievement of an Augustus. The degree to which the Little Academy succeeded in identifying commemorative medals with the larger-than-life persona of the King is perhaps best exemplified by the fact that in 1716, a year after the King's death, the production of medals ceased, and the Academy's title was changed from "Inscriptions and Medals" to "Inscriptions and Belles Lettres."

Colbert's involvement in an Academy of "eloquence" may appear to be contradictory to his more celebrated role as an administrator of finance and commerce. In the seventeenth-century view, however, there was no such abrupt separation between what might be considered artistic and bureaucratic domains. The official title he received on I January I664 was that of Superintendent-Director General of Buildings, Arts, Tapestries, and Manufactories of France; yet despite the seeming contrasts, each one of these areas represented an aspect of the monarch's glorification. In buildings, tapestries, and manufactories, which in preindustrialized France meant the workshops that produced fabrics and furnishings, the King's physical comforts were accommodated in such a way as to inspire aristocratic envy and public awe; the role of the arts was simply to determine the subject matter and form. Even the word art in seventeenth-century French meant not only the familiar abstract concept associated with creative activity, but also the technique or skill by which something is accomplished.

Colbert's vision of an Academy was also not restricted to that of an assemblage of men of letters. In 1666, he established the Academy of Sciences, and, as in the case of literature, scientific accomplishment was valued less for its intrinsic worth than for its expediency in Colbert's global aim of promoting the King's public image. Its mission was less direct than that of the Little Academy, but the inventions and accomplishments of its members would nevertheless serve to inspire awe of the monarch in whose service they labored. Other academies were soon founded or expanded, including the Academy of Architecture in I67I and the Academy of Music in I672. These academies were useful for international propaganda as well; the Royal Academy of Painting and Sculpture, previously established by Mazarin in 1648, opened a subsidiary school in Rome in 1666 , ostensibly for the purpose of giving French students an opportunity to study the masterworks of Italian art, but also to establish a French artistic presence in Rome as a subtle challenge to the Italians' prestige.

The involvement of Charles Perrault in Colbert's grand scheme was in part a measure of Perrault's talent, and in part a result of advantageous connections. Perrault's older brother had risen through the ranks with Colbert, as junior finance clerks in the service of various officials, and had purchased a position as Receiver General of Finances, essentially a tax collector, for the city of Paris. Such positions were highly coveted for their immense potential for graft, but Pierre Perrault was 


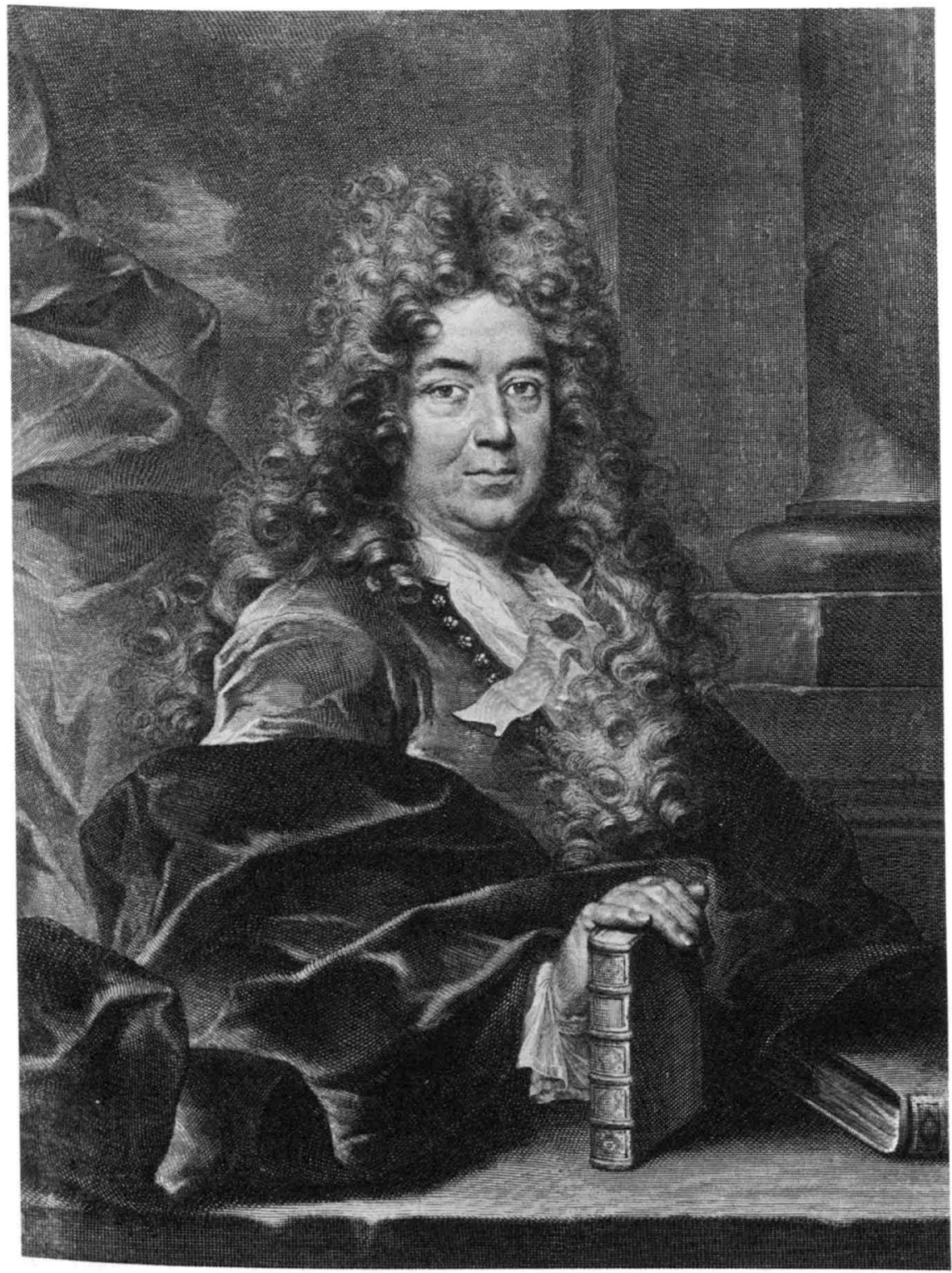

Charles Perrault. Engraving by Edelinck, after painting by Tortebat, 1694. Courtesy The Metropolitan Museum of Art, The Elisha Whittelsey Collection, The Elisha Whittelsey Fund, 1962 (62.650.211). 
nevertheless a man whom Colbert could trust. When Pierre's younger brother Charles acquired a favorable reputation as a poet by publishing two odes in praise of the King, Colbert had found the perfect candidate to help establish the Little Academy.

Charles Perrault epitomized Colbert's ideal of a subordinate in several ways. $\mathrm{He}$ was of bourgeois background, like Colbert himself, and had family connections to law and finance: his father, Pierre, had been a lawyer in the French Parliament, his eldest brother, Jean, was a lawyer, and his second eldest brother was the Receiver General. Perrault himself received a law degree, and although he had abandoned that career for the pursuit of poetry, he worked occasionally for his brother Pierre as a clerk and was familiar with matters of revenue and finance. At the same time, moreover, Perrault possessed the literary talent and sound artistic judgment that Colbert required for his purposes.

In his turn, Perrault undoubtedly profited from Colbert's patronage. He was not only appointed to be a founding member of the prestigious Little Academy, and later elected to join the distinguished ranks of the French Academy itself, but was also employed by Colbert as a personal assistant, in charge of a variety of artistic matters. In that capacity, Perrault achieved remarkable status both for himself and for other members of his family.

The greatest glory for the Perraults was won through the celebrated reconstruction and expansion of the Louvre. Mazarin had envisioned a project known as the "grand design," to unite the Louvre with the Tuileries Palace built by Catherine de Medici in the previous century, and to expand and embellish the existing structure. Work had begun as early as 1657 , with the purchase of building materials and the demolition of some of the many houses on the site which the new Louvre would occupy. In 1660, Mazarin approved a design to enlarge the palace submitted by the King's First Architect, Louis Le Vau. Despite Mazarin's death in that same year, the new construction was begun by Antoine de Ratabon, who was then Superintendent of Buildings.

The project was called to a halt by a political power struggle. In February of I66I, a major fire had destroyed part of the old building, and Charles Le Brun was placed in charge of its reconstruction. As King's First Painter, and the director of the Academy of Painting and Sculpture, Le Brun was a powerful figure; and it so happened that he disliked Ratabon. Le Brun used the influence of his Academy to support the advancement of Colbert, and Ratabon was eventually pressured to resign; Colbert then assumed the title of Superintendent of Buildings on I January 1664. Colbert, in his turn, disliked the architect Le Vau, who had profited handsomely from royal favor and was known for the excessive cost of his projects. The new superintendent made it known that the competition was reopened for the design of a new Louvre, despite the fact that the walls in some places had already reached the height of three meters.

The reconstruction of the Louvre is a fascinating episode in seventeenth-century 


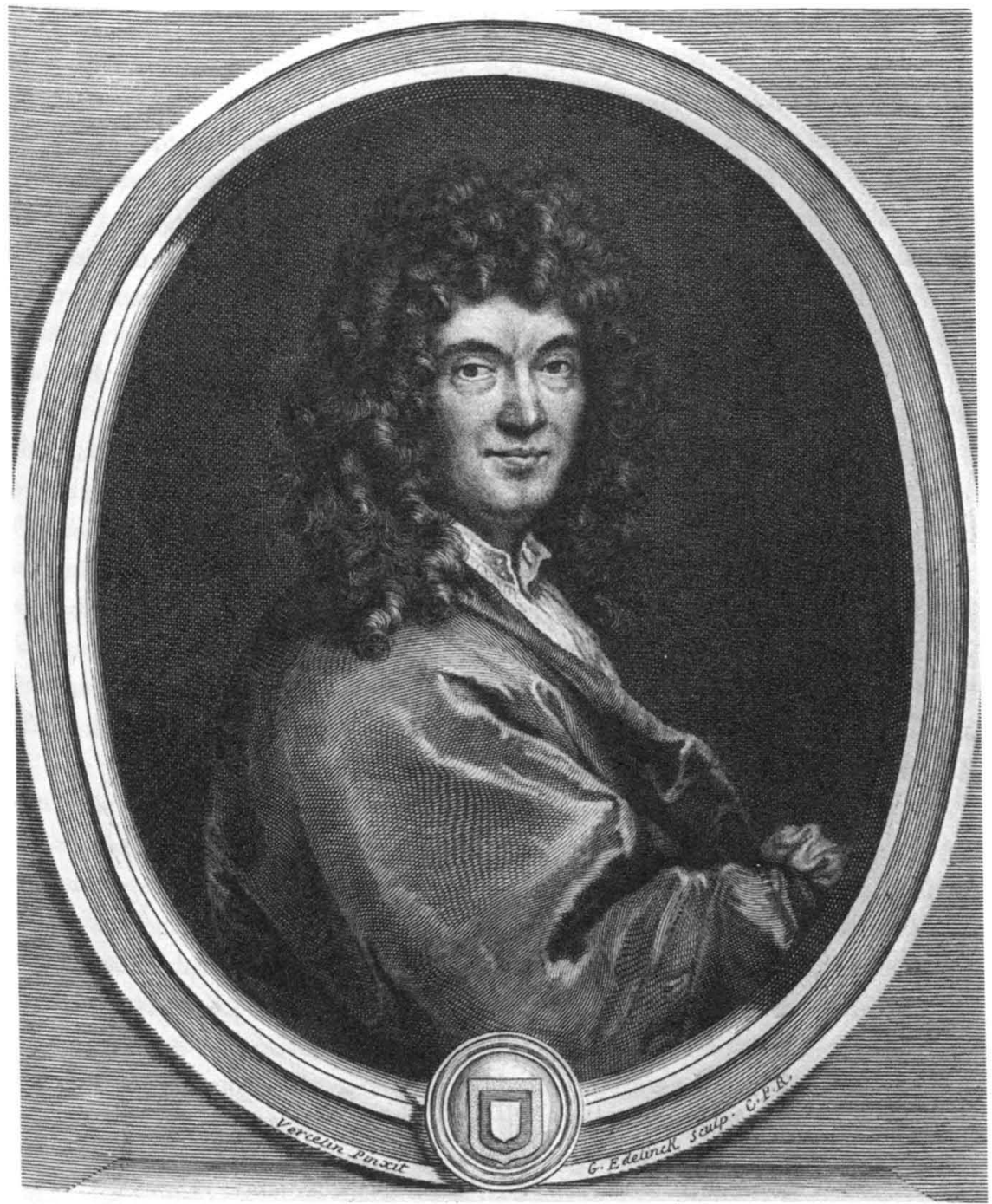

Claude Perrault. Engraving by Edelinck, after painting by Vercelin. Courtesy Library of Congress.

history, and one which has remained remarkably controversial over time. It was an event in which the role of artistic design as a manifestation of power was explicit, and in which a noble concept was nearly submerged by politics, rivalries, and selfinterest. Designs were submitted by every architect of note, including AntoineLéonor Houdin, François Mansart, and even François Le Vau, the First Architect's own brother; perhaps most importantly, a design was submitted by Claude Perrault, Charles's elder brother by fifteen years. Claude Perrault was not an architect by training or profession, but was a medical doctor, and therefore his entry into the 
competition outraged the Parisian architects, including of course Louis Le Vau. Claude's brother Charles, however, was Colbert's personal assistant, and in an excellent position to promote Claude's work.

Not content at first with any of the proposals made by the squabbling French architects, the King solicited designs from several prominent Italians, among whom was Gian Lorenzo Bernini, considered the foremost sculptor of his day and also the special protégé of Pope Alexander VII. After submitting several designs that received provisional approval, Bernini came to France in June 1665 and stayed through October, having accepted a token of the King's appreciation in the amount of thirty thousand livres, at a time when an artist's royal pension averaged fifteen hundred livres per year.

Two detailed yet contradictory accounts of Bernini's visit have been left to us: one is by Perrault, who here in his Memoirs admits to a degree of scheming in order to discredit Bernini's design, but nevertheless defends the integrity of his brother's talent; and the other is by the Sieur de Chantelou, a fervent admirer and friend of Bernini, whose diary portrays the Italian as a naive genius outmaneuvered by the unscrupulous French. The end result, however, was that after the expenditure of more than one hundred thousand livres on his behalf, and two more years of infighting among his rivals, Bernini's design was abandoned in favor of the colonnade attributed to Perrault.

The simple fact is that Bernini was sabotaged by his own arrogance, by his plan's enormous scale and lack of attention to practicalities, and by the disregard he evinced for the palace's symbolic purpose. The sixty-seven-year-old Bernini, accustomed to the adulation of popes, had been publicly disrespectful of the young King's taste, and had snubbed the members of the Royal Academy of Painting and Sculpture. Bernini also envisioned changes so extensive that it would have been more expedient to demolish the original structure. The fantastic cost of implementing these drastic changes was unattractive to a king whose armies were undergoing expansion and were engaged in numerous military campaigns in 1665 and 1666 . Such destruction would also undermine the myth of dynastic kingship, according to which the reign of Louis represented a culmination of many generations of divinely ordained rule. The King's sentiments were clear on this issue a few years later, when during the reconstruction of Versailles he would vehemently oppose destroying the original foundations of the hunting lodge built by his father.

Furthermore, some of the changes were undesirable. Bernini was more renowned as a designer of theatrical sets and church interiors than as a builder of actual residences. Chantelou's diary recounts a conversation in which Colbert told him:

The design of the Cavaliere Bernini, though beautiful and noble, was nevertheless so ill conceived for the convenience of the King and of his apartment in the Louvre that with an 
expenditure of ten million [livres], [the King] was left as cramped in the place he was to occupy in the Louvre as he would be without making that expenditure. ${ }^{2}$

Perhaps most importantly, however, Bernini did not comprehend that the Louvre required an outward show of magnificence. The modified design that had finally been agreed upon followed the Italian style in placing a complex of inner courtyards and galleries behind a massive, sober outer wall. These intimate courtyards were intended for the secluded pleasure of the monarch, but aside from the fact that the Parisian climate is not as well adapted to the open-air concept, Bernini failed to grasp that private comfort would willingly be sacrificed to public resplendence.

In I665, Colbert ordered a council to be formed of Le Vau, Le Brun, and Mansart; after Mansart's death in 1666, a new council was formed, and in April of 1667 it included Le Vau, Le Brun, and Claude Perrault. Two designs were presented for the King's approval, and in an order of 14 May 1667, Louis XIV selected Perrault's colonnade. This design, which called for the embellishment rather than the destruction of the existing palace, appealed both to the King's dynastic loyalties and to Colbert's pragmatism; and the design itself, with free-standing, weight-bearing columns, has come to be recognized as a masterpiece of the seventeenth-century classical style.

The question of attribution, however, has remained a contested issue for more than three hundred years. The significance of the project was such that nearly every major French artist and architect sought to receive credit for his participation, and many of their designs did in fact show similarities to the final plan that was executed. Restricted by the conventions of what was regarded as suitable for palatial architecture, however, the designs that survive can be seen to share numerous overlapping features, such as columns and statuary niches, that cannot be considered original to any single architect's imagination. Several modern scholars who have examined the early plans have concluded that the Louvre colonnade was in fact inspired by the work of Le Vau, Le Brun, or Le Vau's student François d'Orbay. ${ }^{3}$ Strong partisanship is also evident in contemporary records, such as the History and Research on Antiquities of the City of Paris by Henri Sauval, who died in 1676; Sauval's account, which would not be published until 1724 , stated the following:

These great works were begun in 1667 and brought to the state in which one sees them now in 1670 by the care and according to the designs of Louis Le Vau . . . François d'Orbai [sic], his student, contributed no small amount to the perfection of this beautiful work, and it 264.

2. Journal du voyage du Cavalier Bernin en France, ed. Lalanne (Paris: Gazette des Beaux-Arts, 1885), p.
64 .

3. In Bibliography, see T. Sauvel (1964) and M. Whitely and A. Braham (1964) for Le Vau; R. Berger (1960) for Le Brun; and A. Laprade, N. Bourdel, and J. Lafond (1960) for d'Orbay. 
is to these two excellent Architects that one must attribute all the glory of the design, and of the execution of this superb edifice, despite all that has been published to the contrary. 4

Nearly twenty-five years later, in 1694, François d'Orbay asserted that the Louvre design truly belonged to himself and to Le Vau, and he claimed to have documentary proof in his possession, yet no such papers were made public before d'Orbay's death. What might have been perhaps the only conclusive evidence, the sheaf of Claude's original designs, was lost forever in the I87I burning of the King's Library in the Louvre.

Yet despite his lack of previous architectural accomplishments, and the universal assumption that his brother had exerted undue influence, there is no reason why Claude Perrault could not have been the design's author. No doubt Claude's design would not have been brought to anyone's attention without his brother's involvement, but although rivals and enemies would charge that the affair was dishonestly maneuvered, what Charles Perrault did was no more than standard practice in his time. Personal and political influence was an accepted factor in seventeenth-century professional life; even among the rival architects, there were connections between Le Vau and his student d'Orbay, who also happened to be his son-in-law, and between François Mansart and his nephew, Jules Hardouin-Mansart, that in no way diminished their artistic reputations.

There is also the indisputable fact that Claude Perrault was publicly acknowledged as the author of the design during his lifetime and was subsequently chosen as the architect of two major projects: the Paris Observatory, which still stands south of the Luxembourg Gardens, and the now-demolished Arch of Triumph of the Porte Saint Antoine, a major city gate east of the Louvre. In the opinion of J.-A. Piganiol de la Force, born in 1673 and the author of the Historical Description of the City of Paris:

It would have been great impudence for Charles Perrault to attribute to his brother works which King Louis XIV and Monsieur Colbert would have known for themselves to be by Le Vau. Moreover, why did d'Orbay wait for the death of Claude Perrault to bring the issue to light? It was during his lifetime that it ought to have been said, and proven that he was enjoying a fame which rightly belonged to another. 5

There may have been an element of reticence on the part of many individuals to criticize a man whose brother was an intimate associate of the most powerful and feared minister in France; yet even after the death of Colbert, whom Claude survived

4. Histoire et recherches des antiquités de la ville de Paris (Paris: Moette et Chardon, 1724), 2:62.

5. Description historique de la ville de Paris et de ses environs, nouvelle édition augmentée (Paris: Desprez, 1765), 2:25I. 
by five years, there was no accusation of plagiarism. Even Antoine Arnauld, the great Jansenist theologian, came to Claude's defense in a letter of 1694 :

It is said, according to the word of a famous architect [d'Orbay], that the façade of the Louvre is not by [Claude Perrault], and that neither the Arch of Triumph nor the Observatory are the work of a doctor of the Faculty. This does not appear to me to have any believability, far from being true. . . . I do not think moreover that it is permissible to take away from a worthy man, upon hearsay, the honor of having done these works. ${ }^{6}$

The connection between his brother and Colbert had made Claude's work immediately suspect, but his reputation survived to become enshrined in a subsequent generation by the naming of a small street in his honor just east of the celebrated colonnade. The price of success for Charles Perrault, however, was to be a heavier one. As he advanced in the confidence of Colbert, his talent became increasingly belittled in the minds of his literary colleagues, and he became the target of more than the usual degree of resentment.

At Colbert's instigation, though no doubt this wish was in accord with his private ambitions, Perrault was presented for membership in the French Academy. He was not elected, however, until his third attempt, in 1671. Elections to the Academy were in effect political appointments, and according to the Memoirs, Perrault's rejections were due to Colbert's having promised those seats to other men. Nevertheless, it is not unreasonable to suppose that many Academicians met Perrault's election with considerable resistance.

Once admitted, Perrault became one of the Academy's most assiduous members, attending virtually every session for over thirty years. His publications in the early years were sparse, owing no doubt to his heavy administrative responsibilities. Nevertheless, his literary efforts were generally respected, and occasionally praised in terms which suggest sincere admiration. In September 1677, Colbert entertained the members of the French Academy at his mansion in Sceaux, and according to the literary journal Le Mercure Galant (Gallant Mercury):

Monsieur Perrault, supervisor of buildings, spoke last. He only recited a few stanzas, but they reawoke everyone's attention. The frequent applause that they received was an incontestable proof of their beauty. There is no reason to be surprised at this. Monsieur Perrault has what is called a mind of good taste, which never indulges in false brilliance. He writes, and knows how one should write. He is knowledgeable about all the finer things, and his works have always had a great success. It could be wished that we had more of them, but his duties do not allow him to work.?

6. Letter to Charles Perrault of June/July 1694, in Oeuvres, (Paris: D'Arnay et Cie., 1776), 4:58.

7. October 1677, p. 125. 
Perrault's advancement had continued as Colbert enlarged the spheres of his authority and was forced to delegate some of his responsibilities. Colbert had become Secretary of State for the Navy in 1669, and when Louis XIV declared war on Holland in 1672, Perrault was given the newly created post of Controller General of the King's Buildings, Gardens, Arts, and Manufactories. As a reflection of the esteem in which he was held, Perrault was granted this position on merit, without having to purchase the office, although when he resigned ten years later it was bought from him according to standard practice. During this period, Perrault's role was to handle administrative matters such as construction equipment and salaries and to advise Colbert on issues of major significance, over which the minister retained decision-making authority.

After nearly twenty years of service to Colbert, however, Perrault's political career foundered upon the minister's ill humor and family ambitions. Colbert's fourth son, the Marquis d'Ormoy, had been granted his father's title as Superintendent of Buildings at the age of nine, in the same year that Perrault's new title of Controller General had been created, and in $\mathbf{6 8 2}$ the young man was nineteen. It was decided that he would assume his formal responsibilities, and Perrault was forced to resign. It may have brought some satisfaction to Perrault that his successor was so incompetent that in the following year, when Colbert died, d'Ormoy was ordered by the King to sell his charge on the very day of his father's death. For Perrault, however, it was too late for rehabilitation, and he found himself without a position or a patron at the age of fifty-four.

In a sense, the dismissal from public service granted Perrault the freedom to pursue that which was his first love, and which had originally brought him to Colbert's attention: his poetry. Writing was also his defense against those who had believed that the only justification for his presence in the Academy was to serve as Colbert's spy. The time had come at last, however, when his enemies could attack him with impunity, and among the first was the minister Louvois, who was the son of Michel Le Tellier, an older-generation Academician who had greatly resented the presence of Perrault. Though appointments to the French Academy were for life, and there was no way to deprive Perrault of his literary status as well as his political influence, Louvois could and did exclude Perrault from the Little Academy which he had helped to found. Louvois even claimed that Perrault had never been more than a secretary for the group, and in the registers of the Academy published after Perrault's death, he was only listed as an official member for three years, from 1679 to 1682 . There is enough documentation of Perrault's creative contributions, however, to verify that he had indeed been an active participant since the very beginning, and this dismissal was undoubtedly one of the bitterest blows in his lengthy career.

In view of Perrault's newly precarious status, it is not surprising that his subsequent poetry was dominated by themes that even his severest critics would find difficult to condemn. In I685, Louis XIV revoked the Edict of Nantes, which had 
previously guaranteed limited freedom of religion to Protestants, and before the end of the year Perrault had published an Ode to New Converts. This work initiated a series of "Christian poems," which included Saint Paulin, Bishop of Nôle (1686), The Triumph of Sainte Geneviève (1694), and Adam, or the Creation of Man, His Fall and His Reparation (1697).

The poem of Saint Paulin was the most ambitious, and unfortunately the most illfated of these efforts. It was a long poem of 106 pages, in the epic-heroic style that was commonly admired as the most noble of all literary genres. A similar, more grandiose work had previously been published by his colleague Jean Chapelain, whose epic poem in twelve cantos on Joan of Arc (La Pucelle, ou la France délivrée [The Maid, or France Delivered], I656) had been heavily criticized for its turgid style and excessive length. Perrault's much shorter poem, also recounting the martyrdom of a French saint, fared no better. As he did not enjoy the sterling reputation that had protected Chapelain to some degree, criticism soon degenerated into open mockery. Foremost among Perrault's attackers was Nicolas Boileau, the famous satirist and Academician, who had been hostile to both Charles and Claude for more than a decade, and who made disparaging references in his own poems and epigrams to "Monsieur P . . ." and to "the author of Saint Paulin."8

At the beginning of the following year, 1687, the King underwent an operation for a fistula, and in celebration of his recovery the Academy held a special session on 27 January. Once again Perrault attempted an appeasement of his critics and a vindication of his talent in the form of a long poem entitled "The Age of Louis the Great." The aim of this poem was to compare modern society favorably with ancient times, noting the advancement of civilization and the flourishing of the arts under Louis $\mathrm{XIV}$, and thereby flattering both the King and Perrault's own contemporaries.

Despite the poem's innocuous intent and laudatory style, it generated immediate controversy, which Perrault may have anticipated to some degree, as witnessed by the fact that he did not read it aloud himself but had it delivered by his friend the Abbé de Lavau. His critics chose to interpret the poem not as an expression of flattery of modern writers, but as a denunciation of the great authors of antiquity such as Homer and Virgil, and of the classical masterpieces that were considered in the seventeenth century to represent a pinnacle of literary achievement.

The Academy was polarized into two camps, certain members supporting the socalled Moderns, and endorsing the progress of civilization, and others supporting the Ancients, and defending the sublimity of classical models. And Perrault was thrust into the position of serving as the leader and spokesman of the Moderns, a role that was ultimately to provide a focal point for the most important writings of his career.

No literary quarrel, sparked by such an insignificant cause as the reading of a single poem, has ever had such widespread repercussions as the Quarrel of the Ancients and

8. In Epigrams of 1692 and 1693 , and in the Ode on the Taking of Namur, 1693. 


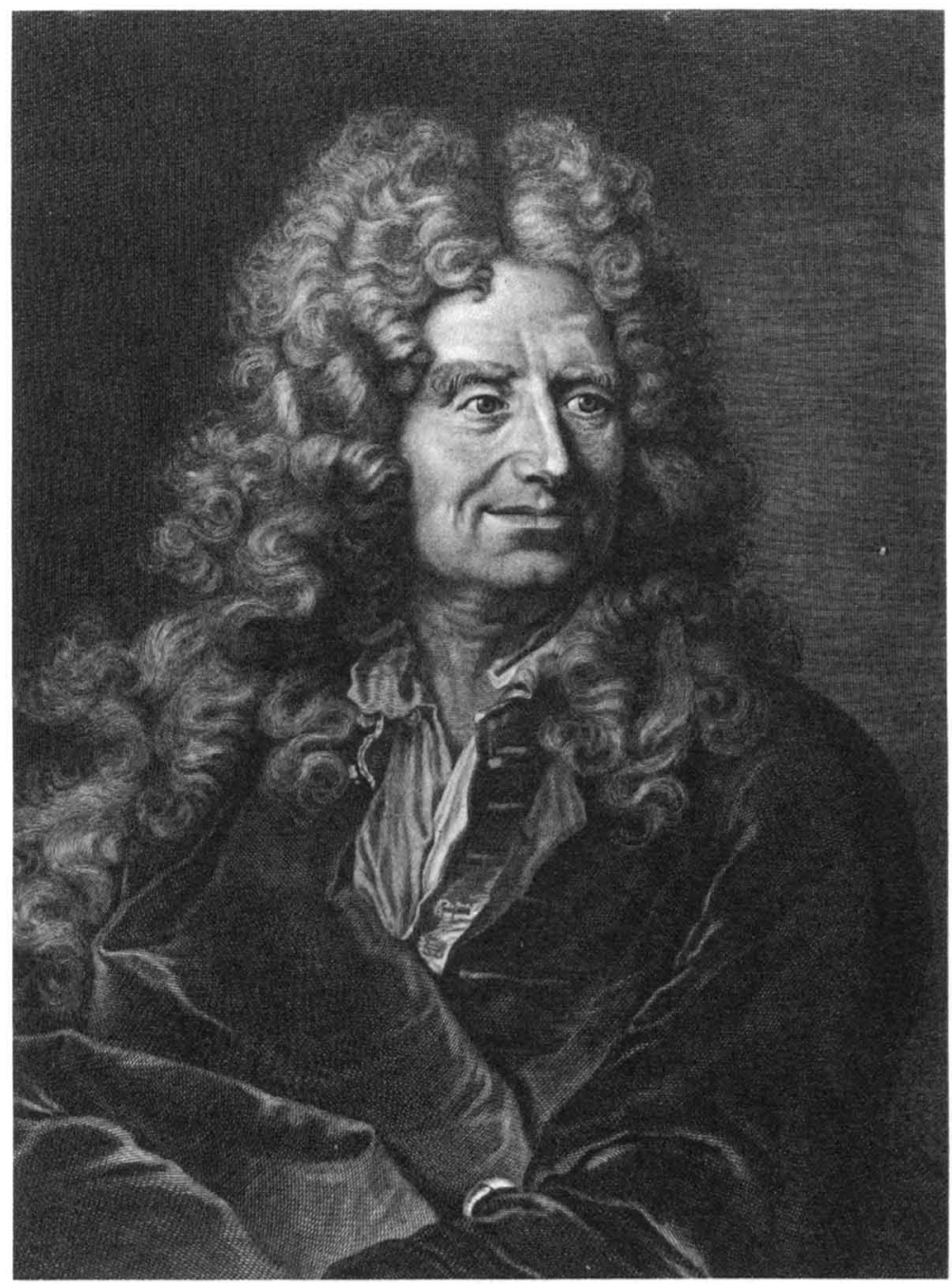

Nicolas Boileau. Engraving by Chéreau, after painting by Rigault. Courtesy Bibliothèque Nationale.

Moderns. It is doubtful that Perrault himself could have anticipated that this debate would provide intellectual fodder for the revolutions of the eighteenth century, by justifying the abolition of outdated social systems; or that it would contribute to the nineteenth-century Romantic revolution, by asserting the superior sensibility of the contemporary spirit over the mores of ages past.

The Quarrel had an entirely different meaning for Perrault himself, its instigator. It was to be the final stage in his struggle for legitimacy, in a field where his credibility had been undermined from the very first. If he were to earn or retrieve the 
respect of his colleagues, Perrault would have to persuade them that his views were neither the result of thoughtlessness and ignorance, nor an expression of resentment on the part of an inferior author towards the heroic models of antiquity.

He set out to accomplish this by producing the first volume, in October 1688, of the Parallel of the Ancients and Moderns, a series of dialogues in which an imaginary "Président" (judge or councilman), an "Abbé" (abbot or priest with no ecclesiastical duty), and a "Chevalier" (titled gentleman) discuss the relative accomplishments of ancient times and seventeenth-century France. The "Président" generally upholds the Ancients with vehemently narrow-minded arguments, which the "Abbé" counters in a more moderate tone, and with carefully reasoned examples supporting Perrault's own views; the "Chevalier," meanwhile, is a passive, presumably objective observer who never fails to agree in the end with the "Abbé."

In subsequent volumes of the Parallel, published in 1690, 1692, and 1697, Perrault reinforced his position by broadening his comparisons to include such fields as geography, astronomy, navigation, and medicine, in which the superiority of the Moderns was difficult to contest. By representing the arts as merely one aspect of a general cultural advancement, and by offering the debate in the entertaining format of dialogue, Perrault succeeded in creating a persuasive manifesto of the modernist view, more than twelve hundred pages in length, that would effectively change the thinking of the generations to follow.

His opponents were not of course silenced by the Parallel, but because his arguments were so convincingly mounted, the attacks were largely personal in nature. In the Parallel's second volume, published in 1690, Perrault had offered his own translations of several classical authors, so that the reader might compare their eloquence to the presumably comparable gifts of several contemporary writers whom he also cited. This led Boileau to produce the following epigram in 1692:

How is it that Cicero, Plato, Virgil, Homer, and all these great authors whom the universe reveres, when translated in your writings appear to us to be so stupid? P . . . it is because in lending to these sublime minds your manner of speaking, your crudenesses, your rhymes, you make them all into P... s.9

No defense can be effective against humor, and certainly Perrault's reputation, in addition to his pride, was damaged by Boileau's attempt to turn him into a figure of ridicule. Far from being deterred, however, he not only continued to work on the Parallel but undertook a new avenue of approach in advancing his cause. In 1696, he published Illustrious Men who have Lived in Our Century, with their Naturalistic Portraits, giving brief biographies of fifty important statesmen, theologians, scientists, and artists of seventeenth-century France. A second volume followed in I700, containing

9. In the original poem, the rhyme scheme makes it clear that the deleted word is Perraults. 
an additional fifty portraits. ${ }^{10}$ The selection of individuals described, all of whom were deceased, included prominent political figures, both at court and in the French Academy, whose friends and relatives continued to exercise an important influence. Among the writers and artists, some individuals such as Malherbe and Corneille, whose talent was beyond dispute, were flanked by less revered but highly popular names such as Quinault and Benserade. Perrault's choices were clearly intended to convince the reader of the notion that the age of Louis the Great was indeed blessed with men of extraordinary talent, while at the same time potential critics would hesitate to disagree with his eulogies of those whose names still exerted political power even after their death. It is also not accidental that since the decision was made to exclude living persons, Perrault's adversaries Boileau and the famous tragedian Jean Racine were absent from the first volume of Illustrious Men, although after Racine's death in 1699, Perrault was forgiving enough to include him in Volume Two.

During this period, Perrault continued to produce a steady flow of circumstantial poetry, often glorifying the monarch or the royal family, as in his Odes to the Dauphin, the King's heir (1688), and to the King himself (1693). Once again, his choice of subject inhibited potential criticism, although it undoubtedly curtailed the freedom of his poetic expression, and contributed to the very reputation his enemies wished to promulgate, of Perrault as a poet of limited imagination and mediocre talent.

Perhaps in reaction to this self-imposed restraint, Perrault pursued a consistent interest in fables and tales of a light vein. The fables of La Fontaine, of which the first books had appeared in 1668 , became immediately popular and had inspired numerous imitations of the genre. Perrault himself wrote an unpublished verse fable in 1674, "The Crow Cured by the Stork." In this tale of a kindly stork who twice saves the life of an ungrateful crow, the characters are only thinly disguised portraits of Claude Perrault and Boileau, who claimed to have once been nearly killed by Claude's medical treatment and who portrayed him in The Art of Poetry of I674 as a "doctorassassin."

In his Collection of Diverse Works in Prose and in Verse of 1675 , Perrault had also published "The Labyrinth of Versailles," short fables with gallant verse morals that were inspired by a group of Versailles statues of characters from Aesop's Tales. Then, over a decade later, he published a French translation of his friend Charles Du Périer's Latin poem, The Sick Lion, the Wolf, and the Fox (1686), and in 1699 he would produce a translation of fables by the Italian author Gabriele Faerno.

The outbreak of the Quarrel of the Ancients and Moderns in 1687 gave a new

Io. Y. Bézard, in Les Bégon (Clichy: Dupont, 1932), suggested that some of the portraits were written by Michel Bégon, a second cousin of Colbert's wife, and that the work represents a collaboration for which it was agreed that Perrault would take full credit.

II. The text of this fable was printed by Philippe-Louis Joly in his Remarques critiques sur le dictionnaire de Bayle of 1748 (Paris: H. Guérin), pp. 632-33. 
direction to this interest in fables. La Fontaine, who was a partisan of the Ancients, had published several books of Contes (Tales, giving elegantly rhymed versions of a variety of humorous and often bawdy stories, many of which were derived from Latin sources. Ever in search of new arguments to support the Moderns' cause, Perrault composed a poem based upon a story by a relatively recent author, the fourteenth-century Boccaccio, in which a more positive model of virtue was portrayed. Patient Griselda was a long-suffering peasant girl whose suspicious husband forced her to endure numerous tests of loyalty, to which she submitted with Christian resignation. In the end, her fortitude was generously rewarded. In Perrault's version, the characters were elevated in social rank and made to speak in the language of the seventeenth-century court, and Christian virtue was given a greater emphasis. This project was taken quite seriously by him, and on 25 August 169I, his friend the Abbé de Lavau read aloud The Marquise of Salusses or the Patience of Griselidis before the French Academy.

Reaction to the poem was generally favorable, and the Mercure Galant reported in its issue of the following month that "the lively descriptions with which this poem is filled attracted much applause, and everyone left that meeting greatly satisfied." I2 This initial success encouraged Perrault to compose two more verse tales, The Ridiculous Wishes (which despite its classical origins was recast as a tale of French peasants) and Peau d'Âne (Donkey-Skin), both of which appeared in 1693 and were reprinted together with Griselidis in a collection of 1694. In the first tale, a husband and wife are given three wishes by Jupiter, and after squandering the second on an impatient curse that attaches a sausage to the end of his wife's nose, the husband is forced to use the third wish to restore everything to its original impoverished order. Donkey-Skin is the story of a princess who is forced to endure various humiliations, including the wearing of a donkey-skin and a threatened incestuous marriage with her father, before her eventual marriage to a prince. This tale was drawn from popular "modern" culture, as two similar versions had been written by the Italian writers Straparola and Basile. ${ }^{13}$

The new tales were treated much less kindly than the first, receiving no mention in the Mercure Galant; furthermore, they provoked more damaging ridicule from Boileau. The humble peasant settings and elements of magic that would no doubt have been perfectly acceptable in a tale by La Fontaine were found to be undignified and demeaning in a work by Perrault. In an epigram of I693, Boileau wrote that "if you wish to find the model of perfect boredom, do not seek . . . a poet comparable to the inimitable author of Donkey-Skin put into verse." He also said in a letter to Antoine Arnauld, who was seeking to reconcile Boileau and Perrault:

\footnotetext{
I2. September I69I, p. 23.

I3. Giovanni Francesco Straparola, "Doralice," in Le Piacevoli Notti (I555), and Giovanni Battista Basile, "L'Orza," in Il Pentamerone (posthumously, 1634-1636).
} 
Here is a list of the works you wish me to admire. I will be much mistaken if you have ever read any one of them. The tale of Donkey-Skin and the story of the woman with the sausage nose, put in verse by Monsieur Perrault of the French Academy . . . Parallel of the Ancients and Moderns, where we see poetry carried to its greatest height of perfection in the operas of Monsieur Quinault . . . I laugh, monsieur, in writing this list for you, and I think that you will have difficulty preventing yourself from laughing also while reading it. ${ }^{14}$

For Perrault, however, the tales served a serious and legitimate purpose. In the preface to the verse tales' third edition in 1695 , he stated clearly that "I believe that my Fables are more worthy of being recounted than most of the ancients' Tales . . . which were created only to please, without regard for sound morals, which they greatly neglected." He praised instead the modern imagination of his more recent forebears: "they did not tell [their tales] with the elegance and the pleasing touches with which the Greeks and Romans embellished their Fables; but they always took great care that their tales should include a praiseworthy and instructive moral." is On moral grounds, therefore, these products of what today would be termed folklore represented yet another example of modern superiority. It was a natural step further to present more examples of these moral tales, taken not from Italian writers but from the truly "French" stories that children heard from their parents and nursemaids, and shaped by Perrault into the now-celebrated fairy tales.

The Histories or Tales of Past Times, with Morals first appeared in 1695, in a beautifully hand-lettered presentation manuscript with watercolor illustrations, dedicated to the King's niece, the nineteen-year-old princess Élisabeth-Charlotte d'Orléans. The choice of such a distinguished recipient, who was clearly an adult by contemporary standards, was an indication of Perrault's pride in his accomplishment. To deflect potential criticism, the five tales included in the manuscript were presented under the name of his youngest son Pierre, who was then seventeen years old; according to contemporary evidence, however, Perrault's acquaintances did not take this conceit seriously.

One of the tales, "La Belle au Bois Dormant" ("The Beauty Sleeping in the Woods" ["Sleeping Beauty"]) was published in the Mercure Galant of February 1696, this time anonymously. It was well received, earning laudatory mention in a subsequent issue of August/September as having "a refined and delicate style, [and] quite novel expressions." 16 Then in 1697 Perrault published the complete text of eight prose tales, which in their original order were as follows: "La Belle au Bois Dormant," "Le Petit Chaperon Rouge" ("Little Red Riding Hood"), "La Barbe Bleue" ("Bluebeard"), "Le Maître Chat ou le Chat Botté" ("The Master Cat or the

14. Letter of June 1694, in Oeuvres, ed. Mongrédien (Paris: Garnier, 1961), p. 346.

I5. Reprinted in Contes, ed. J.-P. Collinet (Saint-Amand: Gallimard, 198I), pp. 50-5I.

I6. August/September 1696, p. 74. 
Booted Cat" ["Puss in Boots"]), "Les Fées" ("The Fairies" ["Diamonds and Toads"]), "Cendrillon ou la Petite Pantoufle de Verre" ("Cinderella or the Little Glass Slipper"), "Riquet à la Houppe" ("Ricky with the Tuft"), and "Le Petit Poucet" ("Little Thumbkin" ["Tom Thumb"]).

When the full collection appeared, however, there was no mention of it in the Mercure Galant, nor was it ever cited in posthumous listings of Perrault's work. By this time, Boileau and Perrault had been publicly reconciled, but his earlier jibe at the "story of the woman with the sausage nose, by Monsieur Perrault of the French Academy" had had such impact that Perrault's nursery tales, in which peasant men and women figured as heroes, were greeted by the Academy with official silence.

If Perrault's colleagues viewed the tales as being beneath his Academic dignity, then certainly the public's reception of them throughout later history was no different, though for an opposite reason. The plots, characters, and charming narrative style that so captured the popular imagination were commonly believed to have been the polished product of centuries of oral tradition, having no true author. Virtually any French-speaking child today can identify the "contes de Perrault," Perrault's Tales. Perrault himself, however, is perceived merely as a vague and benevolent father figure, much like the traditional Mother Goose. He is presumed to have been no more than an old man, recalling stories from his youth, and writing them down to amuse his children or grandchildren. In this role, the author is not an inventive genius, possessed of an individual personality and intent, but simply a vehicle or outlet for the collective voice of folk culture. That sentimental view is of course far from the truth. Perrault's actual tales were
cleverly pieced together from a variety of models and were given elements of humor and language alluding to seventeenth-century bourgeois and court society that would have been foreign to a peasant's tale. One need only recall Cinderella's liveried footmen, or the talking cat wearing the boots of a musketeer (as he appeared in the original title illustration of 1695), or the salon of mirrors in which the Sleeping Beauty was wed, reminiscent of the Galérie des Glaces at Versailles. The wicked fairy in Sleeping Beauty was not inherently evil, but simply offended by a violation of etiquette, having been excluded from an important banquet; Bluebeard's wife married him strictly for his money, and in the end was a happy widow who purchased high army ranks for her brothers and, with a large dowry, a new husband for herself; Little Thumbkin used his seven-league boots to carry dispatches to the army and ferry letters back and forth between married women and their lovers. Each tale was also accompanied by one or two verse morals, composed in such precious, sophisticated language that most modern publishers of the tales eliminate them entirely, considering them unsuitable for children-as indeed they are. Although children were certainly not excluded from Perrault's intended readership, the tales' conception and presentation were aimed at a far different audience: his colleagues in the French Academy. It is an irony of literary history that modern scholarship has at last 
acknowledged the tales' importance as a serious work of literature, today taking the very attitude that Perrault had hoped for in vain three hundred years before.

Although the tales were not destined to be received as proof of modern superiority, there were other ways in which Perrault continued to labor for his cause. In 1694, the same year in which the verse tales were published, Boileau wrote a satire against women to which Perrault took violent exception. His reply, entitled L'Apologie des Femmes (The Apology [Defense] of Women) included the following remarks in its preface:

The author of the Satire [Boileau] always acts according to a principle which is very false and capable of making one commit many mistakes. He imagines that one cannot err in following the example of the Ancients; and because Horace and Juvenal declaimed against women in a scandalous manner, and in terms which offend modesty, he has persuaded himself that he has a right to do the same thing. ${ }^{17}$

The last volume of the massive Parallel of the Ancients and Moderns appeared in 1697, the same year as the Tales. At that time, however, a major crisis occurred in Perrault's personal life. On 6 April 1697, his youngest son, Pierre, then seventeen years old, engaged in a duel with a neighbor, Guillaume Caulle, also only sixteen or seventeen years old. Caulle was killed, and Pierre was arrested for murder and imprisoned in the Châtelet fortress. He was released in March by special dispensation, and an indemnity of two thousand livres was paid to the boy's mother. Pierre was allowed to enter the army, a measure perhaps intended to discipline his behavior; instead, it brought him an early death on 2 March 1700 , at the age of twenty-two.

This was to be the final tragedy in Perrault's family life. His wife had died after only seven years of marriage, his sister did not live past childhood, and none of his four brothers were to survive him. The brother closest to him in age, Nicolas, had died in 1662 at the age of thirty-eight, and his eldest brother, Jean, had also perished young, of a fever resulting from a carriage accident in October 1669.

After his son's death, Perrault continued to write, publishing the second volume of the Illustrious Men in I700. He was now seventy-two years old, however, and there would be no more ambitious undertakings in defense of the Moderns. Instead, he returned to the kind of courtly poetry upon which his literary career had been founded. In an interesting parallel to his first odes, dedicated to Louis XIV, his last two odes were for King Philip V of Spain (I7OI), a grandson of the King, and King Charles XII of Sweden (1702), whose father had been a strong ally of France in the war against Holland. He also returned to the fable, reading aloud to the Academy in 1702 a mythological fantasy he had published nine years earlier, The Reed of the New World, or the Sugar Cane.

In private, however, he devoted himself to a manuscript of collected thoughts on

17. 1694, p. ii (unnumbered in original edition). 
various subjects, which he had begun in 1694 and was still composing in 1702 . This collection of very brief essays, perhaps modeled after the Thoughts of Blaise Pascal, was entitled Christian Thoughts, but its topics ranged from religion to physics, poetry, architecture, and fine arts. Perrault was also at work upon a manuscript in which many of his personal frustrations and sorrows would be expressed: the Memoirs.

It is impossible to know whether Perrault intended the Memoirs to be published. There are early references to "your uncles," identifying Perrault's children as his immediate audience; however, he offered nothing about his own parents, and very little of the anecdotal information about his upbringing or childhood experiences that would be natural to include in a family history. Instead, Perrault focused upon his career, offering observations on the various situations he had encountered and the individuals with whom he had dealt. In this sense, the Memoirs are more of a selfapology; they offer Perrault's side of the story, in defense against how he had been depicted by his enemies, and finally giving release to many of the thoughts that diplomacy had prevented him from expressing at the time of the actual events.

The Memoirs, like the Christian Thoughts, were left unfinished upon Perrault's death, which came upon him suddenly in 1703 . There was no gradual decline, as he continued to write and to attend assiduously the meetings of the French Academy. His last recorded attendance was on II April 1703; then, after a short illness, he died at home on the night of Is May. He was buried on I7 May in his parish church of SaintBenoit, where Claude had also been inhumed. The Mercure Galant ran a twenty-page obituary in the issue of May 1703 , and on 8 June, the Academy held a memorial service in his honor. Perrault's surviving son, Charles, was present, and Boileau wrote to a friend on 3 July that the young man "assured me that when he was dying, [Perrault] had entrusted him to express great civilities to me, and to assure me that he died my obedient servant." 18 These civilities were apparently lost upon Perrault's old rival, for in the same letter he proclaimed that "as regards Monsieur Perrault, I have not spoken to you of his death, because frankly I took no more interest in it than that which one takes in the death of any honest man." Boileau also jibed that one man had refused Perrault's vacant seat in the Academy for fear of having to make the obligatory eulogy of one's predecessor, and having to "praise the enemy of Cicero and Virgil."

Boileau's attitude was by no means universal, however. There were numerous expressions of public homage, including a eulogy by the Abbé Paul Tallemant. ${ }^{19}$ Significantly, another eulogy was offered by one of Perrault's long-standing opponents in the Quarrel, Anne Dacier. Madame Dacier, a respected translator of Homer and a passionate defender of the Ancients, made the following description of her former adversary:

18. Oeuvres complètes, ed. Adam (Paris: Gallimard, 1966), p. 675.

19. An abridged text of this eulogy is given in Appendix E. 
He had all the qualities that make up an honorable man and a good man. He was full of piety, probity, virtue; polite, modest, obliging, faithful to all the duties required by natural and acquired ties; and in an important job, at the side of one of the greatest ministers whom France has ever had and who honored him with his confidence, he never made use of his good favor for personal gain, but always used it for his friends. ${ }^{20}$

The contradictory impressions of Perrault provided by his own contemporaries reflect a quandary that has persisted more than three hundred years: who was the real Charles Perrault? Was he a manipulative schemer of mediocre abilities, or an unjustly accused, talented man of scrupulous integrity? The historical record can provide only proof that, owing no doubt to his position with Colbert, Perrault was a man who made enemies. He was responsible for frustrating the ambitions of a great number of persons associated with the creative arts, particularly in the Louvre affair, and his prominence in the French Academy and in the Academy of Inscriptions and Medals gave rise to enormous resentments.

Boileau was not the only contemporary to voice hostilities against Perrault. Racine, another writer who supported the cause of the Ancients, and who in I674 had mocked Perrault's views about theater in the preface to his play Iphigénie, wrote satirical couplets in I69I that ran in part: "Stubborn about his false system, Perrault the mutinous philosopher argued with extreme force, and coiffed by his contrariness, played the imp, to prove clearly himself that he understood neither Greek nor Latin ...." Antoine Furetière was another rival whose dislike of Perrault ran deep; impatient with the Academy's slow progress on its dictionary, Furetière prepared his own, but Perrault and others accused him of plagiarism and forced his exclusion from the Academy. Not surprisingly, his opinion of Perrault was harsh: "His half-capacity is not always useless to the Academy, because he takes it upon himself to consult his brother, who is a cleverer man than he, on the difficulties that he is not able to resolve. The unfortunate thing is that he forgets on the way half of what he has learned." 22

These vilifications had a profound influence on later historians, who perpetuated many of the innuendos about Perrault's lack of ability. For example, in the official History of the Royal Academy of Inscriptions and Letters published in 1719, sixteen years after Perrault's death, he is described not as a writer or poet, but as a "man in the confidence of Colbert, who held the pen [took notes], in order to be always in a position to report to Monsieur Colbert what had taken place." 23 And probably the most scathing denunciation of him ever published was written by P.-C.-F. Daunou, a nineteenth-century editor of Boileau's works, who said the following:

20. Cited in P. Bonnefon, "Les Dernières Années de Charles Perrault," Revue d'Histoire Littéraire de la France 13 (1906): 656-57.

21. Cited in A. Laprade, N. Bourdel, and J. Lafond, François d'Orbay (Paris: Vincent, Fréal et Compagnie, 1960), p. 43.

22. Ibid., p. 42, note 3 .

23. Histoire de l'Académie royale des inscriptions et belles-lettres (Amsterdam: n.p., 1719), 1:4-5. 
Academician without instruction, and rhymer of the lowest style, scarcely able to emulate his most clumsy colleagues, he knew no more than to be their protector, one of these low-grade Maecenases who promote mediocrity in order to appear superior to it . . and deprave literature by their wiles as much as they dishonor it by their writings. ${ }^{24}$

In sifting the truth from among all the accusations, the telling evidence must come not from partisan opinion but from Perrault's own work. The assessment of literary talent is highly subjective, but it is a fact that some of his poetry has been praised by later scholars and that his Tales have received accolades over the centuries as models of prose clarity, charm, and elegance. In terms of longevity and popularity, that particular work has had far greater success than anything ever written by all of his critics combined.

There are also some traits of character that may be discerned from the record of his accomplishments. He possessed a strong sense of family loyalty and protectiveness, particularly regarding his brother Claude, whom he eulogized in the Illustrious Men. Loyalty toward his colleagues was also evident in the Quarrel of the Ancients and Moderns, in which he continued to defend the abilities of writers such as Quinault and Chapelain despite ridicule. Tenacity was a trait that sustained him in nearly twenty years of devoted service to Colbert and saw him through the long years of the Quarrel and the production of the massive Parallel of the Ancients and Moderns. And regardless of whether or not his peers' resentments were justified, it took a special kind of courage for Perrault to continue so actively in the French Academy after Colbert's death, when he became an object of open attack. Perrault also had a dry humor that is one of the most appealing aspects of the Tales and gives several of his poems a gentle wit that contrasted sharply with Boileau's satirical destructiveness.

Some of Perrault's personal beliefs are reflected in his work as well. He demonstrated a consistent interest in Christian subjects, from his several poems about Biblical figures or saints to the unfinished manuscript of Christian Thoughts. Then, in his Apology of Women, he manifested sincere offense at the hostile caricatures of Boileau's satire and offered a strongly positive and respectful depiction of female virtues. Many of his writings display an affectionate attitude towards children and family life and a belief in the importance of moral and spiritual education.

Most importantly, there is evidence of Perrault's true character in the ability he possessed to communicate a sense of his own personality, through a variety of writings that lead us ultimately to the Memoirs. Even in its incomplete and unrevised although the reader may not choose to believe that everything he says is strictly factual, the manner in which he expresses his thoughts offers a different and more profound truth. The Memoirs were written to provide a record of what Perrault himself considered to be the most important events of his turbulent career, and of

24. Oeuvres complètes de Boileau-Despréaux (Paris: Peytieux, 1825), "Discours préliminaire," p. xix. 
He had all the qualities that make up an honorable man and a good man. He was full of piety, probity, virtue; polite, modest, obliging, faithful to all the duties required by natural and acquired ties; and in an important job, at the side of one of the greatest ministers whom France has ever had and who honored him with his confidence, he never made use of his good favor for personal gain, but always used it for his friends. ${ }^{20}$

The contradictory impressions of Perrault provided by his own contemporaries reflect a quandary that has persisted more than three hundred years: who was the real Charles Perrault? Was he a manipulative schemer of mediocre abilities, or an unjustly accused, talented man of scrupulous integrity? The historical record can provide only proof that, owing no doubt to his position with Colbert, Perrault was a man who made enemies. He was responsible for frustrating the ambitions of a great number of persons associated with the creative arts, particularly in the Louvre affair, and his prominence in the French Academy and in the Academy of Inscriptions and Medals gave rise to enormous resentments.

Boileau was not the only contemporary to voice hostilities against Perrault. Racine, another writer who supported the cause of the Ancients, and who in 1674 had mocked Perrault's views about theater in the preface to his play Iphigénie, wrote satirical couplets in I69I that ran in part: "Stubborn about his false system, Perrault the mutinous philosopher argued with extreme force, and coiffed by his contrariness, played the imp, to prove clearly himself that he understood neither Greek nor Latin ...."21 Antoine Furetière was another rival whose dislike of Perrault ran deep; impatient with the Academy's slow progress on its dictionary, Furetière prepared his own, but Perrault and others accused him of plagiarism and forced his exclusion from the Academy. Not surprisingly, his opinion of Perrault was harsh: "His half-capacity is not always useless to the Academy, because he takes it upon himself to consult his brother, who is a cleverer man than he, on the difficulties that he is not able to resolve. The unfortunate thing is that he forgets on the way half of what he has learned." 22

These vilifications had a profound influence on later historians, who perpetuated many of the innuendos about Perrault's lack of ability. For example, in the official History of the Royal Academy of Inscriptions and Letters published in 1719, sixteen years after Perrault's death, he is described not as a writer or poet, but as a "man in the confidence of Colbert, who held the pen [took notes], in order to be always in a position to report to Monsieur Colbert what had taken place." 23 And probably the most scathing denunciation of him ever published was written by P.-C.-F. Daunou, a nineteenth-century editor of Boileau's works, who said the following:

20. Cited in P. Bonnefon, "Les Dernières Années de Charles Perrault," Revue d'Histoire Littéraire de la France 13 (1906): 656-57.

21. Cited in A. Laprade, N. Bourdel, and J. Lafond, François d'Orbay (Paris: Vincent, Fréal et Compagnie, 1960), p. 43.

22. Ibid., p. 42, note 3 .

23. Histoire de l'Académie royale des inscriptions et belles-lettres (Amsterdam: n.p., 1719), 1:4-5. 
Academician without instruction, and rhymer of the lowest style, scarcely able to emulate his most clumsy colleagues, he knew no more than to be their protector, one of these low-grade Maecenases who promote mediocrity in order to appear superior to it ... and deprave literature by their wiles as much as they dishonor it by their writings. ${ }^{24}$

In sifting the truth from among all the accusations, the telling evidence must come not from partisan opinion but from Perrault's own work. The assessment of literary talent is highly subjective, but it is a fact that some of his poetry has been praised by later scholars and that his Tales have received accolades over the centuries as models of prose clarity, charm, and elegance. In terms of longevity and popularity, that particular work has had far greater success than anything ever written by all of his critics combined.

There are also some traits of character that may be discerned from the record of his accomplishments. He possessed a strong sense of family loyalty and protectiveness, particularly regarding his brother Claude, whom he eulogized in the Illustrious Men. Loyalty toward his colleagues was also evident in the Quarrel of the Ancients and Moderns, in which he continued to defend the abilities of writers such as Quinault and Chapelain despite ridicule. Tenacity was a trait that sustained him in nearly twenty years of devoted service to Colbert and saw him through the long years of the Quarrel and the production of the massive Parallel of the Ancients and Moderns. And regardless of whether or not his peers' resentments were justified, it took a special kind of courage for Perrault to continue so actively in the French Academy after Colbert's death, when he became an object of open attack. Perrault also had a dry humor that is one of the most appealing aspects of the Tales and gives several of his poems a gentle wit that contrasted sharply with Boileau's satirical destructiveness.

Some of Perrault's personal beliefs are reflected in his work as well. He demonstrated a consistent interest in Christian subjects, from his several poems about Biblical figures or saints to the unfinished manuscript of Christian Thoughts. Then, in his Apology of Women, he manifested sincere offense at the hostile caricatures of Boileau's satire and offered a strongly positive and respectful depiction of female virtues. Many of his writings display an affectionate attitude towards children and family life and a belief in the importance of moral and spiritual education.

Most importantly, there is evidence of Perrault's true character in the ability he possessed to communicate a sense of his own personality, through a variety of writings that lead us ultimately to the Memoirs. Even in its incomplete and unrevised form, this precious document acquaints us with the man in an intimate way; although the reader may not choose to believe that everything he says is strictly factual, the manner in which he expresses his thoughts offers a different and more profound truth. The Memoirs were written to provide a record of what Perrault
himself considered to be the most important events of his turbulent career, and of

24. Oeuvres complètes de Boileau-Despréaux (Paris: Peytieux, 1825), “Discours preliminaire," p. xix. 
how he wanted his reader to interpret those events. But what Perrault also revealed through the act of writing is the force of his character, driven by a persuasive intelligence and an underlying sincerity that is impossible to falsify. Perrault wants us to believe him, and ultimately we do, not because he is accomplished in his manipulation of our sympathies, but because his reactions and observations ring true in terms of our own experience of human nature. There is also believability in the scenes he evokes, in which a conversational exchange can convey a message about social conventions and hierarchies of power, and a polite phrase can suggest an attitude of contempt. The people he describes are alive in these pages, and none more so than Perrault himself as we come to know him.

A final comment is perhaps deserved regarding why Perrault's life has been so neglected by history. For an author whose work has achieved worldwide recognition, as in the case of the Tales, it is difficult to believe that only a handful of biographical studies of him exist, or even that his Memoirs should not have been translated into English prior to this edition.

First, biographical scholarship has been impeded by the fact that the Memoirs themselves provide virtually all of the known information about Perrault's personal life. No other contemporary memoirs or documents provide extensive corroboration, or convincing refutation, of many of the facts as he presents them himself. Some memoranda regarding his administrative duties do exist, but aside from his own surviving printed works and manuscripts, we have only the registers of the French Academy to prove the extent of Perrault's contribution to intellectual life. It is an unfortunate irony that because of Perrault's own care to preserve vital personal documents for posterity, he donated them to the State, and after being stored among the Buildings Accounts at Versailles, they were ultimately placed in the King's Library in the Louvre, where they were destroyed by fire in the Commune revolt of I87I.

Second, the very duality of Perrault's life as a public servant and man of letters, abetted by the disciplinary divisions of scholarship, has meant that his perceived identity has always been somewhat fractured. Just as many of his contemporaries were unable to judge him as being anything other than Colbert's inside man, despite his legitimate credentials as a writer, scholars over time have interpreted his life from the standpoint of their own restricted interests. Beginning in the nineteenth century, folklorists and psychologists have studied Perrault's Tales, but their object has been to reconstruct the values and attitudes of a culture, with little concern for the actual authorship of a tale. Historians know of Perrault as a functionary associated with Colbert, whose importance vanishes with his dismissal as Superintendent of Buildings, although his most important writings would come in the years that followed that event. Literary criticism, in its turn, has largely ignored Perrault, at first because throughout the eighteenth and nineteenth centuries he was not considered a true "author," but rather a scribe for the Tales who was otherwise a mere literary hack. 
More recent criticism has acknowledged the legitimacy of Perrault's written achievements, but with the exception of Marxist or ideological theorists, most modern critics have shunned biography as a guideline for the interpretation of an author's work. A text is often seen to represent an independent entity that possesses its own structure and coherence, having very little relevance to the circumstances of an author's life.

One of the most important contributions of the Memoirs, therefore, is the fact that not only does it provide a substantive record of events, but it presents us with Perrault as he saw himself, and not as later critics would see him. Perrault was an individual for whom there was no inherent contradiction between a dedication to both art and public service, and despite the complexities of his career, the portrait he gives of himself is consistent. As we read the Memoirs, it seems natural for a writer to supervise the construction of a monument that would proclaim the glory of the monarch, just as it seems appropriate for a poem to celebrate a military victory or enumerate the virtues of a patron without whose support no artistic creation would be possible.

The Memoirs also introduce us to the personalities who dominated events during some of the most important moments in the artistic history of seventeenth-century France, reminding us that it was human enmity and connivance, not aesthetic principle, that often determined the outcome. With his astute observations, and by the example of his own life, Perrault gives us insight into the personal drama that is often lost in historical accounts, but is essential to our understanding of the seventeenth-century artistic spirit. Charles Perrault was very much a part of what his poem christened as "The Age of Louis the Great," and his Memoirs offer us a glimpse into that past through the eyes of one of its most remarkable men.

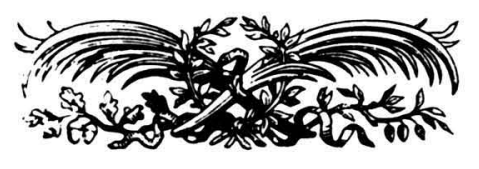




\section{A NOTE ON THE TEXT}

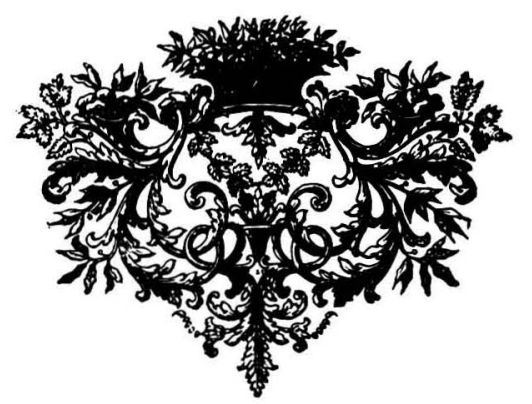

Perrault's Memoirs were never published in his lifetime. Their first documented appearance in print was in the eighteenth century, in a version that was heavily altered by an architect named Patte (Avignon, 1759). In the following century, the scholar Paul Lacroix, under the pseudonym P. Jacob, published another edition (Paris: C. Gosselin, 1842), which was accompanied by an interesting Dissertation on Fairy Tales by Walckenaer. That edition also, however, made numerous changes in the text. It was not until 1909 that Paul Bonnefon (Paris: Librairie Renouard) edited a version that was faithful to the original manuscript.

Bonnefon was the first serious researcher of Perrault's life, and to him an enormous debt is owed. In his publication of the Memoirs, and in a series of articles published in the Revue de l'histoire littéraire de la France at the turn of the century (1900-1906) and in the Gazette des Beaux-Arts (1908), he uncovered numerous documentary records of Perrault's career. More importantly, he brought Perrault to the attention of the scholarly public, beginning the "rehabilitation" of a much-neglected historical and literary figure.

A general biography of Charles and Claude Perrault was published by André Hallays in 1926 (Les Perrault, Paris: Librairie Académique Perrin). Hallays' interest was in the Perraults as a family unit of remarkable accomplishment, and he documented not only the individual achievements of the five brothers, but also the relationships among them. Hallays provides insight into the strong sense of family loyalty that affected Perrault's career and is so clearly reflected in the Memoirs' frequent use of the phrase "my brother."

Other important works on Perrault include the scholarly editions of Perrault's Tales by Rouger (Garnier, 1964), Collinet (Gallimard, 198I), and Zuber (Imprimerie Nationale, 1987), and a biography of Perrault by Barchilon and Flinders (Twayne, I98I), which offers an analysis of Perrault's literary works in addition to the Tales.

The original manuscript of the Memoirs is presently in the collections of the French National Library, the Bibliothèque Nationale, after having been previously owned by 
the Library of the Cathedral of Notre Dame. It is evident from the text that this was an actual working draft, with occasional corrections and insertions, and not yet in its intended final form. Paragraph indentations are few, and additional breaks have been made, where logical, in the present edition. There are also marginal notes in Perrault's hand, identifying the general subjects under discussion, which have been reproduced here as subheads. The division of the text into five parts is the choice of the present editor.

Several of Perrault's changes in the draft indicate the writer's technique, as in an occasional word used once too often, crossed out, and then replaced by a different alternative. There are also statements that Perrault the politician thought better of and lined through, clearly intending that they be eliminated from a future version; on p. $78 \mathrm{~b}$, for example, the name of the King's mistress Mademoiselle de la Vallière is spelled out, then Vallière is crossed out and replaced by simply $V$. Other changes reflect Perrault's modesty; first describing himself as "the youngest and the best" student in his class, he changes it to "the youngest and one of the best" (p. 3b). Occasionally, we even see indication of a memory lapse, as when he writes a sum of "twelve hundred livres," crosses out "livres" and writes "écus," and then crosses out "écus" as well (p. 28b).

In general, however, the text of the manuscript flows smoothly, with very few passages rewritten extensively. One such rewrite does occur when he is reconstructing a dialogue between the King and an important Academician, and another occurs when he is describing the crucial event with which the manuscript ends: the moment when his colleagues in the Academy attack his praise of modern writers. Nevertheless, these passages are rare, and the fluidity of Perrault's expression assures us that his memory was clear, and that he was expressing his true feelings without equivocation. We can only speculate as to how lengthy and precise the Memoirs might have become, had Perrault lived to see their completion; but the manuscript we possess is in a sense a living entity, and a fitting testament to a man whose personality still remains compelling after the passage of three centuries.

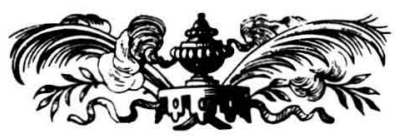




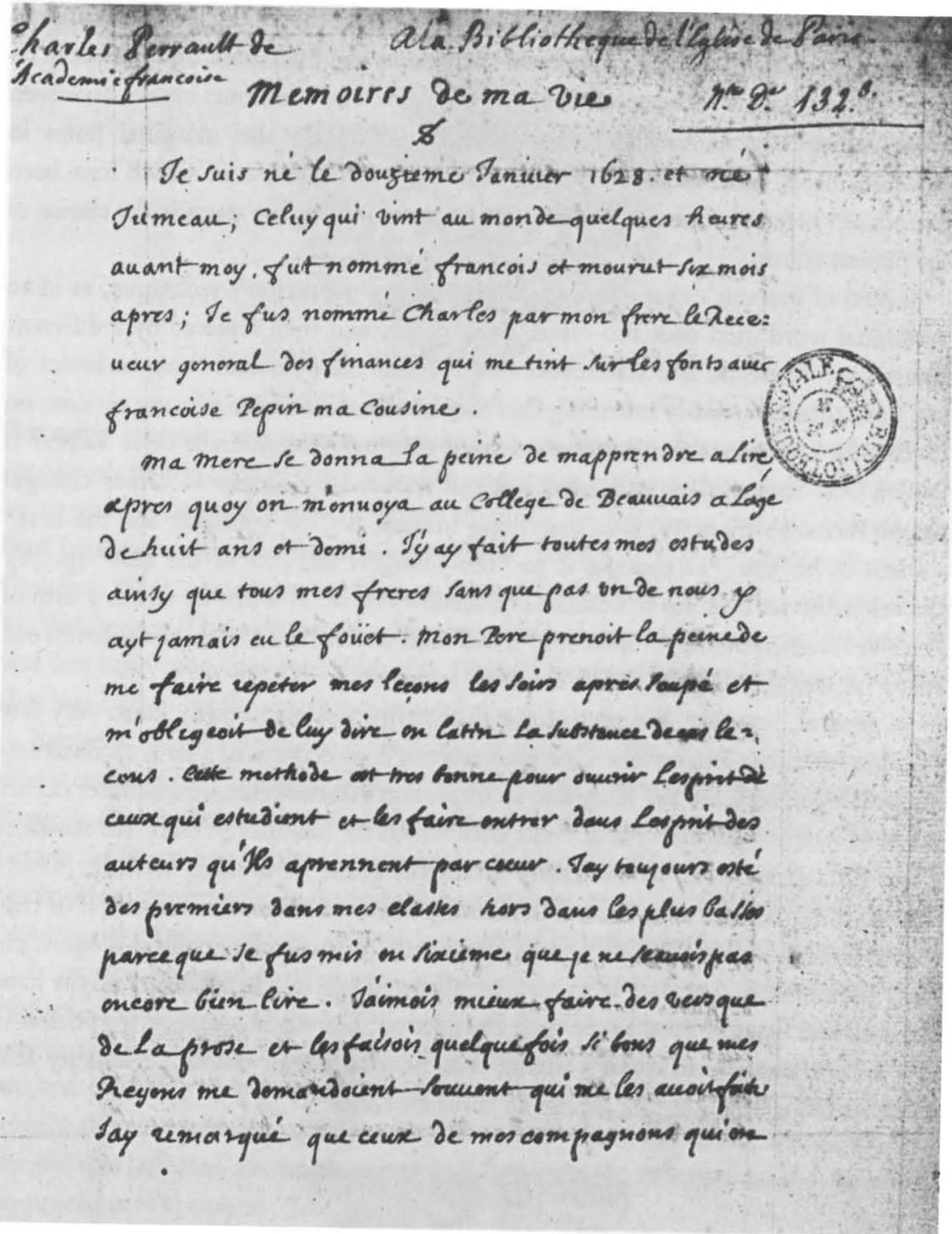

Title Page, Manuscript of Mémoires de ma vie. Courtesy Bibliothèque Nationale. 


\section{Part 1 \\ THE EARLY YEARS}

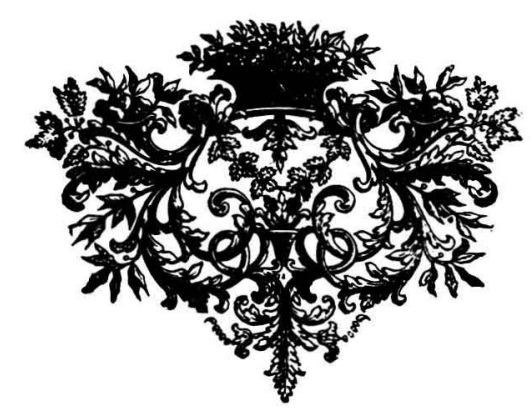

I was born on the twelfth of January 1628, and born a twin. He who arrived in the world a few hours ahead of me was named François, and died six months later. I was named Charles by my brother the tax collector, who held me at the baptismal font with my cousin Françoise Pepin. ${ }^{\mathbf{r}}$

My mother took it upon herself to teach me to read, after which I was sent to the College of Beauvais ${ }^{2}$ at the age of eight and a half. I took all my lessons there, as did all my brothers, without one of us ever being whipped. My father took the trouble to make me repeat my lessons every evening after supper, and made me tell him in Latin the substance of these lessons. This method is very good for broadening the minds of those who study and making them enter into the thinking of the authors whom they learn by heart.

I was always among the top students in my classes, except at the very beginning, because I was placed into a sixth-year class when I could not yet read well. I preferred to write verses rather than prose, and sometimes wrote them so well that my teachers often asked who had written them for me. I have noticed that those of my companions who wrote verses well have continued to write them, it being true that this talent is innate and declares itself even in childhood.

I was particularly successful in philosophy: it was often enough for me to pay attention to what the teacher recited, in order to know it by heart, and to have no need to read and study it afterwards. I took so much pleasure in class debates that I enjoyed the days we went to school as much as the holidays. The aptitude that I had for debate led me to speak to my teacher with an extraordinary liberty, which none of the other students dared take. Since I was the youngest and one of the best students in my class, he wanted very much for me to defend a thesis at the end of the second year; I. Charles Perrault was baptized on I3 January 1628 at the Church of St. Étienne-du-Mont in Paris,
seventh child of Pierre Perrault and Pâquette Leclerc, and godson of his elder brother Pierre (I6II-I680). 2. The Collège de Beauvais, a secondary school, was founded in I370 by Cardinal Jean de Domans, nian $\mathrm{C}$ of Beauvais, and was located in the Rue Jean-de-Beauvais near the Sorbonne, where the Rumanian Church now stands. Nicolas Boileau also attended this school, more than ten years after Perrault. 
but my parents decided against it because of the expense which this ceremony entails, the most useless expense it is possible to make. The instructor was so vexed at this that he made me be silent when I wanted to debate against those who were going to defend theses. I was bold enough to tell him that my arguments were better than those of the Irish students whom he had invited, because mine were new and theirs were old and worn out. ${ }^{3}$ I added that I made no apologies for speaking thus, because I knew only what he himself had taught me. He ordered me a second time to be quiet, upon which I said to him, rising to my feet, that since he no longer had me recite my lessons (for in those days philosophy students repeated their lessons every day, like other students, and it is a great shame that this is no longer required), since no one argued with me any longer, and since I was forbidden to debate with the others, I no longer had a reason to come to class. Upon saying this, I bowed to him and to all the other students, and left the class.

One of my friends, named Beaurain, who was very fond of me, and who had in a way taken my part because the whole class had turned against him without his knowing why, left also and followed me. We went from there to the Luxembourg Gardens, where, having reflected upon what we had just done, we resolved never to return to class. It could offer us no further benefit, since all the time was devoted to things other than allowing practice time to those who should have been speaking. We determined to study together on our own.

This mad impulse had a happy result; for if we had completed our studies in the ordinary way, we would obviously have applied ourselves, each in our own way, to doing nothing of importance. We carried out our resolution, and for the next three or four years, Monsieur Beaurain came to my home twice a day, almost every day, from eight to eleven in the morning and from three to five in the afternoon. If I know anything at all, I owe it particularly to those three or four years of study. We read nearly all of the Bible, nearly all of Tertullian, 4 and the History of France by La Serre and Davila; 5 we translated Tertullian's treatise On Female Dress; we read Virgil, Horace, Cornelius, Tacitus, and most of the other classical authors, writing down passages from them that I still possess.

The manner in which we made most of these extracts was very useful. One of us would read a chapter or a certain number of lines, and after reading it, he would dictate a summary of it in French, which we both wrote down, keeping the most beautiful passages in their original language. After one of us had read and dictated in

3. At the time of writing the Memoirs, Perrault had been embroiled for at least five years in the Quarrel of the Ancients and Moderns, and this incident refutes his critics' charge that his modernist views had been hastily conceived and did not reflect his true opinions (see conclusion, Part 4).

4. Tertullian (c. I5S-c. 222) was considered the first Christian Latin author and had an important influence upon the development of Church Latin.

5. Enrico Davila wrote History of the Civil Wars in France, published in 1630 and translated into French in 1644; Jean de la Serre was the author of Panegyrics of Famous Men of Our Century and of History or Portraits of the Empresses, Queens, and Illustrious Princesses of the Revered House of Anne of Austria, published in the 16405 . 
this way, the other one did the same; this accustomed us to translating and excerpting at the same time. In the summer, when five o'clock sounded, we went to walk in the Luxembourg Gardens. Since Monsieur Beaurain was more studious than I, he continued to read after he went home, and during our walks he repeated to me what he had read.

\section{BURLESQUE TRANSLATION OF THE SIXTH BOOK OF THE $A E N E A D$}

At that time the burlesque style came into fashion. Monsieur Beaurain, who knew that I wrote verse but could never do it himself, wanted us to translate the sixth book of the Aenead into burlesque verse. One day when we were working on it, and were still only at the beginning, we started to laugh so loudly at the silly things we were putting into our work that my older brother, the one who later became a doctor of the Sorbonne, ${ }^{6}$ and whose room was next to mine, came in to see what we were laughing at. We told him, and since he was still only a student, he sat down to work with us and helped us a great deal. My brother the physician, who learned how we were amusing ourselves, decided to join in; he accomplished more by himself, in his spare time, than the rest of us had done all together. In this way, the translation was finally completed, and after I copied it out as neatly as I could, he made two very beautiful illustrations with China ink. This manuscript is among the books on the shelf where we keep those by family members.

\section{THE WALLS OF TROY}

This work inspired us to do The Walls of Troy, or On the Origin of the Burlesque, of which the first book was a collaborative effort and has been published, and the second book is still in manuscript and was written entirely by my brother the physician.? We carried our sense of the ridiculous a bit too far in this book, but there are some excellent pieces. And its overall subject is very good, because it allows for such ingenuities as saying that Apollo invented pastoral poetry because he had once been a shepherd in the kingdom of Admetus. And, that Apollo conceived of the burlesque because in building the walls of Troy with Neptune, it was in the workshops of masons and laborers that he learned the humble expressions which are part of burlesque style.

6. Nicolas Perrault (1624-I662) was only four years older than Charles. The five surviving Perrault generers were, in order of age: Jean (d. 1669), a lawyer; Pierre (16II-1680), who became a receiver Nicolas. finances for the city of Paris; Claude (1613-I688), a doctor of medicine and amateur architect; by Charles who became a theologian at the Sorbonne; and Charles. According to a handwritten epitaph 7. Les Murs. Nat. ff. ms. 24713), there was also a sister, Marie, who died at the age of thirteen.

second Murs de Troye, ou l'origine du Burlesque was published in I653 (Paris: L. Chamhoudry). The

Bonnefon in was discovered in manuscript at the Bibliothèque de l'Arsenal and was published by Paul Bonnefon in the Revue d'histoire littéraire de la France 7 (1900): 449-72. 
All that our imaginings lacked was antiquity, in order to win the admiration of scholars. There are two verses in the sixth book of the Aenead which have been much admired: they are in the place where Virgil says that the heroes retained the same habits in the Elysian fields that they had had in life. The translation says that one might see Tydaeus the coachman, "Who, holding the ghostly shade of a broom, / Swept out the shade of a coach." Cyrano ${ }^{9}$ was so delighted to see that the chariots were only ghosts, just the same as the servants who had charge of them, that he insisted upon making our acquaintance. The idea for this came from Nicolas.

\section{PORTRAIT OF MY BROTHER THE THEOLOGIAN}

Your uncle the tax collector [Pierre] has made such a good description of your uncle the theologian, of whom I am going to speak now, that I will limit myself to relating a few incidents in his life which your uncle Pierre forgot. ${ }^{\text {ro }}$ When Nicolas defended his thesis in theology, he was already held in such high esteem at the Sorbonne that the professor lecturing to the adjunct school announced to his students that he would not give a lesson that day, because it would be more useful for them to go and hear the student who was presenting his defense than to learn their lesson; he invited them all to attend, and he said that he was going there himself."

Besides the fact that my brother had studied a great deal, God had given him the grace to enter so well and so far into the spirit of religion, that I would dare to say that few people have ever known more than he about the true workings of the Christian religion. Monsieur Beaurain, of whom I have already spoken, went to him from time to time with questions or objections, and my brother replied to these so aptly that Beaurain always came back as satisfied as he could be. I remember that he said to me one day, "When I go to Monsieur de Sainte-Beuve (who was an excellent man), after two or three of my arguments he cuts me off with these two words: $O$ altitudo!12 and that's the end of that. But Monsieur the doctor," he continued, speaking of my brother, "never gets to that point. He leads me from one truth to the next, showing me such admirable connections between them that I haven't a word to say in response; he reveals to me such a marvelous order among all the Christian mysteries that I always leave him with renewed conviction. No one speaks as he does about matters of faith."

8. Tydeus was actually a hero who had fought against Thebes, and in Virgil's original text, "Aeneas stood at a distance, marvelling much at their armour, their phantom chariots . . . The pleasure they took when alive, in their armour and chariots, aye, and the care in putting their sleek-coated horses to pasture, remained beside them, unchanged, in the world under the earth" (trans. M. Oakley [London: Dent, 1964], p. I3I).

9. Cyrano de Bergerac (1619-1655), prominent author and materialist philosopher.

10. Pierre's biography of Nicolas was presumably among the family papers lost or destroyed.

II. Nicolas Perrault defended his thesis at the Sorbonne on 27 January I648; his subject was "Quis ostendet nobis bona?" (Who reveals virtues to us?). A manuscript copy of the thesis survives in Paris at the Bibliothèque Nationale (f.f. 24713).

12. In Latin, "What profundity!" 
When he delivered a speech at the Sorbonne, in defense of Monsieur Arnauld, ${ }^{13}$ the chancellor asked who he was, as my brother Pierre has described. Monsieur the Chancellor then said that he hoped there were many young scholars with his power, adding these words: "He spoke like a lawyer, and not like a scholar." This was a great compliment, since the chancellor meant that instead of beating the bushes in search of impressive citations, like most scholars, he had gone straight to the heart of the matter. This pleased the chancellor so much that he intervened three or four times with the hourglass keeper, whose duty was to restrict each scholar to a quarter of an hour, and prevented him from imposing silence. Thus the harangue lasted almost one and a quarter hours, and when he ended his speech they were still listening for more.

It might be supposed from this that my brother was very close to Monsieur Arnauld. However, when I asked him one day what Monsieur Arnauld had replied to a certain objection that someone had made to him, he replied that he knew nothing about it.

"How can it be," I said to him, "that you have not asked him?"

"I have never spoken to Monsieur Arnauld," he answered, and I was never more surprised at anything than I was at this reply. "I have not wished to see him," he told me, "because I want to be certain, as much as possible, that my beliefs about grace are not derived from flesh and blood, and that it is not friendship which leads me to support one idea over another. I therefore have reason to believe that it is God alone who inspires me." Not only did he fear that flesh and blood might have some bearing upon his feelings about matters of faith, but he feared that others with whom he conversed might do the same thing toward him, and agree with his opinions out of friendship.

He proved the truth of this in an incident which I will relate. He was a good friend of Monsieur Varet, who later became the Vicar General of the Bishop of Sens, an excellent man. ${ }^{14}$ Monsieur Varet was still quite young, and he had been raised by his mother, a very pious woman, in the great fear of being poisoned by the false doctrines which were circulating within the Church at the time. He was very distressed because of my brother, whom he was obliged to see often because of their friendship, the fact of their being neighbors, and even their family relationship, since our second cousin Monsieur Pepin had married his sister, Mademoiselle Varet. He knew my brother to be a very good man, a priest and a doctor of the Sorbonne, but my brother was suspected of Jansenism.

\footnotetext{
I3. The theologian Antoine Arnauld (I6I2-1694) was censured by the Sorbonne in 1656 for having Alended certain propositions of the Jansenists that had been condemned by Popes Innocent X and Alexander VII. Arnauld argued logically that none of the five propositions was actually stated by Jansenius; nevertheless, he and seventy-two of his supporters, including Nicolas Perrault, were excluded from teaching at the Sorbonne.

14. Alexandre-Louis Varet $(1632-1676)$, an author of treatises on the education of children and the public repentance of sins, died at the Jansenist abbey Port-Royal-des-Champs.
} 
My brother, observing his dilemma, said to him: "Are you not convinced that the doctrine of Saint Augustine on grace is the doctrine of the Church?"

"Yes," said Monsieur Varet, "and I even know that the canons of the Council of Trent on the subject of grace were composed from Saint Augustine's own words." Is

My brother then told him, "Then you would have no repugnance about reading what this Father of the Church wrote about grace?"

"Of course not," replied Monsieur Varet.

"Then read it," my brother said, "after which we will speak as much as you like about the matter; until then we will please not say a word. There are a thousand other theological questions which we can examine in the meantime."

After a few days, Monsieur Varet wanted to talk about grace; my brother asked him if he had read all of Saint Augustine yet.

"No," said Monsieur Varet.

"Then let's talk about something else," replied my brother. When Monsieur Varet had read all of Saint Augustine on grace, my brother allowed him to speak; but he found that Monsieur Varet carried things a bit too far, and it took a long time to make him see the judicious limits which must be observed within this subject.

When he was excluded from the Sorbonne, with the seventy other theologians who shared his opinions, ${ }^{16}$ not only did he stop going there, but he refused to attend the priests' meetings at Saint-Étienne-du-Mont, his parish. The parish priest saw that without my brother, the meetings seemed to have no soul, for it was he who proposed and resolved a great number of the questions and matters of conscience that were debated there. The priest came two or three times to beg him to attend the meetings.

"How can you, Monsieur, make such a request?" said my brother. "I am one of those whom you accuse in your pulpit of adhering to poisoned doctrine, and you want me to attend your discussions!"

The priest pleaded in vain, for my brother felt it his duty to avoid the scandal which might have been caused by his presence.

A thousand people told my brother every day that he should sign the Formulary, because a man like him should not be kept by so small a thing from being useful to the Church, either by preaching, giving confession, or attending ecclesiastical discussions.

He responded to all this with an answer which is assuredly very Christian and very

15. The Council of Trent, held in three sessions from I545 to 1563 , was convened in order to find a political solution to the Protestant movement, initiating reforms within the Church and reaffirming Catholic dogma. The teachings of Saint Augustine were a source of controversy here because of Jansenius's condemned treatise, Augustinus (1640), which his followers claimed was not heretical, but rather was faithful to Augustinian doctrine.

I6. In 166I, the Catholic clergy was required to sign the Formulary, a document repudiating Jansenist views. Among those who refused was Angelique Arnaud, Antoine's sister and the abbess of PortRoyal. 
sensible: "God has no need of me for all the duties you mention, and I should think only of the one with which he has charged me. He made me by his grace a doctor of the Sorbonne, and I see myself in that capacity as a sentinel, put on watch against violations of the truth. That is my only task, and if I perform it well, I will have accomplished a great deal. God will take care of all the rest." I later used this thought in my eulogy of Monsieur Arnauld, where it is particularly appropriate. ${ }^{17}$

Nicolas was a very good man who undoubtedly died too young. He never looked for reward, and his whole ambition was to be a professor of theology at the Sorbonne, which he would have done admirably well.

\section{ORIGIN OF THE “PROVINCIAL LETTERS”}

During the time when meetings were being held at the Sorbonne to condemn Monsieur Arnauld, my brothers and I, with Monsieur Pepin and a few other friends, wanted to know the truth of what was going on. We asked our brother Nicolas to instruct us on the subject, and we all met at the house of my late father.

My brother explained to us that all the questions about divine grace that were causing so much commotion turned on the issue of immediate power versus remote power, by which grace brings about good works. Some people said that in fact, when Saint Peter sinned, he did not possess the grace which gives the immediate power to do good, but that he possessed the grace which gives remote power; that kind of grace never actually produces a good deed, but merely provides the power to perform it. According to this view, Monsieur Arnauld was wrong to say that Saint Peter was an example of a just man who nonetheless was without grace, and without grace nothing good can be accomplished.

The others maintained that since remote power never produces a good deed, and since Saint Peter lacked the kind of grace which does, then Monsieur Arnauld was not wrong when he said that Saint Peter did not have the grace without which nothing can be accomplished. It stands to reason that a power which never produces an effect is not a true power.

At this point, we realized that the question hardly deserved all the commotion it was causing. My brother the receiver [Pierre] described this meeting to Monsieur Vitart, the steward of the Duke de Luynes, who lived at Port-Royal. Pierre told him that the gentlemen of Port-Royal should inform the public of what was going on in the Sorbonne, in order to dispel the belief that Monsieur Arnauld was being accused of grievous crimes.

A week later, Monsieur Vitart came to Pierre's house in the Rue Saint-François of

\footnotetext{
I7. In the first volume of Illustrious Men Who Have Lived in Our Century (1697), Perrault wrote the anything of Arnauld: "he viewed himself in this post, in a way, as a sentinel placed there to prevent anything from happening that was opposed to the truth" (p. Is).
} 
the Marais, where I also lived, and brought him the first Provincial Letter by Monsieur Pascal.

"Here," he said, presenting the letter, "is the fruit of what you told me a week ago." This letter, which discusses that very subject of the immediate and remote power of divine grace, led to a second letter, and that one to another, up until the eighteenth, which is the last of the Provincial Letters. This was their true origin and inspiration. ${ }^{18}$

Let us retrieve the thread of our subject. In the month of July I65I, I went to take a university degree at Orléans, along with Monsieur Varet, of whom I have already spoken and who later became the Vicar General of the Archbishop of Sens, and with Monsieur Menjot, who is still living. ${ }^{19}$ In those days they were not as strict as they are today in granting degrees, not even for degrees of civil and canonical law.

The very same evening of our arrival, we took it into our heads to present ourselves. We pounded on the door of the college at ten o'clock at night, and a servant spoke to us from a window; when he learned what we wanted, he asked us if our money was ready. When we replied that we had it with us, he admitted us and went to wake up the scholars, who came in a group of three to interrogate us, wearing their nightcaps underneath their mortarboards. Looking at these three scholars in the feeble glow of a candle, whose light was lost in the thick darkness of the vaulted ceilings of the place where we were, I imagined I saw Minos, Aeacus, and Rhadamantus coming to interrogate the shades of the dead. 20

One of us, who had been asked a question that I do not recall, boldly answered, "Matrimonium est legitima maris et feminae conjunctio, individuam vitae consuetudinem continens,"2I and on that subject he said an infinite number of fine things which he had learned by heart. Then they asked him another question, to which his reply was worthless. The two of us remaining were then examined, and did little better than the first. However, these three scholars told us that it was over two years since they had examined such clever students, and who knew as much as we did. I think that the sound of our money, which someone was counting behind us during our examination, played some part in making them believe our answers to be better than they actually were. The next day, after seeing the Church of Sainte-Croix, the bronze statue of the Maid of Orléans on the bridge, and a great number of lame men and women throughout the city, we set out on the road back to Paris. On the twentyseventh of the same month, all three of us were officially received as lawyers.

I8. On 14 January 1656 , the "five propositions" of Jansenius were censured, and Pascal's first Lettre provinciale appeared on 23 January. Three letters had appeared before Arnauld was excluded from the Sorbonne on Is February, and additional letters were published every few weeks until March 1657.

19. "Monsieur Menjot" was probably the son of Antoine Menjot (1615-1695), a physician. He would have been approximately eighteen years old at the time of this incident, while Varet was nineteen and Perrault was twenty-three.

20. Minos, the son of Zeus and Europa, was a king of Crete renowned for his wisdom. With his brother, Rhadamanthus, he served as one of the three judges of the underworld.

2I. In Latin, "Matrimony is the legitimate union of husband and wife, encompassing the intimate relations inseparable from life." 
I studied The Institutes ${ }^{22}$ and learned them very thoroughly, without a teacher but with the help of Borkolten's commentaries. The Institutes is an excellent book and the only one which I think is worth saving out of Roman law. Aside from this book, which is very good for supporting common sense and common law (which could usefully be reduced to a single standard throughout France, if possible, the same being true for weights and measures), I think it would be good to burn all the other books of jurisprudence, digests, and codes, with all their commentaries, and especially all the records of arrests. There would be no better way in the world to reduce the number of lawsuits.

I pleaded two cases with a fair degree of success, not because I won them both, since winning or losing a case is rarely up to the lawyer, but because those who heard me professed to be very satisfied, especially the judges. After I bowed to them at the end of the session, they gave me unusually high praise, especially Monsieur Daubray, the civil lieutenant and the father of the unfortunate Madame de Brinvilliers. ${ }^{23} \mathrm{He}$ even asked me to become affiliated with the Châtelet ${ }^{24}$ and said that I would receive from him every mark of favor for which a lawyer could hope. Perhaps I might have done better to follow his advice, but my brothers' experience gave me such a distaste for the profession that I took an active dislike to it. There was a very good reason for this, which was that my oldest brother [Jean], who was a very skillful lawyer, who knew his trade perfectly well and had more wit and eloquence than any of his colleagues, had almost no success in his career. He shone with talent, but he did not know how to shine in his profession. I thought that this might happen to me, and what is worse, it seems that I was not far wrong.

Be that as it may, my brother Pierre having purchased the post of Receiver General of Finances for the city of Paris, and having invited me to be his clerk and to live with him, I accepted the invitation. I foresaw more enjoyment and pleasure in this than in trailing a robe through the Palace of Justice. I was with him for ten years, because I started in the beginning of the year I654 and I left to work for Monsieur Colbert in $166_{4}$.

Since the duty of general receiving was not very demanding, consisting merely of

22. Gaius, a Roman scholar of jurisprudence, wrote the Institutiones in the second century A.D., which formed the basis for the Institutes of the Byzantine emperor Justinian I (482-565). The Justinian Code was established in 529.

23. As mentioned in a letter of Madame de Sévigné (I May 1676), Marie-Madeleine, the Marquise of Brinvilliers (1630?-1676), was the lover of Gaudin de Sainte-Croix, a young officer and a friend of her husband. By order of her father, Dreux d'Aubray, Sainte-Croix was imprisoned in the Bastille, where tio shared a cell with Exili, an Italian who was a specialist in poisons. The Marquise obtained a separation of property from her husband; however, between 1666 and 1670 , her father, two brothers, and a sister all died of poisoning. There was an attempt against her husband, but he was given an antidote by Sainte-Croix, who himself succumbed to a sudden death in 1672 . The Marquise fled to England, then to Liège in Holland, where she was arrested; after her full confession, she was decapitated and burned on I6 July 1676.

24. The Châtelet was a fortress constructed on the right bank of the Seine River, which housed the the criminal courts for the city of Paris until its demolition in 1802 . A smaller fortress of the same name, on the opposite bank, served as a prison until its own destruction in $\mathbf{1 7 8 2}$. 


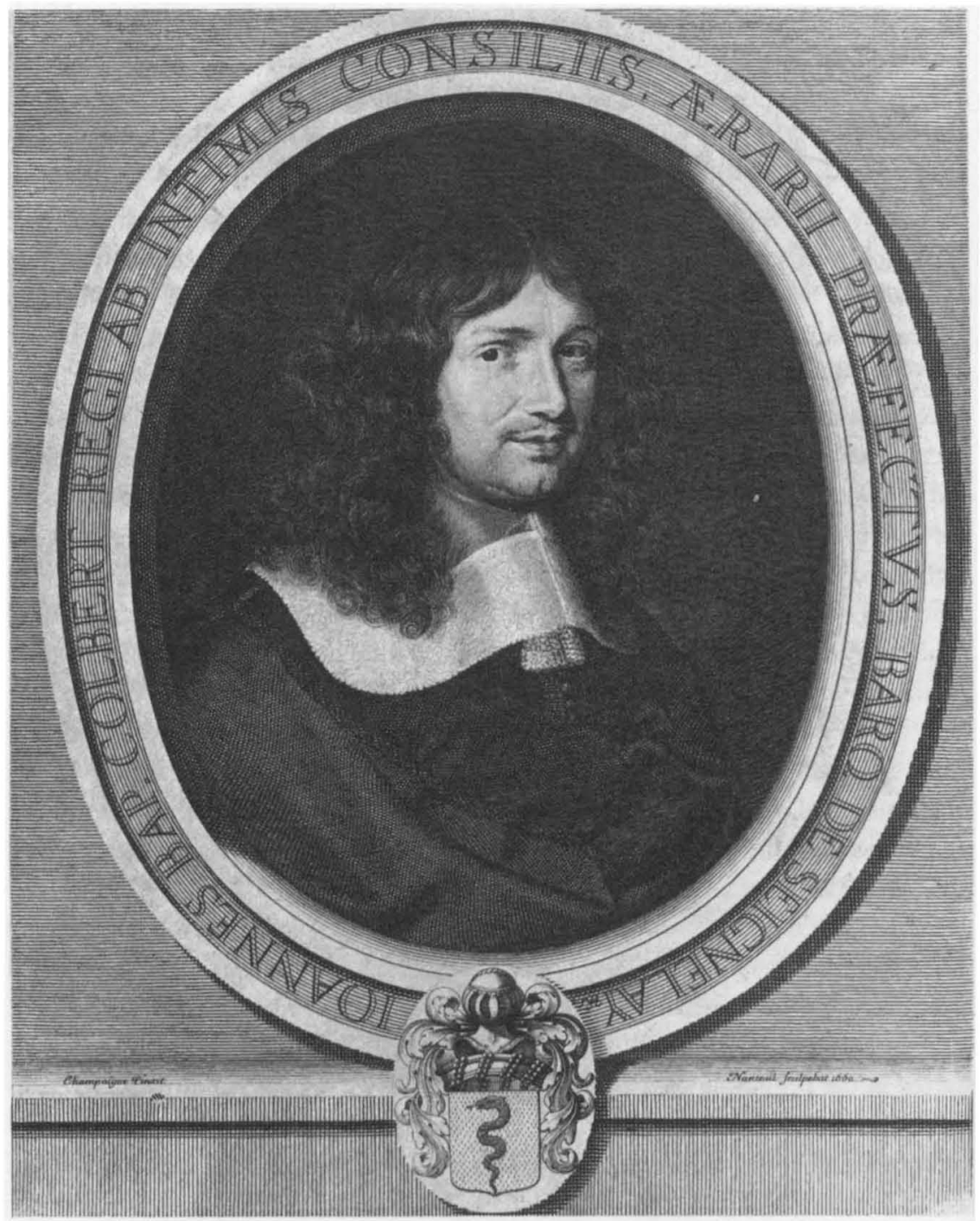

Jean-Baptiste Colbert. Engraving by Nanteuil (1660), after painting by De Champaigne. Courtesy The Metropolitan Museum of Art, Gift of Carl J. Weinhardt, Jr., I958 (58.558.I).

going to pick up the money and delivering it either to the bank (which was not yet called the Royal Treasury) or to certain individuals who had a lien on the revenues, I went back to studying. This was prompted by a very beautiful library, which my brother purchased from the estate of the Abbé de Cérisi, who was a member of the French Academy and the author of the Metamorphosis of Philis' Eyes into Stars. ${ }^{25}$ I took

25. Germain Habert, Abbé de Saint-Vigor de Cérisy (1614-1654), was one of the Academy's founding members. 
great pleasure in finding myself surrounded by such good books.

I also began to write poetry, and the Portrait of Iris was virtually the first work I ever composed. ${ }^{26}$ I have never done anything better in that genre, so true is it that when one has a natural talent, one does as well at the beginning as later on, and the only virtual difference is in the greater facility for writing which one acquires with time. One can eventually write in a week what would earlier have required two months or more. I wrote the Portrait of Iris at Viry, from an idle notion, and I never believed that it was nearly as good as people thought it was when it appeared.

Monsieur Quinault ${ }^{27}$ came to see us at Viry; I read it to him, and since he found it much to his taste, I gave him a copy. When he returned to Paris, he showed it to a young lady with whom he was in love, and who thought that he had composed it for her. He found it to his advantage to let her remain in error, and he felt no duty to enlighten her, and so the portrait made the rounds all through Paris under his name. ${ }^{28}$

Someone told me about this portrait, and I mentioned that I had made one with the same name of Iris. As soon as I spoke the first verse, they exclaimed that it was the same poem of which they had spoken. My word was believed, and Monsieur Quinault found himself in something of an embarrassing position. However, since he admitted openly that his romantic affairs had prospered because he was believed to be the author, and that he would have been proud to have written it himself, the episode did him no harm in the eyes of the world.

Later, I composed the Dialogue between Love and Friendship, which became very popular and was reprinted several times; ${ }^{29}$ it was translated into Italian by two different persons, and Monsieur Fouquet, the Minister of Finance, had it inscribed on vellum, with gold leaf and painted illustrations.

When my mother died in 1657 , shortly after the marriage of my brother the Receiver General of Finances (a marriage which brought her considerable joy), ${ }^{\circ}$ the house at Viry was left to my brother the Receiver in the division of the family estate. He had a small lodge built there, and as my time was completely free, since he had taken another assistant for general receiving, I devoted myself to the construction of this house, which has been thought well-arranged.

It is true that my brothers played a considerable part in the design of the building, but I could only get workers from Limoges, who had built nothing in their whole lives except cloister walls. I had them construct a rock grotto as well, which was the

26. Le Portrait d'Iris and Le Portrait de la voix d'Iris were published by Huet in 1659 , in a collection of

Divers portraits in honor of the Duchess of Montpensier, the niece of Louis XIII.

27. Philippe Quinault ( $1635-1688)$, poet, dramatist, and later librettist for the operas of Lully.

28. Paul Bonnefon discovered a copy of this work in the Bibliothèque de l'Arsenal (Conrart man-

uscripts no. 5-418, p. 709), with the author's name written as Quinault, then crossed out and corrected as Perrault.

29. Dialogue de l'Amour et de l'Amitié (Paris: Étienne Loyson, I660), reprinted in Recueil de divers ouvrages en prose et en vers (1675).

30. Pierre Perrault was married on 6 November 1656 to Catherine Lormier, a widow who was also the daughter of a judge. 
finest ornament of this country house. When they showed all this to their friends from Limoges as being their own work, they astonished them and acquired a great reputation for cleverness. ${ }^{3 r}$

I am relating my role in the construction of the Viry house, because the account of this which was given to Monsieur Colbert was the particular reason why he thought of me to be his clerk, supervising the King's buildings. This happened near the end of I663, in the manner which I will now describe.

31. This grotto was the subject of a poem by Pinchesne, a nephew of the poet Vincent Voiture, entitled “To Monsieur Perrault the Younger [Charles] on his Grotto at Viry" (Poésies meslées, I669, reprinted in Hallays, Les Perraults, p. 252). It was still extant in 1892 , when it was discussed at a meeting of regional fine-arts societies: "Monsieur de Montaiglon ended by describing a grotto still existing in very good condition in a beautiful country house in Viry-sur-Orge, near Juvisy; it was for Charles Perrault, the first commissioner of buildings and author of the Tales, that this grotto was made . ." (Réunion des Sociétés des Beaux-Arts des Départements [Paris: Plon, 1892], p. 32, meeting of 1o June 1892).

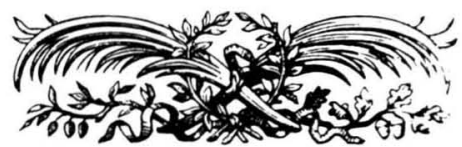




\section{Part 2 \\ COLBERT AND THE ACADEMIES}

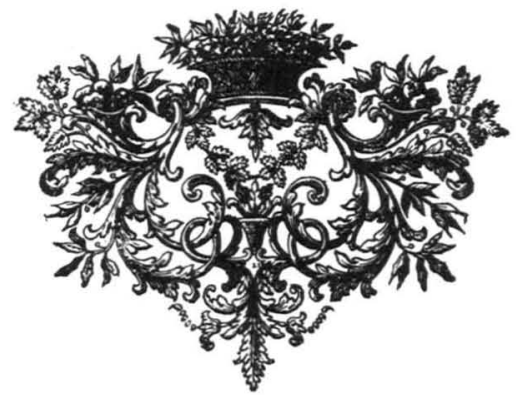

OPINIONS BEFITTING A MINISTER OF BUILDINGS

As early as the end of the year I662, when Monsieur Colbert had predicted or knew already that the King would make him Superintendent of Buildings, he began to prepare himself for carrying out this duty, which he considered much more important than it appeared to be in the hands of Monsieur de Ratabon. ${ }^{\mathrm{I}} \mathrm{He}$ imagined that he would have to work not only on finishing the Louvre, a project begun so many times and always left incomplete, but also on raising many monuments to the glory of the King, such as triumphal arches, obelisks, pyramids, and mausoleums. Nothing was too grand or magnificent for him to propose.

He thought also that it would be necessary to strike a large number of medals, to consecrate for posterity the memory of the great deeds which the King had already

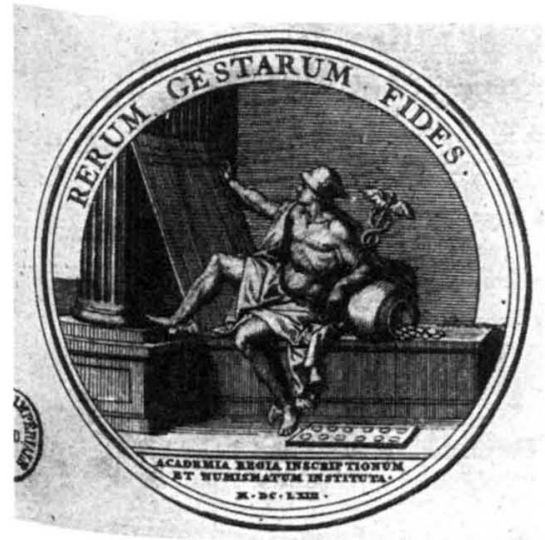

Medal commemorating the foundation of the Academy of Inscriptions and Medals, I663. Rerum Gestarum Fides: Fidelity to Great Deeds [History]. Courtesy Cabinet des Médailles, Bibliothèque Nationale.

I. Antoine de Ratabon (I6I7-I670) held the title of Superintendent-Director General of Buildings, Arts, and Manufactories. Although Colbert became Superintendent of Finance in I662, he did not succeed Ratabon as Superintendent of Buildings until I January I664. 
achieved, and which he foresaw would be followed by deeds even greater and more noteworthy. All these exploits would be commemorated, along with the princely entertainments such as feasts, masquerades, carousels, and other similar diversions. So that these events might be described and illustrated with wit and understanding, and then circulated in foreign countries, where the way in which they are handled does nearly as much honor to the King as the deeds themselves, Monsieur Colbert decided to bring together several men of letters and keep them by his side. Their role would be to advise him on these matters and to form a kind of small council to deal with everything concerned with literature.

He had already cast his eye upon Monsieur Chapelain, ${ }^{2}$ whom he knew, as he did me the honor of telling me more than once, to be the man with the best taste and the soundest judgment for these things; Monsieur the Abbé de Bourzéis, ${ }^{3}$ whom he had known for a long time as a prodigy in science and literature; and Monsieur the Abbé de Cassagnes, 4 who had earned his respect and goodwill with a poem in which Henry IV gives advice to his grandson the king.

He was now lacking a fourth person, since he had determined that this group should have at least four members. To find one, he sought help from Monsieur Chapelain, who, on his own initiative and without my knowing anything about it, brought me to Monsieur Colbert's attention with praise which was far beyond anything I deserved. Monsieur Colbert asked him if I was the brother of the Receiver General of Finances, and if I was the one who had written two odes, one on the recent peace treaty and one on the King's marriage.s When Monsieur Chapelain answered yes, Monsieur Colbert said, "I am already very happy with his poetry, and Monsieur the Cardinal [Mazarin] took great pleasure in reading the odes during his voyage; but it would be good for me to see something of his prose." 6

They decided that Monsieur Chapelain would ask me, presumably of his own volition, to write a piece in prose on the King's recent acquisition of Dunkirk. I wrote it just as you have read it in the first collection of my writings. 7 It pleased

2. Jean Chapelain (I595-1674) was a poet and founding member of the French Academy who enjoyed enormous respect as an authority on esthetic matters, despite criticisms of his epic poem La Pucelle (The Maid of Orleans), published in 1656 . On 18 November 1662, he had written to Colbert, in reply to the "plans which you have done me the honor of communicating to me" regarding the creation of commemorative medals (Lettres, instructions et mémoires de Colbert, ed. Pierre Clément, 5:587).

3. Amable de Bourzéis, Abbé de Saint-Martin-de-Cores (1606-1672), another founding member of the French Academy, was known as an eloquent orator and adviser to the King.

4. Jacques Cassagnes (1635-I679), a poet and King's librarian, had only recently been elected to the French Academy, at the age of twenty-seven.

5. The odes Sur le mariage du roy (On the King's Marriage) and Sur la paix des Pyrénées (On the Treaty of the Pyrenees) were published separately in 1660 (Paris: C. de Sercy).

6. Colbert wrote to Cardinal Mazarin on 16 March 1660: "Since your Eminence has been pleased by the ode which I sent, and desires to know the name of its author, it is Perrault, a lawyer in Parliament, who has a certain genius and writes very good verse" (Lettres, instructions et mémoires de Colbert, 1:440).

7. This first collection was entitled Recueil de divers ouvrages en prose et en vers (Paris: Coignard, 1675), and it contains the prose Discours sur l'Aquisition [sic] de Donkerque par le Roy, en l'année 1663, pp. 88-98. The actual treaty in which England ceded its authority over Dunkirk to France, in exchange for a considerable sum of money and guaranteed rights of passage, was signed in London on 27 October 1662. 
them, and on the third day of February I663, Monsieur Chapelain and I met at the house of Monsieur Colbert, as we had been ordered. We were led to a room where we found Monsieur the Abbé de Bourzéis and Monsieur the Abbé de Cassagnes, who had also been summoned, and where Monsieur Colbert came to find us. First of all, he asked us to maintain secrecy about what he was going to say, and then he announced why he had brought us there. It was to form, as I have said, a kind of small council which he could consult on all matters concerning buildings, and where wit and learning might be required. He desired us to meet at his house twice a week, on Tuesdays and Fridays.

This last day was chosen because he had no council meetings, and he used it as a day of rest, or rather to work on other things besides current business. Monsieur Colbert scarcely knew any form of rest other than that of changing tasks, or going from a difficult task to one which was a bit less so.

He wanted us to begin working in his presence on that very day, and that meant putting in writing what he had just told us. I was chosen to take up the pen, which always stayed with me thereafter. He left us then to go see the King, and when he returned, upon finding us still there, he approved what we had written and ordered me to keep a register of everything that would be done and resolved in the future.

On the following Isth of February, an agent of Monsieur Colbert brought me a nice purse in which there were five hundred écus in gold; this gratuity continued, increasing by five hundred livres in 1669 and remaining at that level until $1684 .^{8}$

\section{MEDAL OF THE TREATY WITH THE SWISS}

During that time, the Swiss had just arrived in Paris to renew their treaty with France. 9 It was necessary to make a medal honoring this, and this was the project which our fledgling Academy undertook. Monsieur the Abbé de Bourzéis was the one who played the greatest role, because the verse which serves as its legend was all his: "Nulla dies sub me natoque haec foedera rumpet."

8. The value of a livre was one franc, and an écu was equivalent to three francs; Perrault's pension therefore totalled two thousand francs in 1669 . According to the official register of Gratifications given to men of letters by Louis XIV, compiled by Pierre Clément from the Mélanges Colbert, vol. 3II (see Lettres, instructions et mémoires de Colbert, 5:466), Perrault received fifteen hundred livres in I664, "en considération de ses belles-lettres" (belles-lettres: writings appreciated for their aesthetic merit). In the list of fifty-eight names, the exact same sum and wording are listed only for Chapelain and Cassagnes; dans les belles-lettres" ("a great theologian, well versed in letters"). In subsequent years, Perrault was often listed second or third on the gratifications register, after Chapelain and/or Bourzéis; this fact hould seem to support his claim to membership in the Little Academy, although later sources dispute his status. The pension was actually terminated in 1682 , the same year that Perrault was forced to resign as superintendent of buildings.

9. Henri IV's treaty with the Swiss had expired in May I65I, and a new accord was signed on 4 September 1663 .

IO. In Latin, "Never shall this treaty be broken by me or by my descendants." 


\section{DEVICE FOR MONSEIGNEUR THE DAUPHIN}

A few days later, Monsieur Colbert requested a personal device for Monseigneur the Dauphin, who was still only three or four years old. I had the felicity of creating one which was received more favorably than several others. The face of it has a thunderbolt issuing from a cloud, with these words: Et ipso terret in ortu. ${ }^{11}$ It was placed on the banners of the Dauphin's regiment and on the helmets of his guards.

\section{CORRECTION OF WORKS WRITTEN IN HONOR OF THE KING}

When there was no commissioned task, the Academy worked upon the revision and correction of the various works, either in prose or in verse, which were composed in praise of the King, to put them in shape for publication by the Royal Printers. We corrected enough to form a very thick volume, and I handed over the manuscripts of these works, which filled two very large envelopes. ${ }^{12}$ Each one of us in this Little Academy also worked on his own, writing individual works about the great deeds of His Majesty.

\section{TAPESTRIES OF THE FOUR ELEMENTS}

Monsieur Colbert asked us to produce designs for some tapestries which were to be made by the Gobelins weavers. We gave him several, among which he chose one depicting the four elements, where a way was found to introduce several motifs glorifying the King. Since these tapestries can be seen every day and have been reproduced on plates with accompanying descriptions, making up a very beautiful volume, I will say no more about them. I will simply observe that all the legends were written by me. I would not say this to anyone but my own children.

Nor would I mention to anyone else what I am about to describe. When we submitted forty-eight legends to Monsieur Colbert for these tapestries, including sixteen by the Abbé de Bourzéis, sixteen by the Abbé de Cassagnes, and sixteen of my own making, we mixed them all together, so that he might choose the sixteen which he preferred without knowing their author. Fourteen of my legends were found to be worthy of his choice. In the joy that this caused me, I could not prevent myself from telling him of this circumstance. He then asked me which were the two other devices of mine that he had not chosen. When I pointed them out, he said:

II. The Dauphin, Louis le Grand (I66I-I7II), had been born on I November I66I and would in fact have been about two years old. The motto "He terrifies even from birth" is a play upon the Latin verb terrere, which means both to terrify and to strike with awe or admiration.

12. The Bibliothèque Nationale has no holdings of works published by Perrault between 1662 and 1668. The works he describes here, having been commissioned as panegyrics of the King, may have been deposited in the Bibliothèque du Louvre, and therefore destroyed in the fire of $187 \mathrm{I}$. 
"These two seem to me to be as good as the two I took in their place; they should be put with the rest, so that the legends will all be yours."

\section{TAPESTRIES OF THE FOUR SEASONS}

We then designed the hangings of the four seasons, modeled after the ones of the four elements; this design has also been engraved, and accompanied by similar descriptions. Of the sixteen legends which ornament these hangings, nine of them are mine. The truth is that I have a talent for writing legends, and I believe that over fifteen or sixteen years, I alone wrote as many as all the others put together. There is a collection of them which may be found among my papers, appended to an essay on legends. ${ }^{13}$

Monsieur Colbert's intention was for us to work on a History of the King, and to this end he had me write down, in the register which I have just mentioned, several things that the King said, so that they might be incorporated into the History. Among others, I remember this one.

One day, in the presence of Monsieur de Villeroy, ${ }^{14}$ Monsieur Le Tellier, ${ }^{15}$ Monsieur de Lionne, ${ }^{16}$ Monsieur the Marshal de Grammont, ${ }^{17}$ Monsieur Colbert, and several others whom I do not recall, the King said: "You are all my friends, and the subjects whom I hold in the greatest affection and trust. I am young, and women usually exert a great deal of power over men of my age. I order you all, that if you observe a woman, whoever she may be, gaining control over me and governing me to the slightest extent, you must warn me. I will want only twenty-four hours to rid myself of her and to satisfy you on that score."

Monsieur Colbert also had me write down the most important actions of His Majesty, those which were either little known to the public, or of which the causes and circumstances were known only to Monsieur Colbert. I remember that he dictated to me the whole business about Monsieur Fouquet ${ }^{18}$ from one end to the

I3. A manuscript by Perrault entitled Devises pour les tapisseries du roy is owned by the Bibliothèque Nationale (f.f. 7819).

I4. Nicolas de Neufville, Duke de Villeroi (I598-I685), was a Marshal of France and the tutor of
Louis XIV.

Is. Michel Le Tellier (1603-I685) was a prominent statesman whose duties included service as Secre-

tary of State for War; his son the Marquis de Louvois later succeeded Colbert as Superintendent of Buildings.

16. Hugues de Lionne, Marquis de Berny (16II-I671), served as Minister of State in I659 and became

Secretary of Foreign Affairs in 1663.

I7. Antoine, Duke de Gramont (1604-1678), was a Marshal of France and had also served as Minister of State (1653).

18. Nicolas Fouquet (1615-1680) preceded Colbert as Superintendent of Finance, and despite his undisputed acumen, Fouquet's power and wealth threatened the absolute authority of the young King, who began his personal reign after the death of Mazarin in 166r. According to tradition, it was an invitation to Fouquet's lavish estate at Vaux-le-Vicomte which provoked Louis XIV into ordering the Minister's arrest in I66I, but in fact Colbert had been working to achieve Fouquet's downfall for some
time previously. 
other, and that by his order I revised it three or four times before transcribing it into my register.

I forgot to mention that shortly after he convened the Little Academy, he took us to make our bows to the King. This was during the time when the Queen Mother was ill with the disease from which she died. ${ }^{19}$ The King was in a small dressing room behind the Queen's chamber, and he went in to see her constantly, seeing to almost all her needs, either giving her something to drink, or bringing her broth; no son has ever honored his mother more during his whole life.

\section{THE KING'S REPLY TO THE LITTLE ACADEMY}

After Monsieur Colbert introduced us to the King, the King uttered these words:

"You may judge, Messieurs, of my respect for you, since I am entrusting you with the one thing in the world which is most precious to me: my honor and reputation. I am sure that you will work wonders; for my part, I will attempt to furnish you with material worthy of use by men as clever as you."

Sometime later, Monsieur Charpentier, ${ }^{20}$ of whom Monsieur the Abbé de Bourzéis and Monsieur Chapelain had spoken highly to Monsieur Colbert, was named to this Little Academy. We all looked to him to write the history of the King, that is, to serve as recording secretary, because the whole group would be working on its revision and correction. ${ }^{21}$ When the question arose of how he should proceed, we told him that he should make use of news gazettes and everything which could be gleaned from the public to form the basis for his history; then, whenever he produced something noteworthy, and it had been reviewed by the Academy, Monsieur Colbert would add or delete whatever he thought necessary.

\section{METHOD OF APPROACH TO THE HISTORY OF THE KING}

In order to facilitate our task, I proposed an expedient which was as follows. Whenever Monsieur Charpentier would write the equivalent of a small notebook, and that notebook would be revised by the group, he would send it to Monsieur Colbert in a packet to be placed on his desk, along with the other packets of letters which he received in a constant stream. In this way, reading this notebook would distract him from the reading of the other letters, and by writing in the margins or between the lines whatever he deemed fit to add, or by crossing through whatever it

19. Anne of Austria (160I-1666), the widow of Louis XIII, had acted as regent from 1643 to I66I, with the guidance of Cardinal Mazarin. She died of cancer on 20 January 1666.

20. François Charpentier (1620-1702) had been a member of the French Academy since I650.

21. In the Histoire de l'Académie Royale des Inscriptions et Belles-Lettres (Amsterdam, 1719), Charpentier was listed not as the fifth but as the fourth official member of the Little Academy, and Perrault was described as a recording secretary, not named as an official member until the death of Cassagnes in 1679. 


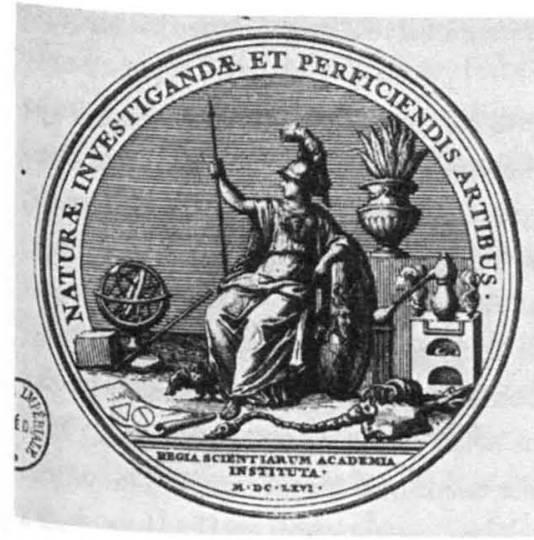

Medal commemorating the foundation of the Academy of Sciences, I666. Natura Investigada et Perficiendis Artibus: To Investigate Nature and to Perfect Skills. Courtesy Cabinet des Médailles, Bibliothèque Nationale.

was necessary to delete, the thing would be done without either consuming a block of time or being a separate task on top of all the others. Monsieur Colbert was much in favor of this expedient, but Monsieur Charpentier would never accept it, always insisting that Monsieur Colbert write him memoranda and speak to him privately about confidential matters. Monsieur Colbert did not have time for this, and never did it. So, that is where things stood.

That was a great loss for the Little Academy and a boon to Monsieur Pelisson, ${ }^{22}$ and particularly to Messieurs Racine and Despréaux, ${ }^{23}$ who were later given the task of writing the King's history by Madame de Montespan. ${ }^{24}$ She regarded this project as an amusement which she needed for entertaining the King. At various times, these gentlemen were rewarded very generously.

\section{ESTABLISHMENT OF THE ACADEMY OF SCIENCES}

Monsieur Colbert, once having formed this Little Academy, thought of establishing a larger and more important one for the advancement and improvement of all the sciences. First he had a list compiled of all the learned men who used to meet in those days at the home of Monsieur de Monmort, ${ }^{25}$ a Councillor of State. This man was a great admirer of all the sciences and of all scientists, as well as all persons who were

22. The writer Paul Pellisson (1624-1693), who had been imprisoned for having defended Fouquet,

was named to the French Academy in 1652 and was charged with writing its official history.

23. The dramatist Jean Racine $(1639-1699)$ and the satirical poet Nicolas Boileau-Despréaux

$(1636-17 \mathrm{II})$ were both named King's historiographers in October 1677. Both writers were bitterly opposed to Perrault in the later Quarrel of the Ancients and Moderns.

Louis Xrançoise Athénaïs de Rochechouart, Marquise de Montespan (1640-1707), was the mistress of 25. XIV from 1667 to 1684 , during which time she bore him eight children.

of the Henri-Louis Habert, Seigneur de Montmor et du Mesnil (1600-1679), was a founding member which French Academy who held weekly meetings at his home at No. 7 Rue Vieille-du-Temple, at sions scientists would gather to discuss various subjects, primarily questions of physics. These sessovided a model and inspiration for the Academy of Sciences. 
reputed to be extraordinarily clever in some branch of knowledge, either in our own kingdom or in foreign countries.

Monsieur Colbert consulted in particular with Monsieur Chapelain, Monsieur the Abbé de Bourzéis, and Monsieur de Carcavi ${ }^{26}$ about the selection of members. Here are the names of those who were among the first chosen: Messieurs Carcavi, Roberval, Huygens, Frénicle, Picard, Duclos, Bourdelin, de la Chambre, Perrault, Auzout, Pecquet, Buot, Gayant, Mariotte, and Marchand. ${ }^{27}$

I had considerable difficulty in making your uncle agree to join this Academy, not because he did not feel honored to have been considered, but because, he said, he did not have the qualities required for being put with so many excellent men. This modesty was sincere, although he alone had the talent of ten other men. The whole family, which agreed with me and spent several days pressing him on the issue, had a difficult time making him decide to do it.

Later, Monsieur Duhamel, the Abbé de Saint-Lambert, ${ }^{28}$ was admitted into the Academy, his merit having been recognized from the translation he made into Latin of the Rights of the Queen, as I will describe further on. Monsieur the Abbé de Galois $^{29}$ followed him; my brother the physician had suggested his name to Monsieur Colbert for the post of Colbert's librarian, and that is how he entered the Academy.

Monsieur Blondel, ${ }^{30}$ who later tutored Monseigneur the Dauphin in mathematics, was the next to enter, and I was the one who proposed him.

26. Pierre de Carcavi (1603-I684), a geometrician, was also in charge of the King's Library, though without an official title.

27. Gilles Personne de Roberval (1602-I675), geometrician and professor of mathematics; Christian Huygens (1629-1695), Dutch-born physicist and astronomer, discovered the ring of Saturn and the Orion nebula, established the theories of light waves and pendulum movement, and invented the spiral watchspring; Bernard Frénicle de Bessy (I600-I675), geometrician; Abbé Jean Picard (1620-I682), considered the greatest astronomer of his time, used lenses to create the first instruments for precise astronomical and geodesic measurement, and in 1669-1670 made one of the first accurate analyses of the dimensions of the earth; Samuel Cottereau Duclos (d. 1715), King's ordinary physician; Claude Bourdelin (I62I-I699), chemist; Marin Cureau de la Chambre (I596-I669), writer, botanist, and King's ordinary physician, who was also a founding member of the French Academy; Claude Perrault; Adrien Auzout (I630-I69I), architect; Jean Pecquet (I622-I674), physician, professor of the University of Montpellier, and former friend of Fouquet; Jacques Buot (d. r673), cosmographer, King's engineer, and mathematics tutor for the pages in the Grand Stables; Louis Gayant (d. I673), military surgeon; Abbé Edme Mariotte (1620?-1684), a physicist who discovered Mariotte's Law in 1676 (that the volume of a gaseous mass varies in inverse proportion to its pressure); Nicolas Marchant (d. I678), physician, botanist, and director of the Royal Botanical Garden.

28. Jean-Baptiste Duhamel, Abbé de Saint-Lambert (1624-1706), astronomer, physicist, and theologian who was named the first Perpetual Secretary of the French Academy in 1666.

29. The Abbé Jean Galloys (1632-I707) was a professor of Greek and a cofounder and editor from I665 to 1674 of the Journal des savants, considered to be the first scholarly journal and the oldest journal still published. He was elected to the French Academy in 1672, upon the death of the Abbé de Bourzéis, and was also a member of the Academy of Inscriptions.

30. François Blondel (16I8-1686), prominent architect and professor of mathematics, became director of the Royal Academy of Architecture (founded in 167I) and a Councillor of State. He authored the Course in Architecture Taught at the Royal Academy of Architecture (1675-1683), an important document of the formal classical style. 
Monsieur de Cassini ${ }^{31}$ was proposed at about that time by Monsieur de Carcavi, who brought him from Bologna, Italy, where he was a professor, and had him given a pension of nine thousand livres, which he still enjoys. Monsieur de Carcavi hoped to have him as a son-in-law, but that plan did not succeed, and Monsieur de Cassini contracted another alliance elsewhere.

Monsieur Dodart, ${ }^{32}$ who was proposed by my brother the physician, was received shortly afterwards.

With respect to Monsieur du Vernay, 33 he was only named after the death of Monsieur Gayant, the surgeon, in order to take his place in performing dissections. It was my brother who nominated him and who aided him with his own influence, money, and even knowledge, so that he would straightaway be worthy of the post. 34 At about the same time, Monsieur de la Hire 35 was also received into the Academy.

Aside from the men whom I have just named, who held the first seats in the Academy, there were others of a lesser category who were only there to listen and to carry out the resolutions of the company, and in particular to conduct the experiments which were needed. Among these were the Sieur Richer, ${ }^{36}$ who went to the Isle of Cayenne to make observations, and the Sieur Niquet, 37 who was in charge of constructing models and machines. These machines were either of old design, such as the pump of the Pont-Neuf, cranes, engines, windmills, etc., or of new invention, such as machines for cleaning harbors, sawing through stones, making silk stockings or ribbons, etc. There were several more of these students whose names escape my memory. The Sieur Couplet ${ }^{38}$ was named as the group's bailiff, and later he was made the custodian of the Observatory when they began its construction.

It was decreed that the Academy would concern itself with five principal things: mathematics, astronomy, botany or plant science, anatomy, and chemistry. Monsieur Roberval, Monsieur Frénicle, Monsieur Huygens, and Monsieur Blondel devoted themselves particularly to questions of mathematics; Monsieur de Cassini, Monsieur

3I. Jean-Dominique Cassini (1625-1712), Italian astronomer who was naturalized as a French citizen in 1673 .

32. Denis Dodart (1634-1707), King's physician and professor of pharmacy, who was admitted to the Academy of Sciences in 1673 as a botanist.

33. Guichard-Joseph-Pierre Du Verney (1648-1730), professor of anatomy, was admitted to the Academy in 1676 .

34. Claude Perrault himself performed many dissections, which were an important part of scientific studies at the time, and the cause of his death in 1688 was an infection contracted after the dissection of a diseased camel.

35. Philippe de la Hire (1640-I7I8), professor of mathematics, was admitted to the Academy in 1678 as an astronomer.

36. Jean Richer (1630-1696) published the Astronomical Observations and Critiques Made on the Island of Cayenne in 1679 .

37. Antoine Niquet is listed in the register of Gratifications for 1666 , receiving a pension of eight livres. ives.

38. Claude-Antoine Couplet (1642-1722), hydraulic engineer, appears in the list of Gratifications for

1668, receiving only six hundred livres for being "in charge of the academy's research on animals." He was named Treasurer of the Academy of Sciences in 1696. 
Auzout, and later Monsieur de la Hire took astronomy as their share; Monsieur de la Chambre, Monsieur Perrault, Monsieur Gayant, and later Monsieur du Vernay worked on anatomy; Monsieur Duclos, Monsieur Bourdelin, and later Monsieur Borel 39 were in charge of chemistry; and Monsieur Dodard and Monsieur Marchand devoted themselves to the study of plants and everything concerned with botany. Monsieur du Hamel was at first the secretary of the company; later, when Monsieur Colbert de Croissy ${ }^{\circ}{ }^{\circ}$ sent him to England as an Ambassador, Monsieur the Abbé de Gallois took on this function. When Monsieur du Hamel returned, he resumed his post and still occupies it today.

Monsieur the Abbé de Bourzéis requested that there be academicians for theology, and since Monsieur Colbert agreed to this, several doctors of theology were named. Among others, there was the renowned Monsieur Ogier, ${ }^{4 I}$ most famous preacher of his time, who, after having charmed Paris, made himself much admired in Germany, where Monsieur d'Avaux the Ambassador had brought him as a friend. This Monsieur Ogier had a brother, also quite famous, who wrote a very elegant account of his travels in the North, under the title of Iter Danicum. ${ }^{2}$ They had two sisters of extraordinary merit who were good friends of our whole family.

The theological meetings only lasted a short time, because the Sorbonne became alarmed and sent deputies to complain to Monsieur Colbert. He gave in to their remonstrances, as he could not deny that there was danger in allowing private individuals to dispute matters of religion, which should be left in the hands of the Faculties established for the purpose of knowing about these things.

At the same time, it was resolved that in the Academy's study of the sciences which I have mentioned, there should be no discussions of anything controversial or political, because of the peril involved in stirring up these things without purpose or need. It was also decreed that the astronomers should not study astrology, and that the chemists should not work on the Philosopher's Stone, ${ }^{43}$ neither closely nor from afar, since these two subjects were deemed to be quite groundless and quite pernicious.

\section{REWARD FOR THE MEN OF LETTERS}

This Academy had not yet been completely set up when Monsieur Colbert established a fund in the amount of one hundred thousand livres from the budget of the

39. Pierre Borel (1620-1689), King's physician, was admitted to the Academy of Sciences in 1674 .

40. Charles Colbert, Marquis of Croissy (1629-1696), was the Minister's younger brother. He served as a Councillor of State and was named Ambassador to England in 1679.

4I. François Ogier (d. 1670) was listed in the Gratifications for I66s as receiving fifteen hundred livres "in consideration for his profound knowledge of theology."

42. Charles Ogier (1595-1654) was the secretary to the Count d'Avaux, Ambassador to the Northern Courts. A journal of his travels, Ephemerides sive iter Danicum, Suecicum, Polonicum, ... (Accounts or Journey to Denmark, Sweden, Poland, ... ) was published posthumously in I656.

43. In alchemy, the philosopher's stone is the substance believed to have the power of transmuting base metals into gold. 
King's buildings to be distributed to men of letters. Whoever was distinguished for eloquence, poetry, physics, or other sciences, either in France or in foreign countries, received an annuity; some received I,000 écus, others 2,000 livres, others 500 écus, still others I,200 livres, some I,000 livres, and the least important ones 600 livres. These pensions went to Italy, Germany, Denmark, Sweden, and to the furthest extremities of the North; they went as letters of exchange and, in the case of those distributed in Paris, they were delivered to the recipients in the first year by a clerk of the treasurer of buildings, in the most beautiful purses of silk and gold.

In the second year they were delivered in purses of leather, and since nothing remains in the same state forever and everything tends naturally to decline, in the following years the recipients had to go to the treasurer themselves to receive the sum in ordinary currency, and the "years" began to last for fifteen and sixteen months.

When war was declared with Spain,44 a great number of these annuities were canceled, and there were scarcely any left besides those of the Little Academy and the Academy of Sciences, a situation which continued and still continues today. Your uncle the physician always had an appointment of 2,000 livres, as a member of the Academy of Sciences, not counting the rewards he received for working on the designs of the Louvre, the Observatory, and the Arch of Triumph, as well as several works at Versailles, as I will tell you in the proper place.

It was resolved that the Academy of Sciences would meet in the King's Library, in a low room where it still meets, and that meetings would be held twice a week, on Wednesdays and Saturdays.

\section{ESTABLISHMENT OF A CHEMICAL LABORATORY IN THE BUILDING HOUSING THE ROYAL LIBRARY}

Two things appeared to be necessary in order for the Academy to begin work and to fulfill the goals which were expected of it: a chemical laboratory and an astronomical observatory. Monsieur Colbert ordered that a laboratory be set up in whichever part of the library building would be most suitable and that the plans and drawings provided by Monsieur Duclos be followed. He also ordered that it be furnished with all the tools, utensils, drugs, and vessels needed for the experiments which would be deemed appropriate to carry out.

\section{THE OBSERVATORY BUILDING}

The gentlemen of the Academy were instructed to examine possible sites for the construction of an observatory. They cast their eye at first upon Montmartre, as a

44. Although hostilities with Spain were frequent throughout Louis XIV's reign, Perrault may be referring here to the conflict from 1682 to 1684 between France and the coalition of Spain and the Holy Roman Empire. The total of Gratifications distributed was reduced from 63,022 livres in 1682 to 32,549 livres in 1683 (Lettres, instructions et mémoires, 5:496-98). 


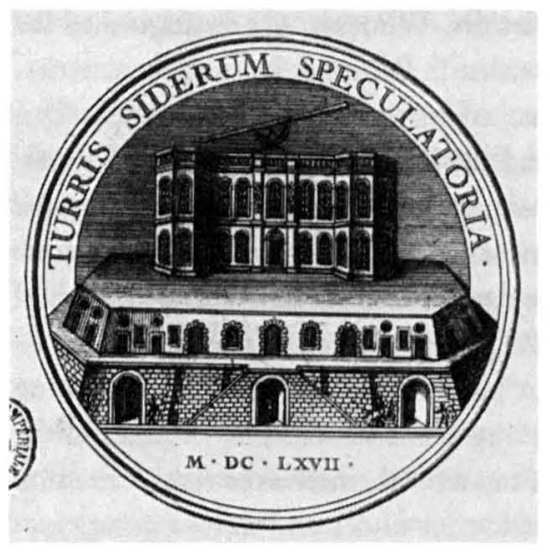

Medal commemorating the construction of the Observatory designed by Claude Perrault, 1667. Turris Siderum Speculatoria: Tower for Observation of the Heavenly Bodies. Courtesy Cabinet des Médailles, Bibliothèque Nationale.

place where one could easily distinguish the entire horizon; but it was found that all the smoke of Paris, which is in the middle of that mountain, was a perpetual obstacle to any kind of observation. After having studied the immediate surroundings of Paris, no site was found to be more suitable for that building than the one where it was actually constructed. 45 It has Paris to the north, where there are no observations to be made, it faces the noonday sun, and it has an unrestricted view of the horizon from the point of summer sunrise and beyond, to the point of summer sunset and even further. Your uncle was ordered by Monsieur Colbert to make a design for this observatory, which he then approved wholeheartedly. It would have been carried out without a single change, if not for the fact that when Monsieur de Cassini arrived in France, Monsieur Carcavi wanted to promote the success of his friend, and put it into Monsieur Colbert's mind to make some changes.

\section{CHANGES IN THE OBSERVATORY PLANS AFTER THE ARRIVAL OF MONSIEUR DE CASSINI}

Monsieur Le Vau, 46 the King's First Architect, was irked that someone else was producing building designs, and he pressed in favor of Monsieur de Cassini's idea. This was to change the plan of the main upper floor by making a large room, which he claimed was necessary for an observatory. Your uncle tried in vain to explain that this could not be done without either raising the height of the building, which was impossible since the great cornice stones were already laid, or greatly lowering the

45. The observatory was constructed in what is now the 14 th Arrondissement of Paris, on the Rue du Faubourg Saint-Jacques.

46. Louis Le Vau (16I2-I670), appointed King's First Architect, had created Vaux-le-Vicomte for the deposed minister Fouquet. He designed numerous important buildings, including the College of the Four Nations (1663), now known as the Institut de France and the present home of the French Academy. 
vaulted ceiling of that large area. That would be very inconvenient, for it would reduce by half the well of the great staircase, changing it from being very beautiful and magnificent to being severe and unpleasing. Besides, this large room seemed completely unnecessary, for the room originally planned was more than sufficient.

It was necessary to accept the opinion of Monsieur de Cassini and Monsieur Le Vau, and a kind of small attic had to be added above the great cornice, to give more height to the building. The stairway was spoiled, and the large room has never been used for any of the experiments for which it was deemed necessary. It even happened that because that room was made too large, the vaulting crumbled, as did the main structure, and they had to rebuild both the vault and the cap of cement above. It seems that there will always be something which has to be done to that vault. This was a great error, and one to which your uncle never consented.

Monsieur de Cassini had yet another stubborn notion, that he did not want representations of the twelve signs of the zodiac, in marble and mosaics, although Monsieur Colbert had agreed to this, and it would have been very beautiful. This objection, which no one has ever understood, prevented the room from ever being completely inlaid in marble, for the wars which came later brought an end to this kind of expenditure.

Monsieur de Roberval, who disliked Monsieur de Cassini and who viewed him as his rival in mathematics, has said jokingly that because of Monsieur Carcavi's anxious desire to promote the opinions of Monsieur de Cassini, Monsieur Carcavi resembled a squire, wanting to show off the horse that he puts in his master's stable.

When they began building the observatory in the month of March of the year 1667 , they had already begun working on the Louvre. What happened concerning that building is very curious and of very great importance, and that is why I will take up the story from its very beginning.

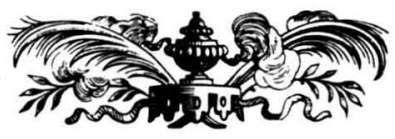




\section{Part 3 \\ THE LOUVRE}

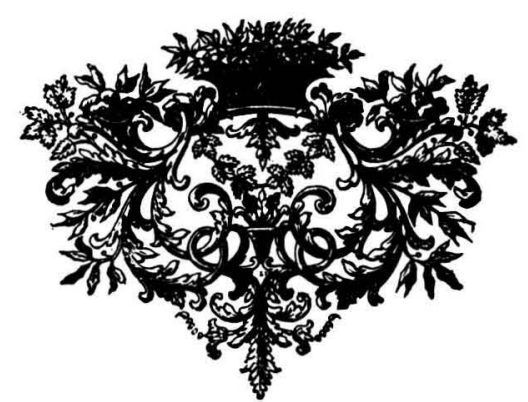

WHERE WORK BEGAN UPON THE LOUVRE

When Monsieur Colbert was made Superintendent of the King's Buildings, or at least when people began to pay him their respects for this in public, which was on New Year's Day of I664, not only were the foundations laid for the principal side of the Louvre, but a part of this façade had been built up to eight or ten feet above ground. This had been built under the orders of Monsieur de Ratabon, the previous superintendent, and according to the designs of Monsieur Le Vau, the First Architect.

\section{THE PARISIAN ARCHITECTS ARE INVITED TO CRITIQUE LE VAU'S DESIGN AND TO SUBMIT THEIR OWN}

Monsieur Colbert was not happy with this design, and he considered it a matter of honor and capital importance that the palace be given a façade worthy of the prince who was having it built. He began by asking all the architects in Paris to examine Monsieur Le Vau's design, and he invited them to come and view the wooden model, in a room where it was displayed for all eyes to see. ${ }^{I}$ At the same time, he invited these same architects to make designs for this façade, promising to carry out whichever one was the most appropriate, and the most appealing to the King's taste.

Almost all of the architects condemned Monsieur Le Vau's design, in written critiques which they submitted to Monsieur Colbert. Several of them even brought designs of their own invention, which were displayed in the same room with Monsieur Le Vau's wooden model.

Your uncle made a design more or less identical to the one he later submitted, and which was ultimately carried out. Monsieur Colbert, to whom I showed it, was

I. The Buildings Accounts for 1667 list a payment of 819 livres to the master woodworker Antoine Saint-Yves, for "woodworking he performed for the model of the Louvre from the design of Monsieur Le Vau" (Comptes des Bâtiments du roi, ed. Jules Guiffrey [Paris: Imprimerie Nationale, I88I], I:185). 
fascinated, and could not understand how a man who was not an architect by profession could make such a beautiful thing. This design, which is in two parts, one geometric and another in perspective, is in two plain wooden cases inside the large cupboard in my storeroom. The idea of the peristyle ${ }^{2}$ was mine, and when I shared the notion with my brother, he approved it and put it into his design; but he gave it the infinite embellishment of which he was so capable.

\section{DESIGN BY MONSIEUR PERRAULT THE PHYSICIAN, PUT ON DISPLAY AND CRITIQUED WITH THE OTHERS}

This design was displayed like the others; it was a pleasure to see the judgments which this design received. It was considered very beautiful and magnificent, but no one knew to whom it should be attributed. Those who were well versed in these matters knew of no one, aside from some foreigner whom they mentioned, who could draw so well and so accurately.

Monsieur Colbert, although he was very pleased with your uncle's design, did not feel that he should let it go at that; not wishing to omit anything in a matter of such consequence, he resolved to seek the advice of Italy's foremost architects, and to invite them, as he had the French, to submit designs.

\section{MONSIEUR LE VAU'S DESIGN IS SENT TO ROME TO BE EXAMINED}

Copies were made of Monsieur Le Vau's design, and sent to Rome addressed to Monsieur Poussin, the King's Ordinary Painter and one of the most excellent artists of that time. 3 Monsieur Colbert instructed me to write him a letter, which ran as follows:

Monsieur,

You shall know by this letter that the King holds your talents in particular esteem. As His Majesty has resolved to send the plans and elevations of his Louvre palace to Rome, to obtain the opinions and thoughts of her most celebrated architects, and, to this purpose, having need of a person who is very intelligent and very capable to make these inquiries on his behalf, he has found that the task could be placed in no better hands than yours. His Majesty considers not only that your perfect familiarity with painting and architecture render you eminently capable of this task, but also that your long residence in Rome, along with your personal merit, have no doubt attracted to you the friendship of her worthiest men; thus there is no one who is better able to glean from them their insights and opinions.

2. A series of columns surrounding a structure or enclosing a court; this feature was perhaps the the L imposing aspect of the design, inspiring the commonly known description of the east façade as the Louvre Colonnade.

3. Nicolas Poussin (1594-1665), renowned master of the seventeenth-century classical style in paint-

ing, spent most of his life in Rome. 
The discussion which accompanies the plans and elevations that I am sending you, and which gives their explanation, will suffice to inform you of the matters upon which these men should be consulted, and I shall merely touch upon a few observations regarding the manner in which I believe you should approach them.

I consider that before you call them together, it is necessary to see them each separately, to show them the designs and even to allow them some time in which to form their own ideas, in order to obtain the greatest diversity of their thoughts, and also so that each one might receive full credit for his inventions, without the reproach of having been assisted by someone else's advice. Then, it would be good to bring them together, if possible, and to hear them approve or criticize each other's proposals, so that you may judge the general direction in which the group's opinion is leaning, and know which plan would be the most generally acceptable.

I place no limit upon the number of persons whom you consult; you should take care only that the matter does not drag out too long, by indiscriminately allowing all kinds of persons to give their opinions; and on the other hand, you should take care not to forget anyone of great renown, such as Signore Pietro di Cortone, 4 Signore Reynaldi Areveti, 5 the Cavaliere Bernini, ${ }^{6}$ and others equally famous. You should ask them all to give their advice in writing, which I believe they will do willingly, since it is unlikely that they would be indifferent to the credit they would receive for having designed the most beautiful and superb palace in the world, or to the idea of seeing themselves given precedence, if their advice should be followed, over all the most notable architects of their century. But it is especially vital to make them understand that when they condemn something in the designs which they are sent, they must state their reasons; and similarly, when they wish to promote an idea or a design, they must found this either upon architectural logic or upon some important example.

This is how I think the matter should be handled; nevertheless, as there might be unexpected difficulties in using this approach, I entrust everything to your judgment, and I leave to you the choice of arrangements to follow in this business, which is without a doubt extremely important, since it concerns perfecting the most beautiful edifice in the world, and making it worthy, if possible, of the grandeur and magnificence of the prince who shall inhabit it.

I do not doubt, Monsieur, that the King's idea of finishing his palace has given you joy, since this plan clearly reveals the love which His Majesty has for all the fine arts in which you are skilled. It is certain that he intends to elevate these arts to the highest degree of perfection ever attained, and that he wishes for his reign to be celebrated not only for the great deeds of his own life, but also for the infinite number of famous men in every profession, who have equaled and even surpassed those of antiquity. To this purpose, His Majesty forgets nothing which may naturally encourage virtue in the hearts of those who have some inclination toward great things, and for his own part he offers them every means of improving themselves. To ignite

4. Pietro Berrettini da Cortona (1596-1669), considered a grand master of the baroque, had been commissioned to decorate several churches and royal palaces in Rome.

5. Perrault may have been referring to Domenico Rainaldi (1619-I698), a celebrated Roman painter and architect.

6. Gian (Giovanni) Lorenzo Bernini (1598-1680), a painter, architect, and perhaps the most famous sculptor of his day, was made an honorary Knight of the Cross (Cavaliere di Cristo) by Pope Gregory $\mathrm{XV}$ in 1621 . He had been invited to the French court as early as 1625 , but preferred to enjoy the patronage of the Vatican. 
interest in science, he has given monetary awards to all the men of letters who have outstanding reputations, and wherever merit shines forth, not only in France but in all of Europe, there have been tokens of his royal generosity. With respect to painting and sculpture, which His Majesty loves particularly, and which he views as two arts that should serve particularly to glorify him and to transmit his name to posterity, he omits nothing which may bring them to the last degree of perfection.

It was for this noble and praiseworthy motive that he established in Paris, a few years ago, a Royal Academy of Painting and Sculpture, 7 engaged teachers for the instruction of young people, offered prizes for the students, and gave to that assembly all the privileges it could ever wish to have. This institution has not been unfruitful: young people are being trained there who are very promising and who will one day become excellent masters. But, because it still seems necessary for young people of your profession to spend some time in Rome, to acquire the taste and manner of the originals and models of the greatest masters both of antiquity and of recent times, and since it happens often that those students who have the greatest talent and aptitude either fail to do this or cannot make the journey because of its cost, His Majesty has resolved to send a certain number of students there every year, who will be chosen from the Academy and who will be supported in Rome during their stay there. His Majesty believes also that it would be very useful for the advancement and progress of these young people if they could be directed by some excellent master, who would lead them in their studies, teach them the good taste and manner of the ancients, and make them perceive, in the works which they would copy, the secret and almost inimitable beauties which escape the eyes of most onlookers, and which are only discerned by the most clever.

To this end, His Majesty has decided to have always in Rome some illustrious master, who would have the care and direction of the students whom His Majesty will send there, and he has chosen you, Monsieur, and named you as the one whom he now entrusts with this charge. It is with this consideration and to this purpose that he has commanded me to present you with the sum of two hundred écus, which you will receive in the enclosed letter of exchange.

This, Monsieur, is what His Majesty has commanded me to write. I have no doubt that he will receive every satisfaction from you in the execution of the two important tasks with which he charges you. As for myself, I assure you that the honor which the King accords you gives me much joy, and that I will always feel this way when bringing equal joy to persons of your merit.

This letter, which should have been signed by Monsieur Colbert, was never sent, and I do not know the reason why. ${ }^{8}$ The designs were sent off and were seen in Rome by all the famous architects of that time, who all sent their own designs, but no one paid any attention to them. These designs were all very bizarre, and showed no taste for beautiful or judicious architecture.

7. The Royal Academy of Painting and Sculpture was founded in Paris in 1648 , with Charles Le Brun (see below, note 3I) named as its director for life. In 1656, it was granted a monopoly on the teaching of drawing.

8. The Academy of Painting in Rome was not officially established until 1666 , one year after Poussin's death. The Prix de Rome (Rome Prize) is still given. 


\section{RESOLUTION TO BRING THE CAVALIERE BERNINI TO FRANCE. THE KING'S LETTER TO BERNINI}

At this same time, there was a certain Abbé Benedetti9 in Paris, who had met Monsieur Colbert while acting as the steward of Cardinal Mazarin. Either because of his friendship with Bernini, or because the Cavaliere ingratiated himself by means unknown to me, this Abbé extolled Bernini's merits, placing him so far above all the other Italian architects that Monsieur Colbert decided to bring Bernini to France. Some people say that it was actually Cardinal Barberini ${ }^{\mathrm{to}}$ who was the first to praise the Cavaliere Bernini, followed by Monsieur de Bellefonds, ${ }^{\mathrm{II}}$ and that it was on the strength of their opinions that he was brought here.

Here are the letters that were written to him.

\section{LETTER FROM THE KING}

Seigneur Cavaliere Bernini, I have such esteem for your talent that I have a great desire to see and know such an illustrious person, provided that my wishes may accord with your services to Our Holy Father the Pope, ${ }^{12}$ and with your personal convenience. I have therefore sent this courier, by whom I beg you to grant me this satisfaction, and undertake the journey to France. A favorable occasion has presented itself with the return of my cousin and Special Ambassador the Duke de Créqui, ${ }^{13}$ who will inform you more precisely of the reason why I wish to see you and to discuss the beautiful designs which you have sent me for the Louvre. For the rest, I shall rely upon my cousin to convey to you my good wishes. I pray God that he keep you in his holy care, Seigneur Cavaliere Bernini.

Signed,

Louis.

\section{De Lyonner4}

At Paris, II April I66s

9. Elpidio Benedetti (1608-1690) had served as an intermediary between Bernini and Mazarin in 1645 , in an unsuccessful attempt to lure Bernini to France.

I0. Cardinal Antonio Barberini (1607-167I) was the nephew of the late Pope Urban VIII (Matteo Barberini, pope from I623 to I644), and held several important French appointments, including Bishop of Poitiers (I662) and Archbishop of Reims (1667). In 164I, Cardinal Richelieu had enlisted his assistance when commissioning Bernini to do a portrait bust of Richelieu, which was placed in the Cardinal's Palace (now the Palais-Royal) and was subsequently lost. Barberini was again appointed intermediary in October $\mathbf{1 6 6 3}$, when he issued another invitation to Bernini on behalf of Louis XIV.

II. Bernardin Guigault, Marquis de Bellefonds (1630-1694), was a Marshal of France and Master of the King's Household.

I2. Pope Alexander VII (Fabio Chigi, 1599-1667) had been pope since I65s. At the time of Barberini's invitation (October 1663), Bernini was engaged in constructing the colonnade of St. Peter's Basilica; in order to obtain his services, Louis XIV had to solicit the Pope's permission.

13. Charles, Duke de Créqui (d. I687), was the French Ambassador in Rome during a celebrated incident of 1662 , when his palace was fired upon by a mob and the Duchess's carriage was attacked. A formal apology was offered, and the event was commemorated in a medal, as well as in a tapestry now exhibited in the Popes' Palace in Avignon.

14. Marshal Hugues de Lionne (see Part 2, note I6). 


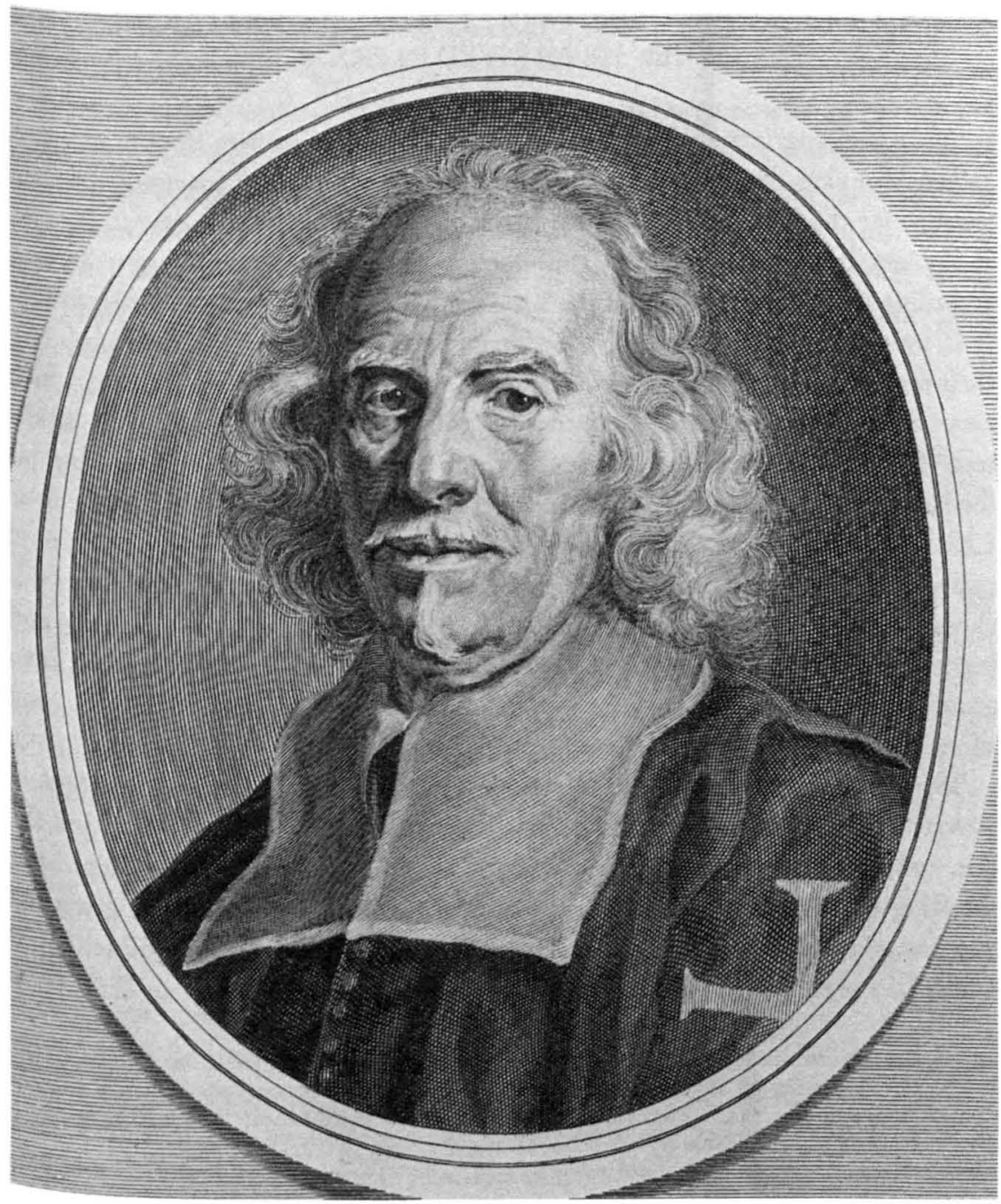

Gian Lorenzo Bernini. Engraving by Westerhout, after painting by Gaulli. Courtesy The Metropolitan Museum of Art, Gift of Mr. and Mrs. Stuart P. Feld, 1980 (1980.1124.5,6).

\section{LETTER FROM THE KING TO THE POPE TO OBTAIN THE SERVICES OF THE CAVALIERE BERNINI}

A more or less identical letter was written to the Pope and to Cardinal Chigi, ${ }^{15}$ and was carried by the Abbé Benedetti. ${ }^{16}$

I5. Flavio, Cardinal Chigi (I63I-I693), was the nephew of Pope Alexander VII.

16. The Abbé Benedetti had actually returned to Rome before 19 April 1664 , and by 20 April he had delivered Colbert's invitation to Bernini to submit a design. Bernini sent Colbert provisional plans in 


\section{HONORS BESTOWED UPON THE CAVALIERE BERNINI WHEN HE ARRIVED IN FRANCE}

It was something incredible to see the honors that the Cavaliere Bernini received. When Monsieur de Créqui took his leave of the Pope, colla solita pompa, ${ }^{17}$ he then went to see the Cavaliere Bernini, con la medesima ${ }^{18}$, to beg him to come to France; and when Bernini left Rome, ${ }^{19}$ the whole city was in a state of great anxiety, according to hearsay, for fear that the King would keep him in France forever.

In every city where he passed, the officials were ordered by the King to pay him their respects, and to bring him presents from the city. Even the city of Lyon, which never grants that honor to anyone but princes of the blood, acquitted itself like all the rest. ${ }^{20}$ There were officials sent from here, for the express purpose of preparing his food on the journey, and when he approached Paris, they sent ahead Monsieur de Chambray, who is also the Seigneur de Chantelou and the King's chief steward, ${ }^{21}$ to receive him and accompany him everywhere he went. Monsieur de Chantelou was chosen because he knew Italian quite well, because he had traveled to Italy and become friends with Bernini, and because he held Bernini in greater esteem than anyone could imagine. The Cavaliere arrived in France at the end of May, and Monsieur de Chantelou went ahead of him as far as Juvisy.

They lodged him first at the Hôtel de Frontenac, and Monsieur de Metz, ${ }^{22}$ steward of the Crown's furnishings, was ordered to furnish it for Bernini and his son, ${ }^{23}$ and other officials were brought in to cook for him and serve him. He greeted the King on the 4 th of June, I665, the feast of Corpus Christi, and was given the warmest reception imaginable. He had his designs laid out in a nicely appointed room where no one entered but himself, Monsieur de Chantelou, and Monsieur Colbert. A

July I664 and January I665, but after considerable correspondence it became clear that Bernini would have to supervise the work in person. On 23 April 1665 , Pope Alexander authorized Bernini to leave Rome for three months, to be at the service of the King of France (Léon Mirot, "Le Bernin en France," Mémoires de la Société de l'Histoire de Paris 3I [1904]: 195).

17. In Italian, "with the accustomed pomp."

I8. "With more of the same."

19. Bernini departed on 29 April and arrived in Paris on 2 June 1665.

20. The city of Lyon spent 278 livres to furnish an apartment in which Bernini would be received.

Louis XIV had already sent Bernini 10,000 écus (30,000 livres) to cover the expenses of his journey (Mirot, "Le Bernin en France," pp. 197 and 20I).

21. Paul Fréart, Sieur de Chantelou (1609-1694), misidentified here by Perrault as Monsieur de Chambray (who was Paul's brother Roland Fréart, 1606-1676), was Steward of Houses, Estates, and Finances for Monsieur, the King's brother (see below, note 69). Since Chantelou had spent considerable time in Italy as a friend of Poussin, Louis XIV sent him to accompany Bernini on the journey to France. Chantelou's diary of the events between 2 June and 20 October 1665 was not published until the end of the nineteenth century (Journal du voyage du Cavalier Bernin en France, ed. Ludovic Lalanne [Paris: Gazette des Beaux-Arts, I885]).

22. Gédéon Berbier, Sieur du Metz, was named Guardian of the Royal Treasury in 1663 and became Controller General of the Crown's Furnishings. He was a benefactor of the Academy of Painting, which named him an honorary member, and died in 1709 at the age of eighty-three.

23. Bernini traveled to France with his second son Paolo, who was eighteen, and two apprentices, a butler, and several servants. 
few other persons of rank, whom Monsieur Colbert wished to flatter with this honor, were also admitted.

After about two weeks, the Sieur Fossier, ${ }^{24}$ who had been ordered to provide the Cavaliere with everything he needed for drawing, told me that if I so desired, he would show me the Cavaliere's designs. I accepted his offer, and I saw the designs.

The next day, Monsieur Colbert asked me whether I had seen the plans. In that moment I made up my mind, without having thought about it in advance, to say that I had not seen them. I can assure you that this was the first and only time that I did not tell the truth to Monsieur Colbert.

"It's quite large," Monsieur Colbert told me.

"There are of course freestanding columns?" I asked.

"No," he said, "they are attached by one-third to the wall."

"The door is quite large?" I asked.

"No," he said, "it's no bigger than the door to the kitchen courtyard."

I said a few more things of this nature, calling to his attention the fact that the Cavaliere Bernini had fallen into the same errors for which Monsieur Le Vau and most of the other architects had been reproached. This had been my intention when I pretended not to have seen the Cavaliere's plans, because in that way my critique would carry much more weight. Besides, I would not perhaps otherwise have dared to express my opinions with such freedom. ${ }^{25}$

\section{BERNINI'S BUST OF THE KING}

As soon as he arrived, the Cavaliere proposed doing a bust of the King. This was a clever means of paying court. They brought him the most beautiful block of marble which could be found. ${ }^{26} \mathrm{He}$ worked straightaway upon the marble, and did not make a clay model as other sculptors are accustomed to do. Instead, he contented himself with making two or three pastel sketches of the King's profile, not, as he said, to copy them in making the bust, but only to refresh his memory from time to

\footnotetext{
24. Daniel Fossier served as Guardian of the Storehouse of Marble and was frequently listed in the Buildings Accounts from 1664 to 1680 .

25. On I8 March 1665 , before Bernini's arrival, Colbert was reported to have had a conversation with the papal nuncio in Paris, Monsignor Roberti, in which he criticized several aspects of Bernini's design, including the smallness of the principal door (Mirot, "Le Bernin en France," p. 187).

26. Perrault himself arranged the delivery of three blocks of marble to Bernini's studio. In a letter to Colbert of 22 June 1665 , he makes the following commentary: "I believe that the principal reason he it for not embarking upon a full-sized statue is the long time that this work demands, and the fact that it would be awkward to engage him in that project in Paris; he speaks of doing it when he returns to Rome, based on the sketch of the bust that he will carry with him. What also makes me believe that he is avoiding that task in this country, is that he excuses himself in part on the grounds that he has not found any marble of considerable size. When I told him that a block could be found that was seven feet high, he said that he needed one that was eight feet high at least, to find some impossibility in the thing, according to my judgment" (G. B. Depping, ed., Correspondance administrative sous le règne de Louis XIV [Paris: Imprimerie Impériale, I855], 4:508).
} 
time. He added that he avoided copying from the pastels, because then the bust would be a mere imitation, which by its nature is always inferior to the original.

\section{PORTRAIT OF BERNINI}

Before saying more about this bust of the King, it is a good idea for me to give you a description of the Cavaliere Bernini. He was slightly below average height, with a pleasing appearance and a bold manner. His advanced age and great reputation gave him even more confidence. He had a lively, sparkling wit and a great talent for making himself shine in company; he was a good speaker, with a full stock of sayings, parables, anecdotes, and witticisms which he used in most of his remarks, not deigning to give a simple answer to a question. He was a very good sculptor, although he made an equestrian statue of the King which was so wretched and so unworthy of its subject that the King had it given a new head in the classical style. ${ }^{27}$ He was a mediocre architect, yet he had a very high opinion of his own talents in that area. He praised and admired almost nothing besides the men and the works of his own country. He very often quoted Michelangelo, and was almost continually heard to say: "Si comme diceva il Michael Angelo Bonarotta." 28

It did not take the King long to notice that Bernini praised few things, ${ }^{29}$ and he said so to the Abbé Butti, ${ }^{3 \circ}$ who was a great admirer of the Cavaliere. This abbot had the effrontery to tell the King that it was Monsieur Le Brun ${ }^{31}$ who was circulating that rumor, because the Cavaliere did not praise Le Brun's work, which was in fact worthless. I have always noticed great hostility towards Monsieur Le Brun on the part of the Italians. Later I will recount several examples of this, and I will say here only that it is a clear sign that they viewed Monsieur Le Brun as one of the greatest painters who have ever lived.

Let us return to the bust of the King. The Cavaliere was happily successful, although there are several flaws. The forehead is too sunken, and takes something

27. This statue, which was remodeled as a statue of Marcus Curtius and given a new head by the sculptor François Girardon in 1687 , was placed on the north side of the Neptune Basin at Versailles. In 1702, it was moved to the southern extremity of the Swiss Lake, where it was not visible from the palace.

28. More correctly in Italian, "Si come diceva il Michel Angelo Buonarotti," or "As Michelangelo used to say."

29. Perrault refers to a rumor that one day when Bernini was displaying the bust to someone, he said: "This is beautiful; but in the original, it's truly ugly." Upon hearing this, the King was very displeased, but merely said of the Cavaliere that "he does not praise many things" (Chantelou, cited in Mirot, "Le Bernin en France," p. 245).

30. The Abbé Butti, who became a naturalized French citizen in 1654 , was named Bishop of Carcassonne.

31. Charles Le Brun (1619-1690), named King's First Painter on 20 July 1664, was lauded by Perrault in "La Peinture" ("Painting"), a poem presented to the Royal Academy of Painting and Sculpture on 4 February 1668. Le Brun was later included among Perrault's Illustrious Men Who Have Lived in Our Century (1697). 
away from the King's handsome countenance. Monsieur Varin ${ }^{32}$ was the first one to have noticed this, or at least to have dared to say it. The nose is a little too pinched, and the sash, which has been so much praised, is not properly understood. Since it wraps around the edge of the King's arm, it can only be a sash which was draped over the bust itself, and not the sash which was on the King's body when the bust was made, because that sash did not cover up his arm in such a way. ${ }^{33}$

\section{ESTIMATE FOR THE LOUVRE CONSTRUCTION MADE BY THE CAVALIERE BERNINI}

While he was working on that bust, all arrangements were being made for the execution of his design for the front of the Louvre. He did an estimate, which was the broadest ever made, and the most full of useless precautions, which however had to be treated as the result of a consummate prudence. He brought from Rome several Murateurs 34 (that is the name given there to those whom we call masons), claiming that we understood nothing about construction.

\section{THE ITALIAN STYLE OF CONSTRUCTION}

He wanted two rules to be observed, which were good practice in Italy, where they use pozzolana3s instead of sand, but which were useless in this country. The first was to use quarry stone in the foundations, without squaring it slightly with a hammer or setting it in a course. Instead, it was to be used just as it was, all irregular, and in no particular arrangement. This was because, as he said, when the stones were thrown in haphazardly, they made a better bond with the mortar, and produced a more solid form. And the second thing was to wet the quarry-stone while it was being used. Our own builders vigorously defended the opposite point of view, so that it was finally decided to have a trial of the two building styles in a courtyard of the Mazarin Palace.

32. Jean Varin or Warin (1604-1672) was the official engraver for coins of currency and for many of the commemorative medallions that were issued in honor of events of Louis XIV's life and reign. No doubt in revenge for Warin's criticism of this bust, Bernini's student Matthia di Rossi (see below, note 49) wrote of Warin's own bust of Louis XIV that "if Monsieur Warin had never worked in marble, it would have been a good try; but had he done it in wax instead of marble, and it had resembled its subject, it would mean little, since Monsieur Warin has been making portraits of His Majesty for more than twenty years, and one might as well have given him a horse to serve as the model" (letter of $\mathbf{I}$ October 1666, Bib. Nat. ms. ital. 2083, p. 59).

33. In I685, some twenty years after its execution, Louis XIV had this bust placed in the Salon of Diana at Versailles.

34. In Italian, muratore (bricklayer).

35. Pozzolana, or pozzuolana, is a type of siliceous volcanic ash used to produce a cement capable of solidifying under water. It is named for the town of Pozzuoli, near Vesuvius. 


\section{TWO TESTS OF WALL AND VAULT, ONE BY THE ITALIANS, THE OTHER BY THE FRENCH}

The murateurs built in their own fashion two walls, between five and six feet in height, on top of which they built a vault of the same construction as the walls; that is, with quarry stones piled up haphazardly. Our builders raised walls of the same height, and placed above them a vault of the same shape and appearance as that of the Italians, with the same materials, but used in the way it is done in France.

\section{THE ITALIAN WALLS COLLAPSE AT THE FIRST FROST, AND THE FRENCH WALLS STAND FIRM AND COMPLETE}

The truth is that when winter descended upon these two structures, the vault of the Italians fell down by itself at the first frost, and the one built by our workers stood firm and even stronger than it had been when it was completed. The murateurs were greatly surprised, and made the excuse that it was the frost which had spoiled everything, as if it were an extraordinary thing for it to freeze in the wintertime. ${ }^{36}$

\section{PARTIAL LISTING OF THE FAULTS OF THE CAVALIERE BERNINI'S DESIGN}

Since the Cavaliere Bernini's design was not very well conceived, and could only be carried out to the shame of France, I made a listing of only a few of the incongruities with which it was ridden, because I thought it inappropriate to point out too many of them the first time. I sent this memorandum to Monsieur Colbert, who was then at Saint-Germain. The first time he came to Paris, after having received my list, he had me step into the garden with him, and even cut short the audience he was granting to someone else, in order to talk to me.

"I was surprised," he said to me, "by the memorandum which you sent me; is everything you indicate true, and have you examined it all carefully?"

"I don't believe, Monsieur, that I wrote anything which was not exactly as I observed it; but I beg your pardon for having taken such liberty."

"You did well," he told me; "continue doing so, because one cannot be too well

36. Chantelou refers to this incident in his diary (Journal du voyage du Cavalier Bernin en France, $\mathrm{p}$. 126). There were also reported disputes among the Italian workers; in a letter from the Abbé Butti to Bernini dated 19 March 1666, the Abbé wrote that it was being declared everywhere "che non possono vivere due italiani insieme, senza mangiarsi il core" (that two Italians could not live together without eating out each other's hearts, i.e., being at each other's throats) (Bib. Nat. ms. ital. 2083, p. 49). 
informed on a matter of this importance. I don't understand," he added, "how this man believes he can give us a design in which so many things are misunderstood." 37

From that moment on, Monsieur Colbert undoubtedly saw that he had approached the wrong party, but he believed he had to follow through on his gamble. Perhaps he thought also that with good advice, he could redirect the Cavaliere to the right way of doing things, and that by showing him his mistakes, he would have him produce something excellent; but he still did not know the Cavaliere.

\section{OPPOSITION BETWEEN THE GENIUS OF BERNINI AND THE GENIUS OF COLBERT}

Furthermore, it would have been difficult to find two kinds of genius that were more opposed. The Cavaliere paid no attention to detail, thinking only about making great theaters or festival halls, and taking no trouble over all the practicalities, all the constraints and all the arrangements of the necessary apartments, things which are innumerable and which demand a kind of commitment that the Cavaliere Bernini did not and could never have, owing to his quick and lively nature.

\section{THE CAVALIERE BERNINI'S TALENTS}

Because, in a word, I am persuaded that as an architect he hardly excelled at all, except with the decor and machinery of the theater. Moreover, it is said that he sometimes went too far with these, such as when he made it seem as though the machines had caught fire. Everyone thought that they would suffocate in the rush to escape from that false conflagration.

Monsieur Colbert, in contrast, wanted precision, and wanted to see where and how the King would be lodged, and how he could be most easily served. He was persuaded, and with reason, that one must manage not only to accommodate the person of the King and all other royalty, but also give convenient lodging to all the household officials, down to the most minor ones, who are no less necessary than the most important ones. He was killing himself to produce and to have others produce memoranda of everything which had to be observed in the construction of all these apartments.

The Cavaliere was extremely bored with all these lists of which he understood

\footnotetext{
37. As published in Jacques-François Blondel's Architecture française (book 6, 1756) and analysed by Mirot, Bernini had conceived of a heavy, sober external façade which echoed "that air of slightly reserated force which still recalled the fortified palaces of the fifteenth century, and had on the contrary reserved all the grace and architectural richness for the courtyards and the ornamentation of the interior" ("Le Bernin en France," p. 239). Most of the rooms were designed as reception halls and were too large for practical lodging, and many depended upon light from windows facing the inner courtyards and had no exterior outlook.
} 
nothing and wished to understand nothing, imagining erroneously that it was beneath the dignity of a great architect like himself to descend to the level of these minutiae. He complained to Monsieur de Chantelou, even doing so in a disrespectful manner. "Monsieur Colbert," he said, "treats me like a little boy" (these are the words of Monsieur de Chantelou's diary, which was shown to me after his death); "with his useless speeches about privies and underground passages, he fills up entire meetings; he wants to be the clever one and understands nothing; he's a real boaster." ${ }^{8} \mathrm{He}$ added that Monsieur Colbert wanted him to commit una mala creanza, 39 and that he had been pushed hard towards that point, but that reason had held him back.

\section{THEY WERE UNHAPPY WITH EACH OTHER}

If the Cavaliere was unhappy with Monsieur Colbert, Monsieur Colbert for his part was no less dissatisfied with the Cavaliere, although he revealed nothing outwardly, and on the contrary, he always spoke of Bernini with remarkable respect. Something happened which opened my eyes to this, and made me see what kind of world is the Court.

\section{OCCASION WHEN MONSIEUR COLBERT LET ME SEE WHAT HE THOUGHT OF THE CAVALIERE BERNINI}

One day Monsieur Colbert said to the Cavaliere Bernini: "We are going to embark upon a building which will cost many millions, but that doesn't matter; the King will have no regrets if it is the way he has every right to expect it to be. I notice, however, that if we don't take care, we will find that in this building, where there are festival halls, theaters, salons of prodigious size, admirable galleries, and everything which creates the majesty of a great palace, the King himself will be obliged to sleep in a room so small that half of the nobles and officials who are entitled to enter will not be able to fit inside. That would assuredly be a serious reproach to us, because it must be established from the very beginning that the Louvre should be regarded as a winter residence; during the other seasons, the King may reside in his other royal houses in the countryside.

"At the same time, the King's apartment must face south, that is, towards the river, where the view is also the most attractive. It should also be established as a constant that one cannot locate the room where His Majesty will sleep in any place

38. In the manuscript, Perrault uses the word cocallon, which is not found in the seventeenthcentury dictionaries consulted for this edition. The 1909 editor of the Memoirs, Paul Bonnefon, evidently considered this indelicate, and wrote it only as " $c-$-," which, however, suggests an even greater vulgarity. In view of Perrault's circumspect suppression of the word bastard later in the text, it is suggested that he did not consider the word cocallon to be particularly rude. A possible interpretation is that it is a derogatory variant of $c o q$ (rooster), indicating arrogance and boastful posturing.

39. "An act of rudeness." 
other than the terminal pavilion of the wing facing the river. By putting the King's apartment on the front face as you have proposed, it would be necessary to set out watchmen to prevent the morning noise of carriages and carts. That particular pavilion, moreover, has only three large windows, of which two will have to be given over to the ceremonial chamber; as a result, there will only be one left for the bedchamber, which will therefore be so small, as I have said, that it will hold only half of those who ought to enter it."

The Cavaliere promised to think about how to remedy this inconvenience. Three days later, he came to the meeting being held at the Louvre concerning buildings, attended by Monsieur Colbert, Monsieur de Chambray, who was the brother of Monsieur de Chantelou, and myself. He brought a design which he held pressed against his stomach, and addressing Monsieur Colbert, he said that he was convinced that the angel which presides over the happiness of France had inspired him, and that he sincerely knew himself to be incapable of discovering on his own a thing so beautiful, so great, and so fortuitous as the idea which had come to his thoughts. "Io sono entrato," he pursued, "in pensiero profondo." $40 \mathrm{He}$ said these words with as much gravity as if he had descended to the depths of hell.

Finally, after a long speech that would have tried the patience of the most selfrestrained of men, he showed his design with the same respect with which one would reveal il vero ritratto di vero crucifixo. ${ }^{41}$ This profound thought was nothing more than a bit of paper glued on to another drawing of the pavilion of the Louvre, on which he had marked four windows in yellow, instead of the three that were in the former design and already in the building. He said that of these four windows, he would keep two for the chamber of public display, and would give the two others to the bedchamber. By moving the dividing wall further back into the large room, he would in fact make that room smaller, but in doing so he would enlarge the bedchamber sufficiently.

Monsieur Colbert seemed to approve strongly of this idea, and gave Bernini much praise. As for me, as I was standing nearby, bursting with indignation at seeing such boasting, I could not prevent myself from whispering to Monsieur Colbert that this could not be done without knocking down the whole pavilion, as well as the three other ones symmetrical to it (something we had agreed never to consider).

The Cavaliere, who was apparently offended by the boldness of my having opened my mouth, since he had not been able to hear, wanted to know what I had said. Monsieur Colbert tried in vain to tell him that it was not worth the trouble of repeating, but the Cavaliere insisted, to the point of saying that he would walk out if he were not told what I had said. Upon his saying that, Monsieur Colbert told him my objection in full. Without responding to my statement, Bernini said proudly that

40. "I entered into deep thought."

4I. "The true image of the true cross." 

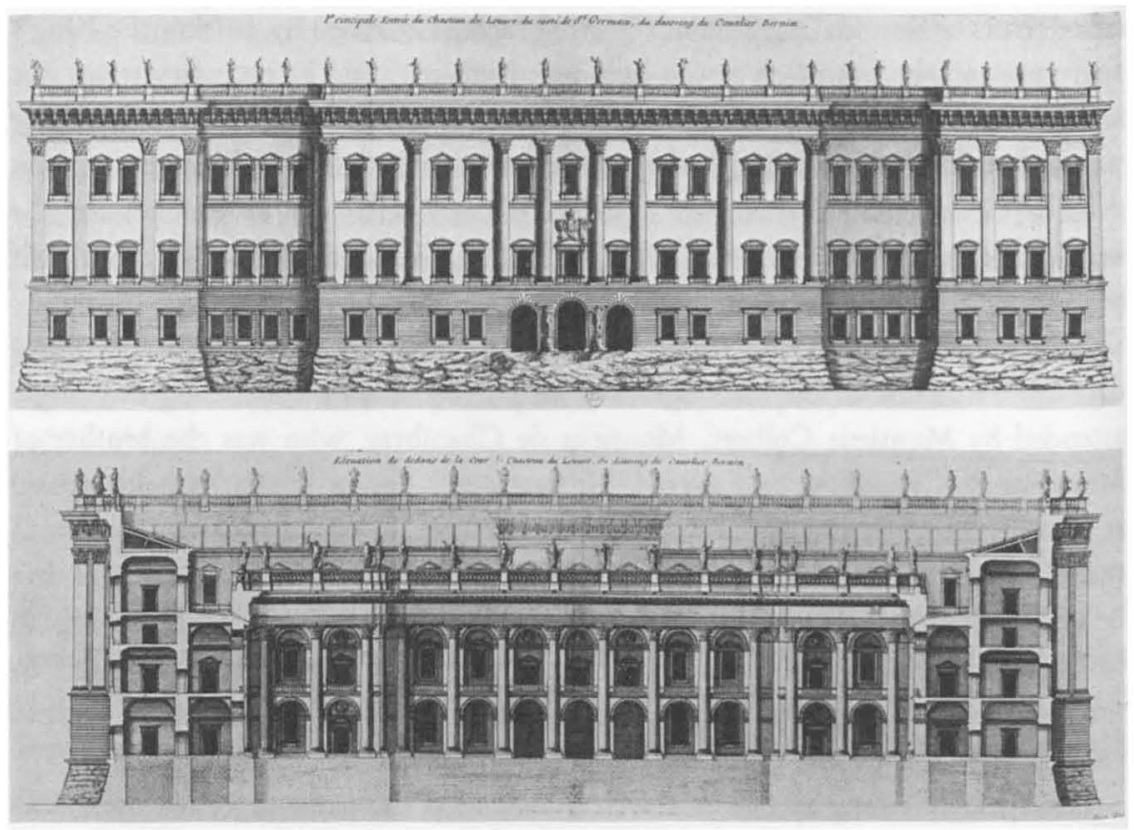

Bernini's design for the Louvre: exterior (modified version) and inner courtyard views of east façade. Courtesy Bibliothèque Nationale.

it was obvious that I was not of the profession, and that I had no business giving my opinion on a matter of which I knew nothing. Monsieur Colbert told him that he was right, and that no attention should be paid to what I said. I was thus treated on both sides as if I were the most wretched and ignorant of men.

The design was admired, and after some other matter was discussed, the meeting adjourned. The Cavaliere went home, and Monsieur Colbert went up to the private room which he had in the Louvre. I followed him, and while passing through a corridor, I begged his pardon for the liberty I had taken by speaking of Monsieur le Cavaliere's design.

"Do you think," he told me angrily, full of indignation, "that I don't see it as well as you do? A plague take that bastard, ${ }^{42}$ who thinks he can pull his tricks on us."

I was astonished, and at the same time I praised God for making me see so clearly what kind of dissimulation one is forced to practice when one is at Court.

After the Cavaliere's designs appeared to have been examined sufficiently, a date was set for laying the first stone in the foundation of the main façade of the Louvre. ${ }^{43}$ The King wished very much to lay it himself, and the ceremony took place in the following manner.

42. In Perrault's original text, the word is written as "b. . .."

43. This ceremony took place on 17 October I665. 


\section{HOW THE KING LAID THE FIRST STONE FOR THE BUILDING BEGUN} ACCORDING TO THE CAVALIERE BERNINI'S DESIGN

The stone which the King laid was approximately one and one-half feet square, neatly cut. On its upper surface, they had carved out a place for the medallion and the inscription plaque, in such a way that the stone which would be placed on top would never touch either object. This upper stone was also carved along its bottom surface, to fit tightly with the stone underneath. The inscription plaque itself was of bronze, one-sixth of an inch thick and five or six inches square. The medallion was of gold, and had on one side the King's head, and on the other the Cavaliere Bernini's design, with these words: Majestati et aeternitati Imperii Gallici sacrum. ${ }^{44}$ It was worth a hundred louis. 45 It was cast by the hand of Monsieur Varin, and with the words of Monsieur Chapelain. The expense of making a die and stamp would have been too great and would have required too much time.

They had prepared a large trough of ebony or blackened pearwood, very fitting to the occasion, a silver trowel, and a hammer of polished iron, with a handle of violet wood, carved also in a very fitting manner.

Monsieur Colbert, with an entourage of buildings officials, stood in the center of the foundation, with the builders and the Sieur Villedo,46 master of the works. Monsieur Colbert held the depth measure, which he then gave me to hold; he gave the trowel, trough, and crowbars to the builders, and the hammer to the master of the works. (Monsieur de Chantelou's diary maintains that the Cavaliere Bernini held the trowel.) The King then came, attended by several nobles of the Court. When His Majesty had arrived, one of the builders gave the trowel to the Superintendent [Colbert], who then presented it to the King. The King took some mortar from the trough and put it on the spot where they were to lay the first stone, which was then placed by the builders upon the mortar. Then the hammer was presented by the Sieur Villedo, and His Majesty struck the stone two or three times.

\section{THE MEDALLION PLACED IN THE FOUNDATIONS}

The medallion and inscription plaque were also presented to His Majesty, who, after having examined them, placed them in the hollow of the stone made for that purpose, upon which the second stone was then laid. After this, His Majesty withdrew, and ordered that 100 pistoles 47 be given to each worker as a bonus.

44. "Holy relic [offering] to the majesty and eternity of the French realm."

45. A louis was formerly worth twenty-four livres; this medallion was therefore valued at the impressive sum of twenty-four hundred livres, compared to Perrault's literary pension that year of fifteen hundred livres.

46. Michel Villedo had served as master of the masonry works of the King's buildings since 1654 .

47. A pistole was a coin worth ten livres; each gift was therefore equivalent to the magnificent sum of one thousand livres. 
Trumpeters, who had been summoned to stand on the rim of the foundation, played fanfares, as they had done upon the arrival of His Majesty. The Superintendent and the buildings officials accompanied His Majesty to the door of the workshed, with the exception of the inspector and the Superintendent's head clerk [Perrault], who remained on the spot, and who did not leave until all was covered over sufficiently, in order to avoid hearing later that the medallion had been stolen during the night.

\section{INSCRIPTIONS PLACED IN THE FOUNDATIONS}

The French inscription, placed in the Louvre's foundations on a large golden plaque, bore these words:

\section{LOUIS XIV, KING OF FRANCE AND NAVARRE}

Having conquered his enemies, granted peace to Europe and comforted his people, resolved to complete the royal palace of the Louvre, begun by François I and continued by successive kings. Work was done at first according to the original plan; but later, having conceived a new design, both larger and more magnificent, and in which earlier construction can only form a small part, he here laid the foundations of this superb edifice, in the year of grace 1665 , the [17th] day of the month of October. Messire Jean- Baptiste Colbert, Minister of State and Treasurer of His Majesty's Accounts, being at this time Superintendent of Buildings.

On another bronze plaque of the same size and thickness, it said:

Ludovicus XIV, Francorum et Navarrae rex christianissimus, florente aetate, consummata virtute, devictis hostibus, sociis defensis, finibus productis, pace sancita, asserta religione, navigatione instaurata,

\section{Regias Aedes}

Superiorum principium aevo inchoatas, et ab ipso juxta prioris exemplaris formam magna ex parte constructas, tandem pro majori tam sua quam imperii dignitate longe ampliores atque editiores excitari jussit; earumque fundamenta posuit anno R. S. M DC LXV. Octob. operi promovendo solerter ac sedulo invigilante Joan-Batista Colbert, Regi. Aedif. Praefecto. ${ }^{48}$

\section{MY QUARREL WITH THE CAVALIERE BERNINI}

One day when I was in the Cavaliere Bernini's studio, where he was retouching the bust of the King, I amused myself by studying the design of the Louvre façade from

48. A free translation of the Latin inscription is as follows: "Louis XIV, Most Christian King of France and Navarre, in the prime of his age and consummate virtue, having conquered his enemies, defended his allies, enlarged his borders, established peace, championed religion, and restored navigation, orders that the Royal Palace, begun in the age of his predecessors, and built by him in a style greatly similar to earlier examples, be at last built very much larger and more imposing, for its greater majesty as well as dignity; the foundations of this were placed in October 1665, the work skillfully and assiduously carried out by the watchful J.-B. Colbert, Superintendent of the King's Buildings." 
the angle of the river, which the Sieur Mathias, 49 the Cavaliere's student, was then drafting. Noticing that one side was not like the other, I asked the Signor Mathias what was the reason. The Cavaliere, who heard me ask this question, became suddenly furious, and said to me the most outrageous things imaginable, including among other things that I wasn't worthy of scraping off the soles of his shoes. After allowing him to vent his spleen, I told him as sincerely and respectfully as I could, that I did not claim to find anything amiss in his design, but that as I had the honor of being the First Clerk of Buildings, I had thought to learn from his student what I did not know, and since I was exposed every day to a thousand questions about the buildings from persons of quality, I had asked the question which had offended him, in order to be able to reply to those who would ask me the same thing. What I told him was so reasonable that his anger diminished a little; however, he continued to repeat these words:

"A man such as I! I, whom the Pope treats graciously, and for whom he has great regard, that I should be treated thus! I will complain to the King, even if it should cost me my life: I want to leave tomorrow and be gone. I don't know why I don't take the hammer to this bust, after being so scorned. I will go to Monsieur the papal nuncio."

I never knew whether he went or not, but he spoke neither to the King nor to Monsieur Colbert, and the matter rested there. Monsieur de Chantelou says in his diary that it was he who prevented Bernini from complaining, saying that it would ruin the career of a young man. ${ }^{\circ}$ However, he could have done me no damage, because when I spoke to Monsieur Colbert on the very same day, recounting the incident exactly as it had happened, he merely said that I would have done better not to say anything about the Cavaliere's design, but that I should have no fear; that Bernini was too clever a man to create an incident under the present circumstances. I do in fact think that if he had already received the three thousand golden louis that I brought him when he departed, as I will describe later, he might well have created some kind of uproar.

49. Matthia di Rossi (1637-I695), Bernini's student, accompanied him on his sojourn in Paris. Rossi later returned to France in May 1666 to supervise the Louvre construction until the plan was abandoned One year later. After Bernini's death, he became the principal architect of St. Peter's Basilica in Rome, and he also designed a celebrated mausoleum for Pope Leo X, who had died in Is2I.

So. Chantelou's diary verifies this incident, but Perrault's reaction is described less favorably:

"Monsieur Perrault, seeing that he took it that way, was quite alarmed. He begged me to mollify the Cavaliere . . " (Journal du voyage du Cavalier Bernin en France, p. 206). Chantelou also reported that Perrault had gotten Matthia di Rossi's servant out of bed at five o'clock the following morning and had brought another man to plead with Bernini on Perrault's behalf. Bernini was persuaded to accept Perrault's apologies and promised to let the matter drop (p. 2II). The notion of "ruining the career of a young man" is somewhat doubtful, since when this incident took place on 6 October I66s Perrault was already thirty-seven years old; Bernini himself, however, was sixty-seven, and Chantelou was fifty-four. 


\section{TWO OF THE CAVALIERE BERNINI'S PROPOSALS FOR THE LOUVRE FOUNDATIONS, WHICH WERE BOTH FOUND TO BE WORTHLESS}

The Cavaliere proposed two things for the construction of the Louvre's foundations, aside from those I have already mentioned, that is, to dampen the quarry stone and to pile it haphazardly. The first was to move the third layer of the foundation two feet back from the rest, which would have been worthless because it would have rested upon the edge of the stones underneath; this recess was eventually reduced by almost half. The other proposal was to excavate the ground vertically, which was also worthless and was not followed.

\section{SAYINGS OF THE CAVALIERE BERNINI}

Monsieur de Chantelou has recorded in his diary many apothegms and witticisms of the Cavaliere Bernini, which I will list here straightaway to avoid the bother of marking the times, places, and encounters where he said them, circumstances which have no useful bearing.

In speaking of the bust of the King that he was going to do, he said that a marble bust was like a face which was completely white, etc.

He said that it was not shameful for France to have taken an architect from Rome, just as it would not be shameful for Rome to send to France for a military general, if there were a need.

He said that having asked Pope Urban VIII for a dowry for his daughter, assuring him that she was very virtuous, the Pope replied: "She has a dowry, if she has virtue."

He used to say that the Spaniards had no taste for the arts, and he was openly contemptuous of them. sr $^{\text {r }}$

He considered the Roman Pasquinus (this is a statue of the soldier who supported Alexander when he was wounded at the siege of Tyr) to be the finest work of antiquity, followed by the Torso, which he said was a Hercules.

He said that Pope Urban VIII had written the following epigram about Bernini's statue of Daphne:

Quisquis amans sequitur fugitivae gaudia formae,

Fronde manus implet, bacchas ceu carpit amaras. s2 $^{2}$

I have translated it thus: "Who seeks a love, enflamed by beauty's call, Shall, having conquered, pluck a fruit of gall." 53

5I. According to Chantelou (p. 23), one of Bernini's anecdotes concerned the Spanish Ambassador, who upon seeing the Cavaliere's statue of the Abduction of Proserpina, said: "It is very pretty, very pretty; for greater beauty it would be better if it had those black eyes that the monks give to certain little dogs that they fashion," a speech at which Bernini could hardly contain his laughter.

52. "Any lover who pursues a joy of fleeting form, when the branch fills his hand, plucks bitter fruits."

53. This is a free translation of Perrault's original rhymed couplet, "Qui suit une beauté dont le feu consume / Ne cueille, en l'attrapant, qu'un fruit plein d'amertume," which more literally means, "Whoever follows a beauty, consumed by the fires of love, only gathers, upon capturing it, a fruit full of bitterness." 
He said that the medallions which had the least pronounced relief were by the greatest masters;

That in Rome there was a shield four or five feet tall which only weighed two pounds, which was nevertheless impervious to a musket ball. It is made of three fish skins, one atop the other.

He said that there are training stables in Italy which have up-and-down slopes, in order to accustom the horses to them.

He used to tell the papal nuncio that it was God who inspired him in making the design of the Louvre;

That Michelangelo only made nine or ten statues in his life, although he lived ninety-two years;

That Hannibal Carache, 54 when pressed to give his opinion of Michelangelo's statues, said that one would have to have seen the bodies of men in the days of Michelangelo;

That he had a great enemy in Paris, which was the high opinion in which he was held: il concetto che trovo di me; ss

That one ought to measure water by means of a clock.

He told Monsieur Colbert, who was praising his design, that it was not he but God who was its author;

That [Pope] Paul III said one day: "When I refused mercy to the criminal, my judgment was here (pointing to his forehead); and when I granted it to his sisters, it was here (putting his hand on his heart)."

He said that one could not fill a small vial at a large fountain, and that a feeble genius could not benefit from another genius which was too great and too abundant. (This too great and abundant genius was himself, and I believe that Monsieur Le Brun was meant as the feeble genius, and that he made this clever remark about the silence he maintained regarding Monsieur Le Brun's works);

That it was necessary for students to learn to draw draperies from bas-reliefs (this is usually what is least good in ancient bas-reliefs, in my opinion);

That there should be no flowers in the borders of tapestries, nor burnished gold on picture frames, because they stand out too much; nor should there be ornaments in niches for statues, because the statues themselves are the ornament;

That Raphael was starting to paint like Titian at the time of his death, that is, to add reflections, as one sees in the portrait of Pope Leo X;

Che le fabriche sono i ritratti del'animo dei principi.s6

That the painter Tudescos7 was a totally different man for metalwork design than Monsieur Le Brun.

"I doubt," he said, "that the King is as yet knowledgeable about the finer things; for that,

54. Annibal Carraccio (I560-I609), a painter who lived in Rome under the patronage of the Farnese

5s. "The notion of me that I find there." The full quote, according to Chantelou's diary (p. 40), Was as follows: "Io ho un gran nemico a Parigi, ma un gran nemico. Il concetto que loro hanno di me"

(I have a great enemy in Paris, a very great enemy: the notion that they have of me).

56. "That buildings are portraits of the souls of princes."

57. Adam Elsheimer (1574-1620), born in Germany, lived in Rome and was known as "Il Tedesco" (the German). His work is considered to have been an influence upon Rembrandt. 
he would have to have seen some piece of real architecture. Now that he has seen sculpture (Bernini meant his own bust), he will be a better judge of that than of architecture."

He said to Monsieur Le Brun that one should always make a person's legs longer, rather than shorter (he was right, and that was Monsieur Le Brun's flaw);

That the Spaniards only appreciate polished sculpture, which they call lindo [pretty].

A king says: "I rob my subjects." The minister says: "I rob the king." The tailor says: "I rob the minister." The soldier says: "I rob them all." The confessor says: "I absolve all four of them." And the devil says: "I take all five of them." This story is from the Abbé Butti.

He said that the Trajan Column was the training school of Raphael and Jules Romain..$^{8}$ Michelangelo said that if the Lombards had been able to draw, no one would pay attention to his work or to anyone else's, but that only in Rome was there a Trajan column.

(All this is bragging nonsense. There are some bas-reliefs at the base of this column which are very beautiful, and almost all sculptors have plaster casts of them which are as good as the originals for shaping one's artistic taste. The rest of the column is worth virtually nothing, and since casts of it have been brought to France, there has not been a single painter or sculptor who has gone to copy it, although it was brought here exclusively for that purpose.)

Monsieur de Chantelou said that the lower figures of the Trajan column were designed with the goal in mind of having the upper ones appear to be the same size as the lower ones, because the lower figures were smaller and would be struck by optic rays at the same angle of aperture; this would make all the figures appear to be the same size, although they were in fact quite different from each other. (The good fellow didn't know what he was talking about. I have had them measured by $M$. Girardon, who brought me the measurements which may be found among my papers: the bas-reliefs at the base of the column are of the same height as those above; there isn't a particless of difference.)

He said that there were stones six cubic fathoms in size in the façade of Nero's palace; this is quite ridiculous, even if he might have meant square fathoms instead of cubic fathoms, and Monsieur de Chantelou adds, concerning the confusion over what machines might have been used to raise these stones, that they had an infinite number of slaves. There's a fine solution!

The nuncio asked whether the Trajan column was named after Troy.

When some were criticizing Italian buildings for their exposed roofing, Monsieur the Marshal du Plessis ${ }^{60}$ gave a good reason, aside from the usual one that warm countries do not need pointed roofs, as cold countries do because of great winds and

58. Giulio Pippi, known as Giulio Romano (1499-1546), an Italian painter and architect who was a student of Raphael.

59. Perrault uses the term ligne, a former measurement of length which represented a twelfth of a pouce (thumb-length), approximately 2.25 millimeters.

6o. François Fortia, Seigneur du Plessis (d. 1694), was a finance official in Poitiers and Orléans. 
snows: which is that Italian tiles are very ugly, and they do not have slate as we do in France.

The Cavaliere Bernini said nothing about Monsieur Le Brun's paintings which he saw at the Church of the Carmelites. ${ }^{6}$

The Abbé Butti said that M. Le Brun was the reason why Monsieur Jabac ${ }^{62}$ did not want to show his drawings, for fear that everyone would see how Monsieur Le Brun had plagiarized from them.

The Cavaliere said that Vigarani ${ }^{6} 3$ had no sense either of perspective or of drawing; that his father had known something about mechanical objects, but that the son knew nothing; and that he had everything done by a valet who was more knowledgeable than he.

\section{GIFT MADE TO THE CAVALIERE OF 3,000 LOUIS IN GOLD, A COMMISSION OF I2,000 LIVRES, ETC.}

I should finish here about the Cavaliere Bernini before moving on to other things. When the foundations were well advanced for the front section of the Louvre, according to the Cavaliere Bernini's designs, he demanded to go home, not being able to resign himself to spending the winter in a climate as cold as our own. The day before his departure, I brought him myself, and to do him greater honor, in my own arms, 3,000 golden louis in three sacks, along with a commission for 12,000 livres as an annual stipend, and another for I,200 livres for his son.

The sole reply which he gave me was that such greetings would be quite pleasant, if they were given often enough, and that as far as the stipend was concerned, he believed that he would be paid for one or two years, and no more. I replied that the King's promises were solid, and that he had no reason to doubt them. I was surprised by such a bizarre reception. He was promised 3,ooo gold louis per year if he wished to stay, 6,000 livres for his son and the same amount for his pupil the Seigneur Mathias, 900 livres for the sieur Jules, ${ }^{64} 600$ livres for the sieur Cosme, ${ }^{65}$ his personal valet,

6r. The Convent of the Carmelites was founded in 1604 , in the former Priory of Notre-Dame-desChamps, in the Faubourg Saint-Jacques. Louise de la Vallière, Louis XIV's mistress, retired to this convent in 1674 (see Part 5, note 22).

62. Everard Jabach (1618-1695), a German banker who had taken French citizenship, was a noted art patron. Encountering financial difficulties, he sold his collection of over 5,000 valuable paintings and

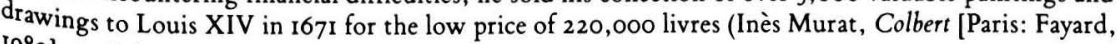
1980], p. 184).

63. Carlo Vigarani (c. 1625-1713), an Italian who became a naturalized French citizen, was in charge of the "machines and pleasures of the King." His father was Gaspare Vigarani (b. 1588), an architect and engineer who was Superintendent of Buildings for the Duke of Modena in Italy.

64. Giulio Cartari, who became Bernini's student at the age of eighteen in 1660 , was the only assistant permitted to collaborate on Bernini's personal works, including the bust of Louis XIV. He is known to have worked with Bernini until 1678 .

65. Cosimo Scarlati, Bernini's steward. 
and 500 livres for each one of his servants; and, in the event that the sieur Mathias should be the only one to stay, he was promised 12,000 livres per year. ${ }^{6} 6$

\section{THE MARSHAL DE GRAMMONT'S JOKE}

The Marshal de Grammont ${ }^{67}$ said that the Cavaliere had demonstrated great generosity on his departure, by giving a coin of thirty sous ${ }^{68}$ to an old woman who had waited upon him during the whole of his stay in Paris. He added that this good woman having thrown the coin back at him, the Cavaliere picked it up. I would not like to claim that the tale was true. He said that he could not tolerate presumptuous people, or pay false homage to their works.

The Cavaliere's servants committed a great misdeed, which I believe was without his participation. The Cavaliere had asked the officers of the wardrobe for one of the King's most beautiful neck-cloths, so that he could copy it on the portrait bust. When the officers asked for its return, the Cavaliere's servants refused to give it back. The King heard talk of this, and did not wish for the issue to be pressed, and so the servants took it away with them.

\section{THE CAVALIERE SHOWS DISSATISFACTION WITH THE PRESENT HE HAD BEEN GIVEN}

The Count du Sault said that the Cavaliere was not happy with the present he had been given. Monsieur Colbert admitted that the Cavaliere had not appeared to be greatly moved by it. Monsieur 69 having said the same thing as the Count du Sault, Monsieur de Chantelou wanted to contradict him, but Monsieur answered back: "The King, however, believes it to be so." And Monsieur the Abbé de Montagu, who had been present when the King had spoken, confirmed what Monsieur had said. Monsieur de Chantelou sent word to the Cavaliere that he should write to Monsieur de Lionne and beg him to be so kind as to set matters right with the King. $\mathrm{He}$ did so; and the King replied that he knew the truth of the matter from an unimpeachable source.

66. According to the Buildings Accounts of 4 June 1666 , Bernini was in fact paid 33,000 livres, while his student "Julio" was given $\mathrm{I}, \mathbf{2 0 0}$, his valet "Cosme" 800 , and an interpreter "Barberet" goo, among other emoluments bestowed on his entourage (Comptes des Bâtiments du Roi, ed. Guiffrey, 1:IO5).

67. Antoine, Duke de Gramont (1604-1678), was a Marshal of France. The following anecdote is verified by Chantelou's diary (p. 258).

68. A sou was worth one-twentieth of a livre.

69. "Monsieur" was the honorary title given to the King's brother, Philippe, Duke d'Orléans (1640-170I). 


\section{THE KING COMES TO THE LOUVRE TO DECIDE UPON CONTINUING THE CONSTRUCTION ACCORDING TO THE CAVALIERE BERNINI'S PLAN}

When it was time to build upon the Cavaliere Bernini's foundations, Monsieur Colbert, who was becoming disenchanted with the plan (to which end my own observations had played no little role), wanted the King, presently at Saint-Germain, to come to Paris in order to see the scale model of the Cavaliere's plans, which had been set up at great trouble and expense. He also wanted the King to declare in the presence of the entire court that the plans should be carried out, so that Monsieur Colbert would be absolved from blame in the public eye, in case the plan should find general disfavor. The day before this resolution was to take place, I put on Monsieur Colbert's desk a memorandum which listed the reasons why the plan should not be carried out. Monsieur Colbert, having read this, summoned me to explain further all the items in my memorandum. He was so much concerned by the problems I had pointed out that he became apprehensive that the King might arrive at the Louvre ahead of him, and announce the resolution to carry out the design in front of the whole court before Monsieur Colbert could get there.

He had his horses put to immediately, and commanded his coachman to drive to the Louvre as quickly as possible. The coachman, who thought that he wanted to go to the Tuileries, which was sometimes called the Louvre when the King was in residence there, took the road to the Tuileries. ${ }^{\circ}$ Monsieur Colbert, having noticed this, leaned nearly his whole body out the window, and shouted angrily: "I want to go to the old Louvre!"; for he was very much afraid of arriving too late. He appeared to be delighted when he learned that the King had not yet arrived.

\section{MONSIEUR COLBERT, TO WHOM I HAD GIVEN A MEMORANDUM LISTING THE AWKWARD ASPECTS OF THE CAVALIERE'S DESIGN, WHISPERS TO THE KING, WHO THEREUPON MAKES NO RESOLUTION}

As soon as His Majesty appeared, Monsieur Colbert stepped forward and spoke to him in a low voice for quite a while. He apparently put forth the principal problems which were involved in following the Cavaliere's design, because after the King rejoined the nobles and courtiers, who had kept themselves at a distance while he spoke to Monsieur Colbert, he asked them what they thought of the Cavaliere's design, of which both the large and small-scale models were before their eyes, but without giving the slightest indication of what he thought himself. This threw them

70. The Tuileries Palace was built by Catherine de Medici in the sixteenth century (begun I564). It was located approximately one-third of a mile west of the Louvre. 
into great confusion, because we know that almost everyone in the King's circle is there only to agree with him, and to rival one another in exaggerating his wisdom. Since they were afraid to disagree with the King's opinion, it was a pleasure to see the cleverness with which they spoke without taking sides for or against it; however, as the Cavaliere had not made himself much liked among them, they leaned more toward criticism than toward praise.

The King did not declare himself, and after a vague and inconclusive conversation which he had with the nobles in his train about the large and small-scale models, he departed without resolving anything, and everyone followed him without saying a single word. I found this silence to be as astonishing as anything I have yet seen.

\section{MEMORANDUM TO MONSIEUR COLBERT SHOWING THAT THE CAVALIERE'S PLANS WOULD INVOLVE TEARING DOWN THE ENTIRE LOUVRE}

Monsieur Colbert was undoubtedly uncomfortable about what he had to do.

However, I had pointed out to him that he had promised nothing to the Cavaliere Bernini except on the condition that he would not tear down what preceding kings had had built, and that that had always been the essential and fundamental requirement; and that to the detriment of this condition, the Cavaliere Bernini was completely tearing down the Louvre in two ways: first, by effectively removing the four middle domes, since they could not remain when his plan was carried out; and second, by covering over the exterior of the four sides of the Louvre, and recasting the entire architecture with which they were adorned. For indeed, to remove the columns, cornices, and all the ornaments of a building is to destroy it, no less than a painting is ruined when one paints another image on the same canvas. This memorandum was very urgent and very decisive. Monsieur Colbert summoned me and asked whether I was sure of everything I had put in the memorandum.

"Monsieur," I told him, "the facts are so much the way I have represented them, that Seigneur Mathias agrees with them."

"That's impossible," he replied; "have him come here, give him your memorandum, and ask him to write his reactions in the margin."

\section{SIGNORE MATHIAS, STUDENT OF THE CAVALIERE BERNINI, AGREES WITH ME}

I had him come to my office, and with a pencil which he had, he indicated agreement with every item in my memorandum. I then brought him to the office of Monsieur Colbert, to whom he presented this same memorandum, with marginal notes in his own hand next to each item. When Monsieur Colbert had read it, he paced up and 
down his office for quite some time without speaking, which frightened me more than all the words I had ever heard him utter. Finally he said this:

"The Cavaliere thinks himself a great man, and has taken us all for great fools; but he is equally mistaken on both points. Monsieur," he continued, speaking to Signore Mathias, "think about going home; I am pleased with you, and I will see to it that you are pleased also. But, monsieur, since you knew very well that he was going to destroy the Louvre, contrary to the conditions under which he was always supposed to work, and under which he came to France, how is it that you did not point out to him that he was not observing them?"

"I pointed it out to him many times," Signore Mathias replied, "but he always answered me by saying that it was not my place to think about it, and that he had brought me only to draw and to carry out his ideas."

\section{SIGNORE MATHIAS RETURNS TO ROME}

Signore Mathias was well paid and departed promptly, without our hearing anything further said about him or about the Cavaliere Bernini, regarding the construction of the Louvre. ${ }^{7 r}$

\section{EQUESTRIAN STATUE OF THE KING DONE BY BERNINI AND SENT TO VERSAILLES}

It is true that the Cavaliere Bernini undertook to do an equestrian statue of the King, which, according to his promises, was to be the most beautiful thing in the world. The statue cost an enormous sum, and when it was delivered to Versailles by means of extraordinary struggles and contrivances, it was found to be so hateful that the King had it removed from the spot where it was placed and had the head taken off, which had been intended to resemble him, and Monsieur Girardon put on a new head modeled in the classical style. No one has ever been able to find out why Bernini had so little success with this work: some said that age had greatly enfeebled him, while others claimed that the chagrin of having his designs rejected had led him to take this revenge. 72

\section{MONSIEUR COLBERT SHOWS THE KING TWO DESIGNS FOR THE FAÇADE OF THE LOUVRE, ONE BY MONSIEUR LE VAU, THE OTHER BY MONSIEUR PERRAULT, THE PHYSICIAN}

Although Monsieur Colbert was very pleased with my brother's design, he did not neglect to have Monsieur Le Vau draw up one himself. Then, he presented both of

7I. Matthia di Rossi left for Rome at the end of May 1667.

72. This statue is described above (see note 27). 
them to the King, so that the one which pleased him the most might be chosen. I was present when these two designs were offered. It was in the King's private chambers, at Saint-Germain; there were only His Majesty, the captain of the guard, Monsieur Colbert, and I. The King examined both designs quite attentively, and then he asked Monsieur Colbert which one he found most beautiful and most worthy of execution. Monsieur Colbert said that, if he were the judge, he would choose the one which had no gallery (as the term peristyle was not yet given to those rows of columns, placed along the length of a building, which form a kind of covered gallery which connects to all the rooms of the apartments). That design was Monsieur Le Vau's, and I was quite taken aback. But no sooner had he declared himself in favor of that design than the King said, "And I choose the other one, which seems to me more beautiful and more majestic." I saw that Monsieur Colbert had acted as a clever courtier, giving his master the full honor of making a choice. Perhaps this might have been a game played between him and the King. In any case, that is the way it happened.

\section{THE KING SELECTS THE DESIGN OF MONSIEUR PERRAULT, THE PHYSICIAN}

Despite Monsieur Colbert's familiarity with my brother's skill in architecture, I noticed that he hesitated to have the design carried out, and that it seemed odd to him that a doctor's ideas about architecture should be preferable to the plans of the most celebrated of all architects. The envy of the Parisian masters of that profession did not fail to be roused by this decision, and spiteful jokes were made, saying that architecture must indeed be ailing, since it was being placed in the hands of the doctors. ${ }^{73}$

\section{ESTABLISHMENT OF A COUNCIL ON BUILDINGS}

I gave a memorandum to Monsieur Colbert in which I proposed the creation of a Council on Buildings, to be made up of Monsieur Le Vau, the King's First Architect, who had nearly thirty years' experience; Monsieur Le Brun, who was a master of all the decorative arts and was not unfamiliar with principles of architecture; and my brother, who had created the design and who certainly possessed considerable talent

73. Among these jokes was undoubtedly the attack by Boileau in Chant IV, verses I-24, of L'Art poétique (1672), in which he portrayed as a "famous assassin" a "bad doctor who became a clever mason." Later, in an epigram of I674 ("A un médecin"), Boileau went even further: "Yes, I said in my verses that a famous assassin, leaving aside the infertile science of Galen, from being an ignorant doctor became a clever mason. But I never intended to speak of you, Lubin; my Muse is too correct for that. You are, I admit, an ignorant doctor, but not a clever architect." 
and skill.74 I added that with Monsieur Colbert at the head of this council, it would be impossible for it not to succeed even beyond his expectations. I had the honor of being the secretary for this council, and I kept a register in which I recorded every resolution that was passed. We met twice a week. This register, which I surrendered with all other documents regarding buildings, is full of very curious things which would be very useful to those who like architecture; because my brother, being nearly always contradicted by Monsieur Le Vau and Monsieur Le Brun, was constantly obliged to prepare dissertations, or rather lessons of architecture, which he would present in writing at the following meeting. I have the original copies, which I treasure. It is true that Monsieur Le Vau and Monsieur Le Brun were incapable of approving my brother's design, saying always that it was only beautiful on paper, and that undoubtedly its execution would be difficult because of the excess depth of the peristyle, which was twelve feet, and that the architraves, 75 which projected into the air, would topple the whole structure; but it was so well supported that nothing in the world is more solid. There is nothing so bold or so beautiful in all the works of antiquity. 76

This Council on Buildings, and the reticence which my brother and I felt about publicizing his authorship of the design which was being carried out, emboldened Sieur Dorbay, 77 a student of Monsieur Le Vau, to say that his own master was its author: a terrible calumny, because it was he himself who had rendered the plan of Monsieur Le Vau which was presented to the King, the same one to which my brother's plan had been preferred. 78

It was not my fault, nor was it my brother's, that Monsieur Le Vau did not have the honor of creating the design that was carried out. I proposed to Sieur Dorbay more than ten times that a peristyle should be placed on the principal façade of the Louvre, and I drew the plan and elevation for him; but he never took a nibble, and did not even speak of it to his master. Because, and I say this in all truth, my brother and I

74. This council was formed in April 1667; by another account, it had already been established in 1665 , and its original third member was François Mansart, not Perrault. Perrault was then presumably appointed after Mansart's death in 1666 (Louis Hautecoeur, Le Louvre et les Tuileries de Louis XIV [Paris/Bruxelles: G. Vanoest, I927], p. I06).

75. An architrave, also known as an epistyle, is the lowest part of the entablature, or solid block on top of a row of columns, that is made up of the architrave, frieze, and cornice.

76. This sentiment not only expresses fraternal loyalty, but also echoes Perrault's position in the Quarrel of the Ancients and Moderns.

77. François d'Orbay (1634-1697), an architect who was the student, collaborator, and son-in-law of Le Vau.

78. D'Orbay's claim was apparently made in late 1693 or early 1694 , as witnessed by a letter from a Swedish diplomat to the architect of the King of Sweden, 21 January 1694: "A certain d'Orbay who designed under the auspices of Monsieur Le Vau has taken it upon himself to dispute the late Monsieur Perrault over the design of the façade of the Louvre, and to attribute it to Monsieur Le Vau and to himself. He claims to be preparing a written proof of this. Monsieur Perrault [Charles] is not saying a word, for the express purpose of allowing [D'Orbay] to be hoist by his own petard" (cited in R. Josephson, "Quelques dessins de Perrault pour le Louvre," Gazette des Beaux-Arts, 1927, 2:188). D'Orbay had the support of Boileau in this matter, but evidently no documentation was ever submitted. 


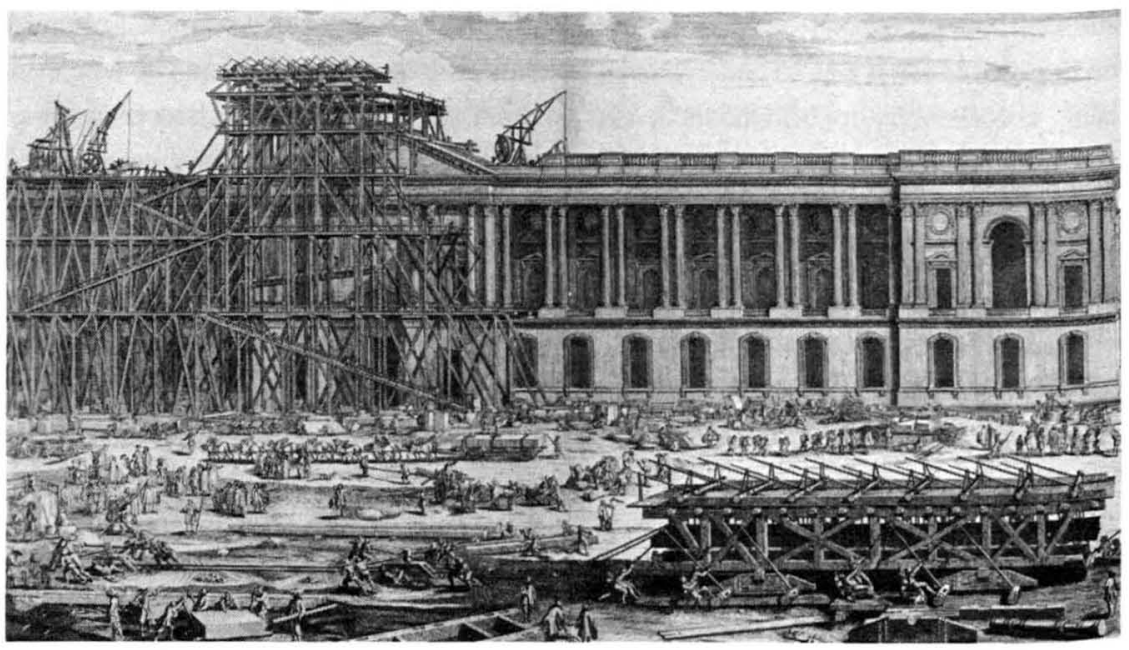

Construction of the Louvre colonnade according to Claude Perrault's design. Courtesy Bibliothèque Nationale.

had such a love of peace and harmony that there was nothing we would not have done to maintain the natural order of affairs, according to which the King's First Architect of Buildings should be the one to design whatever is built for the monarch, especially in a project of this nature.

\section{A SCALE MODEL IS MADE OF THE FAÇADE OF THE LOUVRE, WITH THE SAME NUMBER OF STONES WHICH THE ACTUAL BUILDING SHOULD HAVE}

To alleviate any anxiety which Monsieur Colbert might feel about the construction of this building, I proposed to him that he might see fit to have a small model made of the peristyle, with small hewn stones of the same shape and number as would be used in the full-scale structure. When it was completed, and secured by tiny iron bars of a thickness proportional to the ones which would be used in the actual structure, Monsieur Colbert was firmly convinced of the strength and solidity of the whole building, in which the iron is not a support, but merely counters the thrust of the architraves. This thrust is so strong that no amount of pushing against it could serve to break it, since it acts as a rivet and not as a support. There was also an empty space worked out between the ceiling of the peristyle and the roof above, where several men could go and work unimpeded to repair the problems which might occur over the course of time. The whole thing was so well constructed that nothing has yet failed, and there is every appearance that this building will last forever. The details of its construction are in the first volume of my brother's architectural plans, which is among my books. 


\section{Part 4 \\ ART, PATRONAGE, AND POWER}

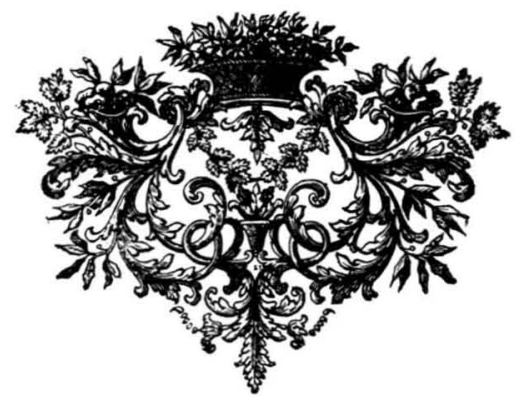

MONSIEUR COLBERT ORDERS ME TO SEEK A PLACE IN THE FRENCH ACADEMY

At about that time, Monsieur Colbert having asked me for news of the French Academy, thinking that I was a member, and my having replied that I knew nothing about it, not having the honor of being a member of that company, he appeared to be surprised, and told me that I ought to be. "It's a group," he added, "which is dear to the King, and since my duties prevent me from attending as often as I would like, I would be pleased to find out through you what is taking place. Ask for the next seat which becomes vacant."

Shortly afterwards, Monsieur Boileau, the brother of Monsieur Despréaux, happened to die. ${ }^{\mathrm{I}}$ All the Academicians to whom I spoke, or whom I had had others approach on my behalf, promised me their votes and told me that I needed the endorsement of Monsieur the Chancellor. ${ }^{2}$ I went to see him at Saint-Germain-enLaye, ${ }^{3}$ where he told me that he had promised the Marquise de Guiche, his daughter, that he would give the place which I was seeking to the Abbé de Montigny, 4 but that he would gladly give me his vote and endorsement for the first seat that became vacant.

A few months later, Monsieur de la Chambre, ${ }^{5}$ a renowned physician and member of the Academy, happened to die. The whole Academy immediately promised me his

I. Gilles Boileau (I63I-I669), a poet, lawyer, and civil servant who had been named Treasurer of the Sainte Chapelle, was five years older than his brother, Perrault's rival Nicolas.

2. Pierre Séguier (I588-1672), a founding member of the French Academy, was a Chancellor of France and became the official Protector of the French Academy upon the death of Richelieu in 1642 .

3. The sixteenth-century palace of Saint-Germain-en-Laye, some twelve miles west of the Louvre,

Was where the infant Louis XIV had been baptized on 5 September 1638 , and it served as one of the royal residences during the construction of the Louvre and Versailles.

4. The poet Jean de Montigny, Bishop of Saint-Pol de Léon, was ironically the same member whose death in 1671 created the vacancy to which Perrault was elected.

5. Marin Cureau de la Chambre (1594-1669), member of the French Academy and the Academy of Sciences (see Part 2, note 27). 
place; but Monsieur Colbert told me not even to consider it, because Monsieur de la Chambre, ${ }^{6}$ also a physician and the son of the deceased, had already solicited the seat for his brother, the curate of Saint-Barthelémy. I therefore put aside the notion, and it was necessary for me to plead forcefully with nearly everyone in the company who had wanted to nominate me, so that they would not do so; and I had to impress upon them how serious it would be if, for my sake, Monsieur Colbert's wishes were not carried out. Monsieur de La Chambre was therefore elected, and I still waited. The Academy's actions in this matter, with which I was quite happy, displeased my brothers so much, and they plagued me so much with the subject, that I allowed Monsieur Régnier, ${ }^{7}$ Monsieur Quinault, ${ }^{8}$ and several others to pass ahead of me. But finally, after the death of the Abbé de Montigny, Bishop of Léon, the Academy nominated me without my having made the slightest appeal.

When the day of my reception arrived, I delivered a speech which the company gave every evidence of finding satisfactory, but in such a spontaneous way that I could not doubt the sincerity of their praise. 9 That led me to tell them that if my speech had pleased them, it would have pleased the whole earth, if it could have heard me; it seemed to me that it would not be inappropriate for the Academy to open its doors to the public on the days when new members were received, and let itself be seen on these kinds of occasions when it is "dressed up," just as it is fitting that the doors be closed when the Academy is working on its dictionary, because the public is incapable of understanding the beauties of this work, which cannot proceed without arguments and even sometimes without anger.

\section{THE ACADEMY RESOLVES TO OPEN ITS FUTURE RECEPTION DAYS TO THE PUBLIC}

Since what I said was so reasonable, and moreover most of them believed that this idea had been suggested to me by Monsieur Colbert, everyone supported it and approved it as with one voice. ${ }^{\text {ro }}$ Only Monsieur Chapelain, a rigid observer of former custom, was opposed for a while, claiming that nothing should be innovated; but he was supported by no one.

6. Marin Cureau de la Chambre's two sons were François, a physician, and Pierre (1640-1693), a priest who had accompanied Bernini on his return to Rome and remained the Cavaliere's faithful admirer for many years. The appointment of one of Bernini's acolytes to the Academy in 1670 was undoubtedly an additional blow to Perrault's pride.

7. François-Séraphin Régnier Desmarais (1632-1713), an abbot, was in fact elected to replace Marin Cureau de la Chambre, whereas Pierre Cureau de la Chambre replaced the author Racan. Perrault's recollection of this specific order of events is understandably vague.

8. Philippe Quinault (see Part I, note 27) was elected to the Academy in I670.

9. The text of Perrault's address, Speech of Thanks to the Gentlemen of the French Academy, upon His Reception on November 23, 1671, is given in Appendix B.

10. Perrault's ironic observation here reveals the frustration of his position, as a writer who was perceived as a mouthpiece for the much-feared Colbert, and who was treated in the Academy either with resentment or, as in this case, with sycophantic deference. 
The first man to be received after me was the Abbé Fléchier, now the Bishop of Nîmes. ${ }^{\text {II }}$ There was a crowd of people, and of people of high society, and the public displayed extreme pleasure at this new arrangement.

One can say that the Academy changed its aspect at that moment; from being little known, it became so famous that one hardly spoke of anything else. This continued ever since, always increasing; after speeches from the new member and the director, which were much more carefully written and polished than when they had been delivered behind closed doors, several members of the company would read from their own works, on all kinds of agreeable subjects. The younger Abbé Tallemant ${ }^{12}$ gave speeches on three or four occasions that were wonderfully eloquent, but above all so well delivered that the entire company was carried away. The satisfaction that he gave the public, and especially Monsieur Colbert, was the cause of his good fortune; Monsieur Colbert had the King give him the Priory of Sausseuse, near Vernon, and a stipend of I, 500 livres, in the hope that he would become an excellent preacher. $\mathrm{He}$ had begun to apply himself to preaching since childhood, and had been very successful; but having tried to return to it after ten years of interruption, he could not recapture the same skill, and abandoned everything.

\section{THE KING WISHES TO BE PROTECTOR OF THE FRENCH ACADEMY, AND ASSUMES THAT ROLE}

At that time, Monsieur the Chancellor, official Protector of the Academy, happened to die. ${ }^{13}$ The King, who is very attached to that group, was not above succeeding him in the position of Protector of the French Academy. He wanted it to hold its future meetings in the Louvre, in the same place where his councillors met when His Majesty was in residence. Monsieur Dumetz, ${ }^{14}$ Guardian of the Crown's Furnishings, was ordered to decorate that chamber, which he did with a seemliness and even a magnificence which showed his love for letters and for those of that profession. Monsieur Colbert, to whom the honor of the company was very dear, further persuaded the King to give the Academy all the duplicate books in his royal library, which formed a very nice little library. ${ }^{15} \mathrm{He}$ also ordered the purchase of all the books belonging to those members of the company who, being dead, had no heirs who might have donated them; this came to seven or eight hundred books. The intent was

II. Esprit Fléchier (1632-1710) was elected in December 1672 and received into the Academy on the same day as the dramatist Jean Racine.

12. Paul Tallemant (1642-I7I2), who had been elected to the Academy in I666, was also a member of the Academy of Inscriptions and Medals. He became a close friend of Perrault and composed a touching eulogy of him, which is found in Appendix E.

13. Pierre Séguier died at Saint-Germain-en-Laye on 28 January 1672.

14. See Part 3, note 22.

Is. According to a 1674 Catalogue of Books Given by the King to the French Academy (Bibliothèque de l'Institut, AA $1682 \mathrm{~A}$ ), there were 660 books donated according to a directive dated 2I August I673, and Perrault himself received them on behalf of the Academy on 24 August. 
for everyone in the company who wrote something to send a copy to this library, which, in time, would have produced a very handsome accumulation of books, doing great honor to the company; but this practice was not observed very closely.

\section{THE ACADEMY BEGINS TO ELECT ITS MEMBERS BY BALLOT}

When I entered the Academy, the election of Academicians was carried out in the following manner. One month after the death of an Academician, one member of the company, after having spoken with several of his friends in the company, would say: "We have lost Monsieur X, et cetera. I believe that we could not do better than to cast our eyes upon Monsieur Y to take his place. You know his merits, et cetera." I said one day, shortly after my reception, that it seemed to me that God had certainly aided the company in the choice of those whom it had received up until then, considering the manner in which they had been nominated; ${ }^{16}$ but that, in my opinion, it would be tempting Him to continue to make use of Him in that way; that my idea was that from then on, we ought to elect by means of polls and ballots, so that each member might be in complete liberty to nominate whomever he pleased. Since it was believed that this idea did not come only from me, but that it could have been inspired by Monsieur Colbert, or at least held his approval, everyone agreed that we ought to take this route in future. This was put into effect and luckily so, because considering the tremendous zeal with which people have later sought to join the company, it would have been filled with a great number of bad choices, and there would have been great arguments at each one of the meetings.

\section{MACHINE TO ELECT OFFICERS}

I donated a little machine for use in these elections and in choosing officers, which is certainly convenient, and I was very pleased to make that expenditure. ${ }^{17}$

Monsieur Colbert, having observed that the assemblies of the Academy were not held with the regularity necessary to advance its work on the dictionary, on which it had been working for more than forty years, ${ }^{18}$ established the order of meetings which I will now describe. There was no stipulated hour at which the assembly ought to begin work, or to finish; some members came early, others quite late; some were just arriving while others were beginning to leave, and sometimes the whole

16. One may read into this comment a thinly veiled sarcasm, since many of those who believed that Perrault was a mere puppet had no doubt themselves been elected because of family connections or political pressures.

17. As cited in Bonnefon's edition of Mémoires de ma vie, p. 95, Perrault made his proposal at the session of 21 November 1672 , actually one year after his reception, and it was approved by eighteen out of the nineteen members present. The exact nature of this machine is not known, but it appears to have been a device for tallying votes, perhaps similar to an abacus.

18. The Academy had presumably been working on the dictionary since its foundation in 1635 . 
meeting was spent in idle conversation. It was resolved that the meeting would begin at the stroke of three o'clock, and that it would finish at the strike of five o'clock.

\section{CLOCK, RECORD BOOKS, LIGHT, ETC., GIVEN TO THE ACADEMY}

In order to carry out this policy with precision, Monsieur Colbert had a pendulum clock set up and given to the Academy, with an order to Sieur Thuret, a clockmaker, to run and maintain it. Monsieur Colbert also had us given a record book, covered with Moroccan leather and very fine, in which the secretary wrote down all the company's deliberations; he gave us desks, torches, wax, and firewood, and arranged a salary for one of the Louvre's garrisoned soldiers to open up, close up, and clean the rooms where the company assembled, and to serve as a sort of bailiff and caretaker.

\section{TOKENS GIVEN TO THE ACADEMY}

In order to offer even greater encouragement to the Academicians to be faithful in their attendance, Monsieur Colbert established that they would be given forty tokens on each day when they met, so that there might be one for each person in the event that everyone was there (which has never happened), or rather to be shared among those who were present, and that, if it happened that some tokens were left over and could not be shared, they would be added to the distribution at the next meeting. ${ }^{19}$

$\mathrm{He}$ had thought to give a half-louis in gold to each of the members present; but he realized that this generosity could ruin the Academy, because that kind of distribution would run to eight or nine hundred livres a year, which would be regarded as an excellent benefit, and which the nobles of the Court would solicit for themselves as well, to be given to their chaplains, their children's tutors, and even their valets, as reward for their services. This reflection made him hesitate even over the tokens; but, having considered that the cost would be quite moderate, ${ }^{20}$ and that it would be a marvelous stimulus for inspiring or at least inducing the Academicians to attend the meetings, he made up his mind to give this reward to the company. We owe to him in part the completion of the dictionary, for, after this practice was established, we worked ten times better and faster than we had done up until that time.

In order to prevent the tokens from being given to those who arrived after the hour was struck, something which had begun to happen out of a kind of consideration for those members, and would have canceled out any benefits which the tokens were expected to produce, I myself purposely entered just a moment after the hour

19. In a note written in the margin of the manuscript, Perrault adds: "These tokens [have] on one side the head of the King with these words: Louis the Great, and on the other side a crown of laurel with these words: To Immortality, and around [the edge]: Protector of the French Academy."

20. The value of the jeton was 32 sous, or 1.6 livre; for forty members, attending sessions twice a week, the maximum possible cost per year would only be 6,656 livres. 
had struck, on two or three occasions. They wanted to put me on the list for participating in the distribution of tokens; I refused, so that once it was established that I was not excused when I arrived after the hour, no one could complain if they were treated in the same way.

\section{THE KING CONSENTS TO HAVE THE ACADEMY ADDRESS HIM, ON ALL OCCASIONS WHEN THE PARLIAMENT AND OTHER SOVEREIGN COURTS ARE SUMMONED TO ADDRESS HIM}

Another thing also happened at that time which cast the Academy into prominence: that is, the King saw fit that the Academy should come and address him, as well as the Parliament and the other superior courts, on all occasions when he saw fit for the others to be accorded this honor. It is to Monsieur Rose, ${ }^{21}$ Secretary of the Cabinet, and who later joined the Academy, that we are obliged for this. This is how the thing happened.

The King was playing tennis at Versailles, and after having finished his match, he was being rubbed down while surrounded by his officers and courtiers, when Monsieur Rose, who saw that he was in good spirits and in a mood for hearing jokes, said these words to him: "Sire, one cannot disagree that Your Majesty is a very great prince, very good, very powerful, and very wise, and that everything is very well ruled in the whole kingdom; however, I see a horrible disorder reigning there, which I cannot prevent myself from warning Your Majesty about."

"And what," said the King, "is this horrible disorder, Rose?"

"It is, Sire," replied Monsieur Rose, "that I see councillors, presiding chairmen, and other people in long robes, whose true profession is not to give speeches, but rather to dispense justice to one and all, yet they come to make you speeches about your conquests, while those who make a particular profession out of eloquence are left in peace. Doesn't good sense demand that each one carry out his own profession, and that the gentlemen of the French Academy, who because of their training are given the duty of cultivating the precious gift of speech, should come to fulfill their obligations to you on those days of ceremony on which Your Majesty wishes to hear the applause and the songs of joy from your people, on the fortunate success which it pleases God to give your armies?"

"I believe, Rose," said the King, "that you are right: we must bring such a great disorder to an end, and in future, let the French Academy come to deliver speeches to me, like the Parliament and the other superior companies. Inform the Academy of this, and I will command that it be received as it deserves."

21. Toussaint Rose (16II-I70I) had been in the service of both Cardinals Richelieu and Mazarin, and as Secretary of the King's Chamber and Cabinet, he had the authority to write and sign on the King's behalf any letters that were deemed unworthy of the sovereign's time. This episode took place in I668, although Rose himself was not elected to the Academy until I675. 
Monsieur ${ }^{\star \star \star},{ }^{22}$ who was then the director, followed by the entire Academy in a body, went to address the King at Saint-Germain, following the Parliament, the comptroller, and the Court of Assistance. The Academy was received in the same manner as these other companies. The grand master of ceremonies went to summon us in the hall of ambassadors, where everyone had assembled, and led us to the King's chamber, where the Secretary of State of the King's Household was present, and introduced us to the King, who was expecting us. The speech was extremely well received, and the King gave evidence of great pleasure in having called the Academy to this ceremony. It has continued ever since to discharge this duty at every occasion which has presented itself, receiving the highest praise.

\section{THE ARCH OF TRIUMPH}

After the conquests of Flanders and Franche-Compté, ${ }^{23}$ Monsieur Colbert proposed the raising of an Arch of Triumph to the glory of the King. Monsieur Le Brun and Monsieur Le Vau drew up designs for this, and as I had also made one which I sent to Monsieur Colbert, and which I called a mere sketch, he wrote in the margin of my letter that that sketch had pleased him more than the designs that he had been given. It was upon this sketch that my brother based the design which has been executed to scale, as may be seen at the Porte Saint-Antoine. ${ }^{24} \mathrm{He}$ made several other designs, of which some were certainly more beautiful than the one that was executed, but which Monsieur Colbert did not dare choose, because, as he said, they were not in the form that has always been given to these kinds of structures; but in my opinion that was a reason to have preferred them, as they were moreover very pleasing. One can see them in the second volume of my brother's architectural designs. It was Monsieur Gittard, ${ }^{25}$ an architect, whom Monsieur Colbert charged with carrying out the model, under the supervision of my brother.

When the King went to see this model, he appeared to be completely satisfied; but almost everyone else felt that the arcades, and especially the one in the middle, were not wide enough for its height. Monsieur, the King's only brother, who enjoys telling him all the gossip in the city, told him that everyone was complaining about that fault. The King therefore ordered Monsieur Colbert to make him two small designs, one of the model as it was, and the other with the proportions that were hoped for. My brother made these two designs, which were kept for two or three

22. The asterisks are in the original manuscript, suggesting a memory lapse. The title of Director of the Academy rotated frequently, as it entailed a number of minor administrative duties.

23. These victories took place in 1668 , during the War of Devolution against Spain.

24. This arch of triumph was constructed partly in stone and partly in plaster, and due to expense or lack of interest was never completed. It was located at the former Porte Saint-Antoine, adjacent to the Bastille, and was demolished in 1716 after the King's death.

25. Daniel Gittard (1625-1686), also known for his work on the churches of Saint-Sulpice (in the present-day 6th Arrondissement of Paris) and Saint-Jacques-du-Haut-Pas (sth Arrondissement). 


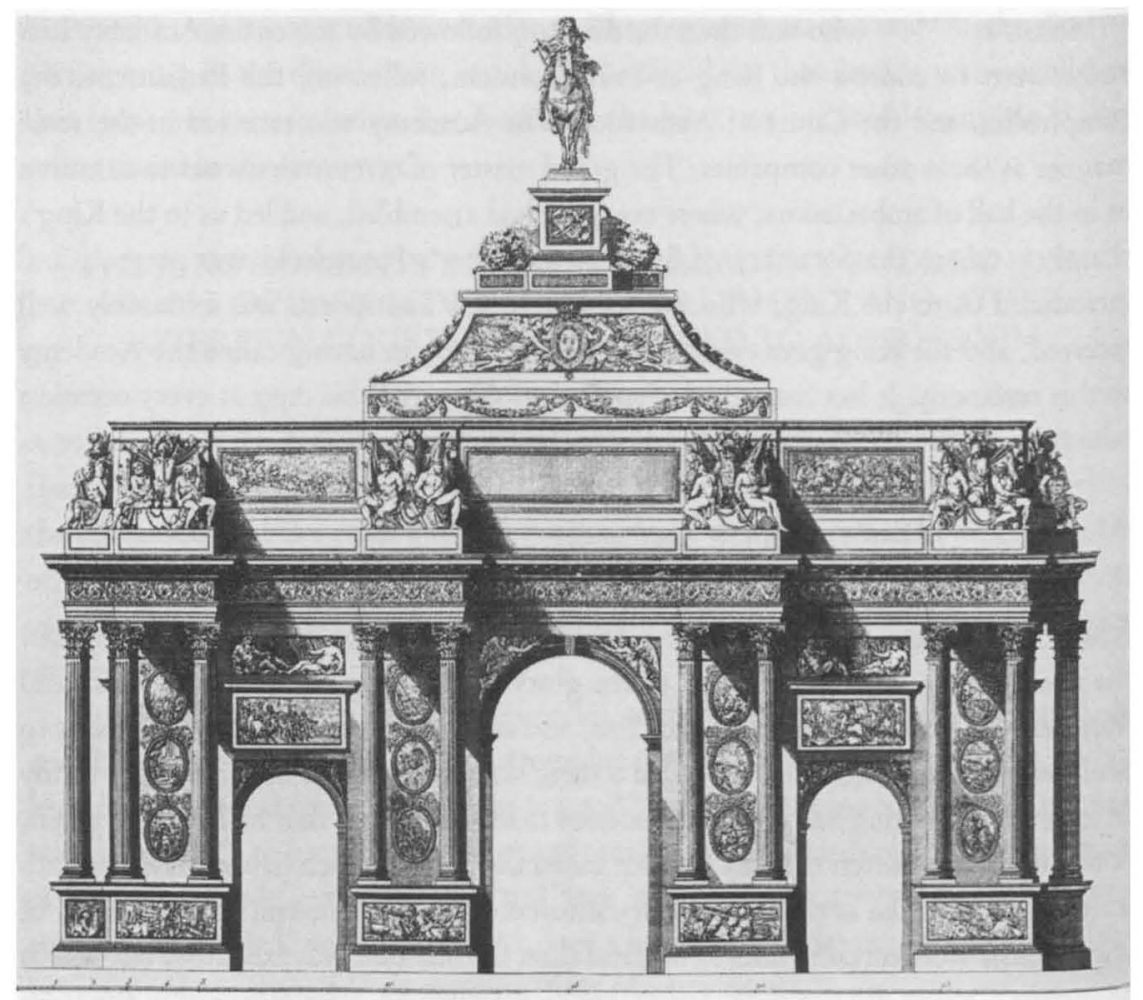

The Arch of Triumph of the Porte Saint-Antoine, designed by Claude Perrault. From J.-F. Blondel, Architecture Française, book 4, I752.

months in the King's chamber, and which His Majesty eventually returned to Monsieur Colbert, saying:

"I still persist in thinking that the design of the model just as it is is more beautiful than the other; however, since one must consider the public, I am inclined to divide the difference in half, and to increase the width of the arcades by half the amount they request."

This resolution was carried out in the actual work, of which the proportions are halfway between those of the two designs. I have these two designs in gilded frames, which I keep as two items of curiosity.

\section{PLAN TO DIVERT THE ÉTAMPES RIVER TO PARIS}

Around that time, a man presented himself who offered to bring the Étampes River, ${ }^{26}$ or at least a part of it, up to the high ground of Paris, in return for a certain

26. Étampes is a city directly south of Paris, in the modern department of Essonne. 
sum of money he was asking. The thing is quite feasible, and he had a map engraved, which is in my print collection, where the course that he would have had the river take is indicated. At the place where the Orge River passes between Viry and Savigny, ${ }^{27}$ he planned an aqueduct that would carry water from one hillside to another, crossing above the river.

\section{IDEA FOR A ROYAL HOUSE}

This led to the birth of an idea of mine, that one could build in that spot the most beautiful royal residence imaginable, because of its fortunate placement and the confluence of waters that met there, namely: the Orge River, which passes through one of the most beautiful plains in the world; and the Étampes River, which would eventually cross and pass over it by means of aqueducts, which, due to their considerable width, would form a canal whose waters would produce prodigious effects in the canal formed by the Orge River, fifteen or sixteen hundred fathoms long and a hundred fathoms wide. ${ }^{28}$ The two slopes on the banks, on the Viry side and on the Savigny side, where there is an infinite number of small streams, would be embellished with an infinite number of fountains. The château would be set upon the brow of the Savigny slope, in the spot where the sun rises, and would command a view of the Seine River as far as and even beyond Corbeil. ${ }^{29}$ It would have on one side the forest of Seguigny, and on the other that of Senart, which would be united one with another by a bridge across the Seine. If I had had the time to make a plan of everything I had imagined, since at that time plans were being set in motion to leave Versailles and to build in a more favorable location, perhaps this spot might have been chosen. The idea of making the Étampes River flow along the slope would only have embellished Paris in this way. The proposal was not listened to. However, the thing is very feasible and would be of very great beauty and even greater usefulness.

\section{PLAN TO BRING PART OF THE LOIRE RIVER TO VERSAILLES}

They listened more favorably to the proposal made to bring a portion of the Loire River to Versailles. Monsieur Riquet, who built the canal connecting the two rivers, ${ }^{30}$ was the one who undertook this task, and had to carry it out in exchange for

27. Viry-Châtillon, which was also the location of Perrault's family home (see Part I, note 3I), is on the east bank of the Orge, and the town of Savigny-sur-Orge is opposite on the west.

28. In a marginal note in the manuscript, Perrault adds: "In the year I70I, I drew this royal house with all the gardens, rivers, fountains, and nearby forests, in three small pictures that $I$ have in my office."

29. The town of Corbeil-Essonnes is located approximately ten kilometers southeast of Viry.

30. Pierre-Paul Riquet, Seigneur de Bonrepos (1604-1680), began the so-called Canal of the Two Seas, known also as the Canal du Midi or the Canal du Languedoc, which connected the Garonne River to the Mediterranean Sea, in I667. It was completed by his two sons, after his death. 
the sum of $2,400,000$ livres. The agreement was ready to be signed, whereupon my having chanced to mention this proposal to the Abbé Picard of the Academy of Sciences, ${ }^{31}$ he told me that it was impossible. He had surveyed the terrain, very casually in all truth, but sufficiently well to be able to assure me that there was no incline on which the river could be brought to the proposed spot, which was on Satori Mountain, 32 facing Versailles. I told this to Monsieur Colbert, who indicated chagrin at what I was telling him; he ordered me, however, to summon Monsieur Picard, who told him the same things with positive certainty. Monsieur Colbert, who was angered by seeing an obstacle to the pleasure he hoped to give the King, pushed the Abbé Picard a bit by telling him that he ought to be careful of what he was suggesting, that Monsieur Riquet was not an ordinary man, and that the great things he had done with the canal joining the two seas were prejudicial in his favor, that he could not be so greatly in error as one would have Monsieur Colbert believe. Monsieur Picard, without saying a single word in reply to Monsieur Colbert, made a bow and withdrew. This action surprised me a little, and Monsieur Colbert seemed not to have expected it.

This conversation took place inside his library. As he was going back to his office, I said to him that if he so desired, I would put Monsieur Riquet and Monsieur Picard together head to head, without either one knowing that it was on purpose, and that I would relate to him as exactly as I could the conversation that they would have together; that I would ask Monsieur Riquet to please tell me about his plan, and with the unexpected arrival of Monsieur Picard, for whom I would have sent, I would easily make them enter into an argument which might shed light on quite a few things. Monsieur Colbert approved my idea, and the next morning, I sent word to both of them to come and see me.

When Monsieur Riquet arrived, since I had sent for him first, I said to him: "Monsieur Colbert ordered me, Monsieur, to gain an understanding of the fine project which you are going to begin for bringing here a part of the Loire River, because he wants me to keep him informed and to enter into the details of the business, so that I can arrange the payments with you. I confess to you, Monsieur," I continued further, "that the thing seems to me to be quite difficult, because Versailles is on a rise, and the Loire River is clearly in the lowest plain through which it flows."

"That is true, Monsieur," he replied; "but the surveyor's level is more accurate than any of the arguments which one can make at a glance and on the basis of mere appearances. I have had levels taken from the Loire, at the point where I want to divert it, to the place where I am supposed to bring it, and I am sure of my business. I have more than enough incline for my needs."

32. Satory was a plateau situated southwest of Versailles. 
"I have been told," I continued, "that you promised, Monsieur, to bring the waters of the Loire to the top of Satori Mountain."

"I don't know what tales they are telling about Saint Satori Mountain."

"There is no saint on that mountain," I told him; "it is called simply Satori Mountain, and apparently you have let it be hoped that you would bring to that spot the water which you promised; because two days ago, Monsieur Le Nôtre33 told the King, while accompanying him on a walk along the canal at Versailles, that it would be a pretty thing to see the ships on the Loire River, with their masts and sails, descend the length of the mountain like sledges, and end up floating on the canal. Monsieur Le Nôtre could not have said that if the King had not told him that you would bring the waters of the Loire to Satori Mountain. The King could not have said it if Monsieur Colbert had not said it to him, nor could Monsieur Colbert, if he had not learned it from your own mouth."

My deduction was a little hasty, but Monsieur Riquet was not bothered by such a trifle.

"Suffice it to say," he said, "that as a gentleman I will accomplish all that I have promised."

At that moment, Monsieur the Abbé Picard entered my office. "Monsieur," I said to him, "you love beautiful things and especially those with a touch of the marvelous. We are going to do at Versailles something which we never believed could be done. Monsieur Riquet is committing himself to bring a part of the Loire River to the top of Satori Mountain: you may judge what water works we will be able to create, having a river in that spot!"

"We don't need any more pumps or mills," replied the Abbé Picard; "but I find the thing very difficult, and Monsieur will please forgive me if I doubt that the waters of the Loire can rise to the height of the ground floor of the château at Versailles, much less be raised to the mountain. Everyone knows that the Seine, at Saint-Germain-en-Laye, is eighty feet lower in summer than the ground floor at Versailles. Well, to believe that the Loire, no matter where it might be tapped, could be higher than the Seine by eighty feet, isn't easy to imagine."

"Imagination," said Monsieur Riquet, "must give way to the just measurements which have been taken."

"Those measurements," replied the Abbé Picard, "are not easy to take, and I doubt that ordinary levels are sufficiently accurate for distances as great as these." They said to each other several more things, in the course of which I saw that Monsieur Riquet was not very sure of his business.

I made a faithful report of this conversation to Monsieur Colbert, who, a few days later, appointed the Abbé Picard and several others from the Academy of Sciences to

33. André Le Nôtre (1613-1700) was the designer of the gardens at Vaux-le-Vicomte and Versailles, and his style of geometric layouts, vast perspectives, fountains, and statues defined the classical French garden of the seventeenth century. 
go and survey all over again the degree of incline from the Loire River to Versailles. They were given orders from the King to go into every place where they might need to take measurements, with a permit from the military guard to let them carry this out in case they might encounter some resistance.

The survey was made with the greatest possible exactness, and with levels of an infinitely greater precision than those of Monsieur Riquet's people, who were for the most part village masons, and it was found that the water could not come further than below the base of the château of Versailles, and that therefore it would not create the effects for which it had been desired. This precaution saved the King not only

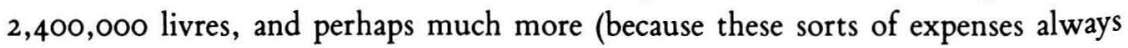
exceed by far the plans that are drawn up), but also the trouble, worry, and damage which would have been done in all the countryside where they would have passed and even where they would not have passed, by making the owners pay dearly for their lands to be spared, without counting the shame of having brought down so many forests, villages, and houses, to no purpose and out of not knowing what one was doing. It was a pleasure to me to have helped to thwart this mad and unfortunate enterprise.

\section{PROPOSAL TO BRING A PART OF THE GOBELINS RIVER TO VERSAILLES}

During this time, or thereabouts, some engineers proposed to raise the Gobelins River at Buc, below Bièvre, ${ }^{34}$ in order to divert part of it to Versailles. Solid citizens of Paris, who were quite ignorant in matters of water elevation and everything associated with it, were the guarantors and associates of these engineers. I felt sorry for them, because I saw that they were going to ruin themselves in an enterprise that could not succeed. I believe that Monsieur Colbert saw this as well and even better than I; but everything which could result in bringing water to Versailles was so sacred and so favorably received by the King, that Monsieur Colbert listened to everything with an inconceivable kindliness, and took unbelievable trouble to verify everything that was proposed, despite being convinced most often that they were only flights of fancy.

\section{PROPOSAL TO MINE METALS IN FRANCE}

About that time, Monsieur Colbert ordered a search for metals in several places in France, on the advice he had been given that there were minerals in abundance, of all

34. The Gobelins manufactory of fine furnishings was established on the southeast outskirts of Paris, now the I3th Arrondissement. It was supplied by the small Bièvre River, which flowed outside the city wall; Buc is a small town in the present-day department of Yvelines southwest of Paris, where the Bièvre originates near Versailles. 
types: because ministers never lack for people who give them advice in keeping with their own inclinations, and Monsieur Colbert would have been quite pleased for all these things to have been found in France. He sent to me all the samples of what was mined, to have them tested in the furnaces of the Academy of Sciences. After spending more than fifty thousand écus, it was found that the cost of mining far exceeded the product, and that it was much more expedient to purchase lead and tin from England, and copper from Sweden, for they had mined scarcely anything other than these three metals, instead of wanting to extract them in France. On this subject he said to me: "We have committed a folly here which is all the more inexcusable for having been committed sixty years ago, or thereabouts, under Henry IV, as we see by the gold and silver coins that we have, where it is written: Ex auro Gallico, ex argento Gallico."3s I told him that sixty years hence, and perhaps even sooner, someone would make the same mistake unless it were written down in several books that this enterprise turned out badly.

\section{GAVE THE DESIGN FOR THE GROTTO OF VERSAILLES, WHICH IS OF MY OWN INVENTION}

When the King ordered the construction of the grotto of Versailles, ${ }^{36}$ I reflected upon the fact that His Majesty had taken the sun as his device, with a terrestrial globe underneath and the words Nec pluribus impar, 37 and that most of the ornaments at Versailles had been taken from the fable of the Sun and Apollo (because his birth and that of Diana, with their mother Latona, had been put into one of the fountains of Versailles, where it still is today), ${ }^{38}$ and that a rising sun had also been put in the reflecting pool which is at the very end of the little park. I thought, therefore, that at the other end of the same park where this grotto was (for it has since been demolished), 39 it would be good to put Apollo about to lie down in Thetis's home after having made a tour of the world, in order to represent the King coming to rest

35. In Latin, "[Made] out of French gold, out of French silver."

36. A rock grotto was built in $1665-1666$ on the site of what would later be the chapel in the north wing of the château. According to contemporary illustrations, the "grotto" was actually a small square building, of which the interior and exterior were decorated with seashell motifs and statuary. It was dedicated to Tethis, who in Greek mythology was the wife of Oceanus and the goddess of the sea into which the sun (Apollo) sinks each night. Perrault, like many of his contemporaries, confused Tethis with Thetis, a Nereid or sea nymph who was the mother of Achilles.

37. "Not unequal to many," a confusing device attributed to the engraver and artist Douvrier, and which the King himself disliked, although as he stated in his own memoirs, "It having already been used in my buildings, and in an infinite number of other things, I have not seen fit to change it" (Lettres, instructions, et mémoires de Colbert, 5:585).

38. A statue attributed to Gaspard and Balthazard Marsy was placed in the Latona Basin in I670, depicting the goddess Latona with her two children Diana and Apollo, imploring Jupiter to punish the citizens of Lycia, who had mocked her. Jupiter thereupon turned the Lycians into frogs, and the statue was modified in 1689 to include more than fifty jets of water and the gilded lead figures of small frogs, tortoises, and men and women with frogs' heads.

39. The grotto was destroyed in 1684 to make way for the new north wing. 


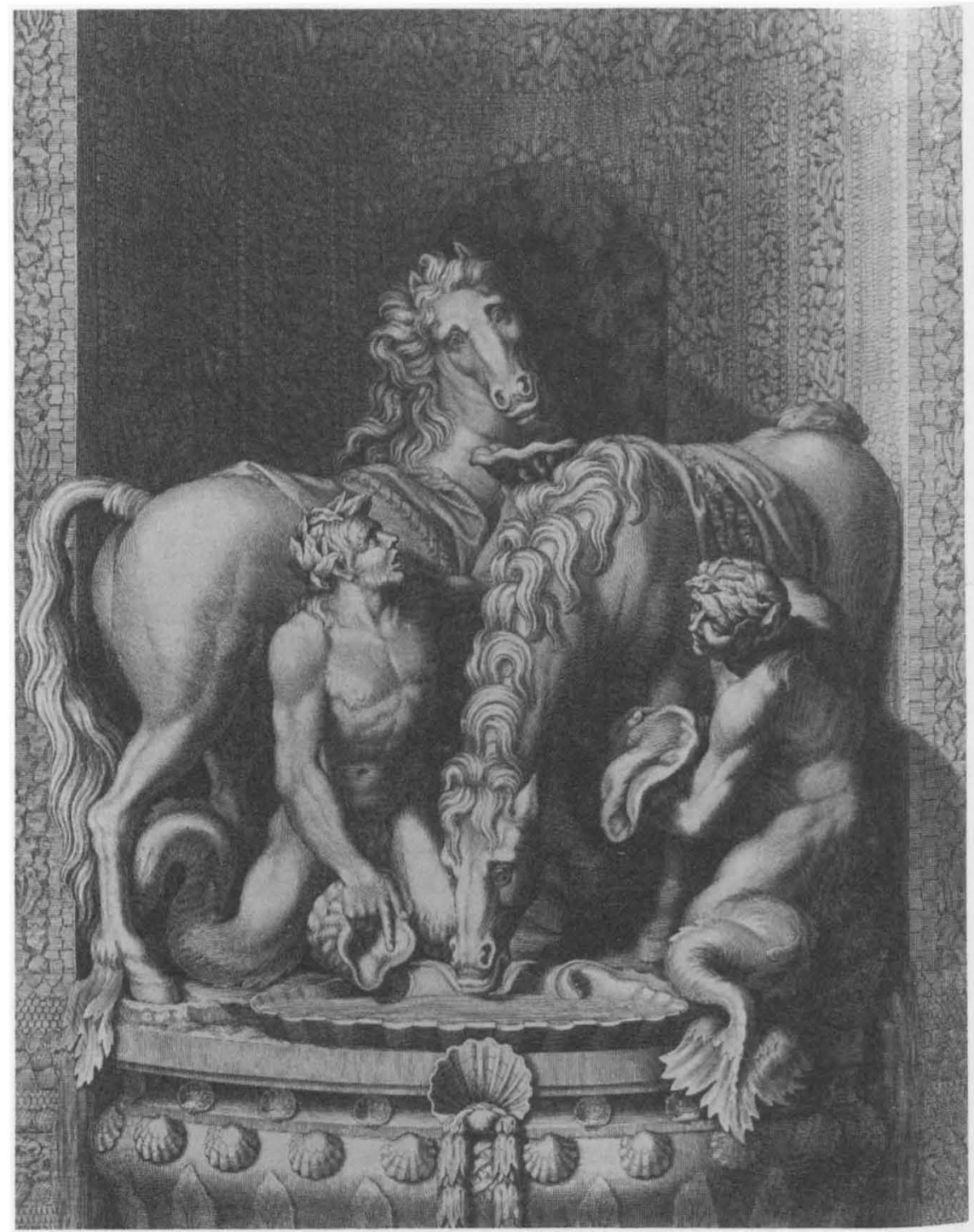

Statuary niche in the Grotto of Thetis (Tethis) at Versailles, attributed to Gilles Guerin. Engraving by Baudet, 1676 . Courtesy Bibliothèque Nationale.

at Versailles after having labored for the good of the whole world. I told my thought to my brother the physician, who made a design of it which was carried out exactly, to wit: Apollo in the large central niche, where Thetis's nymphs are washing and bathing him, and in the two side niches, the four horses of the Sun, two in each niche, being groomed by Tritons. Monsieur Le Brun, when the King had approved this design, drew it to scale and gave it to be carried out, almost without changing a 
thing, to the Sieurs Girardon and Regnaudin for the middle group of figures, and to Gaspard Marsi and Guérin for the side groups, where there were horses groomed by Tritons. $4^{\circ}$ My brother also made designs for all the other ornaments of this grotto, statues, rocks, pathways, etc.; he also made the design for the door, which was very beautiful: it was a golden Sun which spread its rays, also of gold, over the whole breadth of the three doors, which were of iron bars painted in green. ${ }^{41}$ It seemed as though the Sun were in that grotto and that one could see it through the bars of the door.

\section{DESIGN OF THE WATER PATHWAY AT VERSAILLES}

My brother also designed the water pathway, ${ }^{42}$ which was carried out exactly. At that time, the King allowed Monsieur Colbert to be in command of everything, and Monsieur Colbert entrusted us with the invention of most of the designs which had to be made. But, as the ladies of the court had noticed that the King took great pleasure there, they wanted to take a hand in giving their own designs, to provide an agreeable amusement for the King. Madame de Montespan created the design of the fountain of the marsh, where a tree of bronze spouts water from all of its white iron leaves, and reeds of the same substance spout water as well from all sides.

\section{DESIGN OF MARBLE AND BRONZE VASES FOR VERSAILLES}

My brother was ordered to make plans for large marble and bronze vases, to be put in the gardens at Versailles. He made a great number of them, which are in the first or the second volume of his architectural drawings. They were almost all carried out. Monsieur Girardon executed two, among others, which were very beautiful and imposing; they are of white marble, one representing Strength, and the other Gentleness. The handles of the one of Strength are ornamented with lionskins, of which the head and the tail form the handles; four of the major Labors of Hercules are represented on the four sides. For the one of Gentleness, crowns of flowers held by cherubs form the handles. The three Graces and three other subjects ornament the four sides of this vase.

He also made the design of the bas-relief which is below the fountain of the

40. Girardon, who had remodeled Bernini's equestrian statue of the King (see Part 3, note 27), collaborated with Thomas Regnaudin (1627-1706), Gaspard Marsy (1624-1681), and Gilles Guérin (1606-1678). After the destruction of the grotto, the statues of Apollo attended by the nymphs and the Horses of the Sun were moved to the Wood of Apollo's Baths.

4I. Three iron grills, placed before three parallel doors, were designed so that the bars converged at the top of the center door to suggest the rays of the sun.

42. The allee d'eau is the path leading from the North Garden (Parterre du Nord) to the Neptune Basin. In 1670 , fourteen short fountains were placed along its length in two parallel rows, each one composed of a group of three children supporting a flat basin. Eight additional groups were added in 1678 , and in 1684 the original lead statues were replaced by twenty-two bronze replicas. 
pyramid, which Monsieur Girardon carried out with even more beauty than the drawing possessed. Thus this bas-relief is perhaps one of the most beautiful ones which had ever been created up to that time. 43

During that time, Monsieur Colbert and virtually the whole Court, having considered that what remained of the small former château of Versailles had neither proportion nor rapport with the new buildings that had been added, attempted to convince the King to have that little château torn down, in order to have the entire palace finished off with the same style and same construction as what was newly built.

\section{MY BROTHER'S DESIGN FOR A NEW CHÂTEAU AT VERSAILLES}

My brother was ordered to make a design of that building; he made a plan and elevation of it which were heartily approved not only by the King, but also by his Council, to which he summoned all the princes, several dukes, and some Marshals of France. But the King still wanted to retain the little château. They tried in vain to tell him that its ruin was impending, and the walls were buckling in several places; he was suspicious of the design, and said in a loud voice which seemed moved by anger: "Do as you please, but if you tear it down, I will have it rebuilt just as it is, without making the slightest change." Those words gave new strength to the château, and made its foundations unshakable.

One day, Monsieur Colbert took Monsieur Huygens to Versailles to show it to him. He admired everything; but, having seen a very tall tower on the causeway of the Clagny pool, 44 he asked me to what purpose they had built that tower. I told him that it was to raise the level of water in the pool.

"Is it because they want to build a fountain on that tower?" he asked.

"Not at all," I answered him; "it is to make it flow from there into the reservoirs, and from the reservoirs into all the fountains."

"It was not at all necessary," he told me, "to bring the water up to that tower; the pump would have carried it just as easily from the pond into the reservoirs, without any intermediate storage, and the expense of a tower is assuredly quite useless."

I comprehended the matter in that same instant, and I related this to Monsieur Colbert, who agreed without hesitation, and added: "What can I say? One has to pay for one's apprenticeship." But what is far more astonishing is that they made the same mistake at Marly, where they built a tower which was even wider and taller, and

43. The Pyramid Fountain, located in the North Garden, is commonly attributed to Le Brun, not Claude Perrault. Constructed between 1669 and 1672 , it is one of the oldest ornaments in the entire park at Versailles. The bas-relief depicts nymphs frolicking in a river.

44. The Clagny reservoir, located northeast of the palace, had supplied water since at least 1639 . Construction of a special pump was undertaken in 1664 and completed in 1666; the pump was destroyed in 1684 for the expansion of the north wing. The pool itself was eventually drained in 1736 , having become a public sewer as the town of Versailles increased in size. 
at incomparably greater cost than that of the Versailles tower, and yet which is no less useless: because with the same degree of force that raises the water up to the immense height of this tower, one could force it through the conduit pipes into the reservoirs of Versailles, without building a tower. I did not interfere at all in this project, and since Monsieur Colbert knew as much as I did about the business, I did not think I ought to speak to him about it, and did not even consider doing so.45

\section{SURVEY TAKEN FOR DIGGING THE CANAL OF VERSAILLES}

When the canal of Versailles was proposed, Sieur Jolli, master of the pump on the Pont-Neuf, 46 and to whom one listened with great attention at that time because he knew a great deal about water and moving forces, surveyed the terrain, and said that there was an incline of ten feet between the place where they were going to begin it and the place where it was supposed to end. If that had been true, the enterprise would not have been possible, because it would have had to have been raised by ten feet at one end, and the water would not have stayed in it without our going to incredible trouble and expense over the supporting earth. Monsieur Colbert sent for the gentlemen of the Academy of Sciences, and ordered them to survey the terrain where we wished to situate the canal. They found only two feet of incline, and we undertook construction on their word. What they had said was found to be so accurate that, when the canal was completed, no more than two or three inches of error were found along the entire length, which is nine hundred fathoms by thirty fathoms wide. The canal which crosses it, and which goes from the Trianon to the Menagerie, 47 is forty fathoms wide. Such precise determination was due not only to the skill of the surveyors, but also to the excellence of the level, which was unrivaled at that time.

This excellence consists of three things in particular: first, that instead of the thread that masons put in their levels, the gentlemen of the Academy use a woman's hair, very long, to mark the uprightness of the level with an infinitely greater precision than the string that is in ordinary levels; and second, that this hair is encased in a tube of sheet metal, which prevents the wind from moving it in any manner.

45. In the manuscript, the words "and did not even consider doing so" were added later in a different ink.

46. The Pont-Neuf, completed in 1604 and Paris's oldest surviving bridge, had a pump system to supply water for the Louvre. According to documents in the French National Archives $\left(\mathrm{O}^{1}{ }_{17} 6_{22}\right.$, dossier 2), Denis Jolly would later be accused by Perrault of embezzling over fifty thousand livres in his work at Vincennes and Versailles between 1664 and 1667, a charge based upon a confession by Jolly's brother-in-law.

47. The so-called Porcelain Trianon palace, which existed from 1670 to 1687 , was a favorite dwelling of Louis XIV and Madame de Montespan. After she fell from his favor, the palace was remodeled by Hardouin-Mansart in 1687 , in its distinctive pink marble and stone. The Little Canal which forms the transverse axis of the Grand Canal (or Canal of Apollo) had a Menagerie at one end, but this was later moved to a location east of the Trianon and no longer exists. 
There is an opening in this pipe, at the point where the hair indicates the plumb, which is closed off by a glass lens that prevents the wind from entering, and allows one to see inside. The third thing consists of a telescope on the cross-piece of the level; this telescope fixes the sights, which always vacillate when the level has no scope, so well that one can measure accurately distances of one and two hundred fathoms, without being off the mark by a hair's breadth. None of the laborers could comprehend how one could arrive at such accuracy of operation, because with their ordinary levels they could not survey a distance of thirty fathoms without being off by three or four inches.

\section{EMERGENCY WAR FUND SET AT SIXTY MILLION, AND HOW THIS AFFECTED THE KING'S BUILDINGS}

During this time, the war having become more heated than ever, $4^{8}$ the King was given to understand that in order to fight with all the success he deserved, there had to be a fund for war emergencies in the amount of sixty million [livres] a year, at the rate of five million per month. The King made this proposal to Monsieur Colbert, who was horrified, and who said at first that he did not think it was possible to furnish that amount. The King told him to think about it, and to bring him a man who would undertake to rise to the task if he himself did not wish to become involved. Monsieur Colbert did not visit the King for a fairly long while, working at home and sifting through all his papers, without our knowing what he was doing, much less what he was thinking.

Finally, after a considerable period of time, he told me to go to Versailles, to bring to the King the plans of several projects which he needed to have resolved. The King, after having examined these, told me to say to Monsieur Colbert that he should come to Versailles the following day, and that they would have an advisory meeting. He went, and things went back to normal. It was rumored that he had made the resolve to retire, seeing how difficult it would be to raise that sum of sixty million, in addition to all the other expenses of state, but that his family had persuaded him not to concede the match, and that it was a trap laid for him, to destroy him by thus separating him from what was going on. For my own part, I would like to believe that it was his love of the public good, combined with the knowledge that no one could handle such a difficult predicament better than he, which made him want to confront this task for the good of the kingdom.

This event, or rather this horrible increase of expense, marks one of the most important periods for a long time. Until that time, all the bills of state were paid on

48. War was declared against Holland in 1672 , with the intent to expand French territory and take control of commercial routes from the Dutch United Provinces. The Dutch allied with Spain, the Holy Roman Emperor, and several German princes against the French incursion. When a treaty was signed in 1678, France controlled Flanders, Ghent, and the disputed territory of Franche-Comté. 
the ordinary day they were due; from then on, annuities, of which many were cut entirely, were stretched out over sixteen or eighteen months. For the buildings, orders which, having been signed in the morning, had often been paid in the afternoon, were hardly ever paid sooner than several months later, by virtue of the fact that distributions were made according to the funds available. The Treasurer of Buildings, who usually had fifty thousand écus or two hundred thousand francs ${ }^{49}$ left over at the end of his fiscal year, which he put back into the hands of his colleague who carried out those duties, ${ }^{\circ \circ}$ now found himself usually short by a similar amount, and having to wait a long time for reimbursement. We noticed that until then, whenever Monsieur Colbert went into his office, he could be seen sitting down to work with an air of satisfaction, rubbing his hands with joy over the tasks he was going to get out of the way; but afterwards, he rarely sat down in his chair to work without an air of chagrin, and even a sigh. Monsieur Colbert went from being smooth and even-tempered, to being difficult and making difficulties for others, with the result that we took care of nowhere near as much business as we had during his first years of being Superintendent of Buildings.

49. The franc was equivalent to the livre; the sum referred to here is from one hundred fifty thousand to two hundred thousand livres.

5o. Perrault probably alludes here to Colbert, as the treasurer's "colleague" in charge of buildings.

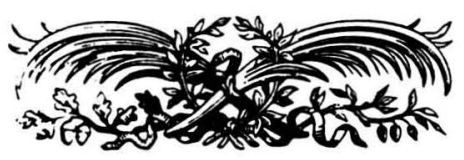




\section{Part 5 \\ PUBLIC SERVICE, PRIVATE STRUGGLE}

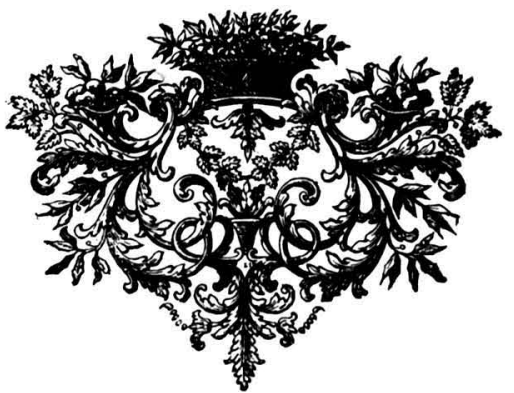

\section{HOW MY BROTHER THE RECEIVER GENERAL WAS OUSTED FROM HIS POST}

I have forgotten to tell you here how my brother the Receiver General of Finances of Paris [Pierre] was ousted from his post, and what we did, though in vain, to see justice done to him by Monsieur Colbert. The thing was as astonishing on Monsieur Colbert's part as anything else he did in his life. In order to understand the matter well, one must take it from the beginning.

My brother had passed a considerable time working as an assistant in handling unanticipated revenues, first with Monsieur de Vassan, the father of the one you knew, and later with Monsieur Sabatier, ${ }^{1}$ where he was chief clerk and where Monsieur Colbert was also a clerk, but subordinate, and finally with Monsieur Duhousset, who hired him for the same position by purchasing from Monsieur Sabatier the post of Treasurer of Parties Casuelles. ${ }^{2}$ After several years of carrying out these duties, Monsieur Duhousset had him purchase the post of Receiver General of Finances of Paris, which had previously belonged to Monsieur Bonneau, 3 an associate of Monsieur Duhousset. My brother held that post for ten years, from I654 to I664.

During this whole time, receipts were so difficult to collect that by the beginning of 1664 , my brother found himself four hundred thousand livres in debt, more or less, which was the particular result of the King having remitted to the people everything that might have been left over from the taxes ${ }^{4}$ of those ten years, a generosity that would have been admirable if it had not been done at the expense of the Receiver

I. François Sabbathier, or Sabattier, was a treasurer of parties casuelles (see below, note 2) who declared bankruptcy around 1640 .

2. Parties casuelles were the revenue derived from a type of yearly fee paid by officers of justice and finance. Equivalent to one-sixtieth of the purchase price of the office, it ensured the holder's right to sell, give, or will the office to someone else; it was also assumed to safeguard the propriety of the holder's actions (Pierre Clément, Histoire de Colbert et de son administration, 2d ed. [Paris: Didier, 1874], 2:530).

3. Thomas Bonneau, a farmer-general and tax collector.

4. Perrault's original term is taille, a tax levied upon the common people, from which nobles and members of the clergy were exempt. 
Generals, to whom these surpluses belonged, and who were almost all ruined because this debt was not recovered. Monsieur Fouquet, who was then the Superintendent, was appealed to in vain; he did not then or ever provide funds to replace the surpluses which were returned to the people for free. I remember having heard my brother say many times, speaking to others who were assigned to the general receivership of Paris, and who were asking for their payment: "You are complaining to me, and with reason; but you should rather feel sorry for yourselves. Go tell everyone, but particularly Monsieur the Superintendent, that I am keeping back your money, that I am a cheat and a thief; I will be delighted, because since it is his duty to create a fund to replace the surpluses that the King has given away, perhaps that will force him to do it, to put an end to your cries and complaints, which are most reasonable and legitimate."

When Monsieur Colbert was put in the place of Monsieur Fouquet, all Paris, and especially all the businessmen, came to my brother to offer their respects and congratulations on this promotion, because no one was unaware of the former friendship that had existed between him and Monsieur Colbert. However, this rise in the fortunes of Monsieur Colbert was my brother's complete ruin. It was believed that the reputation that Monsieur Colbert wanted to establish with the King, as a man of perfect integrity, led him to treat my brother with a harshness he would not have shown to another.

Since my brother was being horribly persecuted by those he owed, he thought that he could borrow a few deniers 5 on account, from the 1664 budget, in order to discharge the most pressing debts. But Monsieur Colbert, who rigidly observed the orders and rules which he had imposed upon himself for the administration of finances, and who had fixed a certain day for the payments that the Receiver Generals had to make into the royal treasury, and who had been informed by Monsieur Olivier, Bailiff of the Chain 6 and the official in charge of recovering those deniers, that my brother was not making the payments in their entirety, wanted to know the reason why.

My brother, who was more intimidated than he should have been, went into hiding, and as a result Monsieur Colbert summoned me to him, and said to me with every mark of kindness: "How is it that your brother is not making his payments, as it has been agreed? I am angry about this irregularity, and I would rather it had cost me ten thousand écus of my own money, and that this had never happened." I answered him that I was very surprised by what he was telling me, that I had no knowledge of my brother's state of affairs, and that I would go forthwith, if he should agree, to find my brother and learn about the situation from him; and that nevertheless I could not thank him too much for the good will he gave evidence of feeling toward my brother, and begged him to continue it.

5. A denier, the term deriving from the Latin denarius, was equivalent to a twelfth of a sou, or onehundred-forty-fourth of a livre; Perrault may therefore have intended to minimize the extent of his brother's borrowings. Deniers d'État, however, was also a technical term meaning "revenues of state."

6. The "bailiff of the chain," who wore a gold necklace or bracelet to indicate his rank, was empowered to carry out the orders of the King or the Chancellor of the Council. 
I learned from my brother what I have just related, and that the fear of being imprisoned by his most troublesome creditors had made him borrow some funds on account in order to repay them.

I returned to make my report to Monsieur Colbert, representing to him that my brother had only been reduced to that state because he had never been reimbursed for the surplus funds given to the people. This reply having been given to Monsieur Colbert, on the very next day he had the post of Receiver General sold to Monsieur Sonnin, 7 for a sum far below what it was worth and what my brother had paid for it; at the same time he removed my brother from the exercise of that same duty, and gave it to Monsieur Coquille, ${ }^{8}$ one of the two other Receiver Generals, his colleagues. The same day, he appointed Monsieur Marin, 9 Director of Finances, to make my brother submit an accounting for his years of service. The whole thing was carried out with extraordinary harshness, and everyone dealing with finances was horrified.

In the course of the appeals that my brother made to Monsieur Colbert, Monsieur Colbert once said to him: "Tell your brother to talk to me about your affairs." The very next morning, I went to his office, and told him that undoubtedly my brother had been wrong to make use of some deniers from the current year to discharge debts from the previous years, but that the error was quite excusable, since he saw himself being threatened daily with being thrown in prison by his creditors, which could not happen without his reputation being ruined and without causing mortal grief to his wife and whole family; considering the heart of the matter, he was owed great sums by the King, and would not have fallen into this unfortunate situation if they had been paid. Monsieur Colbert answered that my brother was in the same set of circumstances as the two other Receivers General, his colleagues.

I countered that my brother had told me that his situation was very different from that of his colleagues, of whom one was the nephew and the other a friend of Monsieur Marin, ${ }^{\text {Io }}$ the Director of Finances, who had shown them favor on every occasion, obtaining for them capital and transfers of funds, whereas he let fall onto my brother's shoulders as many worthless stocks and troublesome debts as he could. Moreover, there was another difference between him and them, which was that all my brother's receipts were acknowledged by clerks in the office of the treasury, because he had made all his payments in currency, whereas his colleagues' receipts were in the form of vouchers, in which they listed the bank notes. This led to very high profits, because often, in a voucher of five hundred thousand francs, one might

7. Jean-Baptiste de Sonning later owned a lavish house in the Rue de Richelieu that was described in J.-E Blondel's Architecture française (book 5 [1754], chap. I6).

8. Claude Coquille is documented in the National Archives $\left(\mathrm{KK}_{35} 6\right)$ as having been a Receiver General of Finances in 1671.

9. Denis Marin (c. 1600-1678) was a Commissioner of Finance who had been a clerk for the King's household and a secretary to Louis XIII. As an illustration of the rampancy of nepotism, his daughter married Thomas Bonneau's son, his nephew was Claude Coquille, and his second wife was Colbert's cousin Marguerite.

10. Perrault here refers to Coquille and to either Thomas Bonneau or his son Charles. 
list twenty thousand écus ${ }^{\mathrm{II}}$ in bank notes, which had not actually cost more than ten or twelve thousand francs, the surplus going to the profit of the Receiver General and the Treasurer of the bank. These profits could in some way have compensated his colleagues' loss, and put them in a different financial condition from that of my brother.

My arguments did not please Monsieur Colbert, and he told me that I should make a choice; that I should consider whether I truly wanted to continue my service with the King's buildings, and that if that were the case, I should never again speak to him of my brother's affairs; if I should wish to continue to discuss them, I should retire from my post, and then he would listen to me and reply. I replied to him that I had no other choice to make but to be silent, and to conform myself entirely to his wishes.

My brother, after this answer, continued his appeals for a long time, giving all the explanations that could be desired, up to the point of showing that according to his accounts, which were being held in the Chamber, ${ }^{12}$ the King owed him and still owes him (because he was never paid) more than three hundred thousand livres. In the middle of these appeals, Monsieur Colbert told my brother once more that I should speak to Colbert about his affairs. Having therefore presented myself before him, I was told: "Your brother is a clever man, and I have known this for a long time; he knows that I am one of his former friends. He has counted upon this, and has believed that he could play this trick on me with impunity."

"Monsieur," I answered him, "forgive me, please, if I say that I don't see what trick he has played on you."

"The trick that he has played, is that with the money of this year, he has settled half of the debts which today he asks me to repay in their entirety."

"Ah! Monsieur," I exclaimed, "could you harbor such an idea about a man whom you say is your friend, and whom you have known for such a long time? My brother will endure without protest the poverty to which he is reduced, but he will never be able to bear the chagrin of appearing in your mind to be a dishonest man. If there is one fault which we have in our family, it is our lack of regard for wealth and our scorn for it, and far be it for any one of us to be capable of such a cowardly act." On these words, I withdrew.

I had several more meetings with Monsieur Colbert, which led to nothing more than making me close my mouth, in the same way as before. Finally, one day I begged him to give my brother some small commission, to allow him to subsist; but I was unable to obtain anything for him, and my brother remained without a position and without even a valet to serve him. Among his creditors, there was one named Monsieur Chartier, a man who was considered to be very harsh and absolutely

II. Equivalent to sixty thousand francs or livres.

12. This term refers to a judicial chamber of court, where Pierre Perrault's delinquency would have been tried, or to a chamber of parliament, where records would be kept. 
implacable. However, instead of hounding my brother, he defended him, and supported his cause in regard to and against all the other creditors, saying this to me: "If your brother had my wealth in his hands, I would know how to get it back; but this is a man who has had his throat cut behind the bushes. Far from crushing him down, I will ease his burden in every way I can."

My brother's reputation was such that in the whole period of his adversity, which lasted sixteen years, two of his friends gave him all their cash to hold in trust, amounting to more than forty thousand écus, which showed great confidence in his integrity. My brother sometimes conveyed to Monsieur Colbert that among his creditors were three or four of his closest relatives, whom he would have been most happy to be able to satisfy; that their debts put together did not amount to more than fifty thousand livres; that he begged Monsieur Colbert to grant him that sum, deducted from the three hundred thousand livres which the King owed him, and that, if Monsieur Colbert did him that kindness, he would not die with so much grief. Monsieur Colbert was harsh enough to refuse him, and allowed him to die without making him any reparation. ${ }^{13}$

\section{HOW I ASKED MONSIEUR COLBERT FOR HIS APPROVAL OF MY MARRIAGE}

When I got married, I went to Monsieur Colbert to seek his approval. ${ }^{14}$ As soon as I had told him the person's name, and who her father was, he asked me how much they were giving me in dowry. I told him that they were giving me seventy thousand livres.

"That is too little," he said to me; "believe me when I say that I am thinking of your interests. You see what I have done for Monsieur du Mets; is I will certainly do no less for you. I will find you a girl, from a family in business, who will bring you a much more advantageous dowry. But," he pursued, "is this not a marriage of affection you speak of?"

"I have only seen the girl," I replied, "one time since she was out of the convent, where she was put at the age of four; but I have known the father and mother for more than ten years, on account of our having lived together very companionably since that time. I know them, they know me, and I am confident that I will live with them perfectly well. This, Monsieur, is the principal reason that persuades me. I would be very upset to encounter a father-in-law who would always complain that I did nothing, and who would want me to importune you every day for the means of doing something. I do not want to come to that point.

13. Pierre Perrault died in 1680, three years before Colbert.

14. On I May 1672, at the age of forty-four, Perrault married nineteen-year-old Marie Guichon, with whom he would have three children: Charles-Samuel (b. 1675), Charles (b. 1676), and Pierre (1678-1700). His marriage contract is recorded in the Documents du Minutier Central (88:224).

I5. See Part 3, note 22. 
"You give me greater emoluments than I deserve, but aside from that I make no profits. Not only do I receive nothing from all the transactions that take place, but as regards the letters patent you give me for lodging, privileges, and other such things, not only do I take none of them, but I contribute my own parchment, my own trouble, and my clerk's, without profiting by anything more than a bow, and most often a clumsy one at that. I am quite satisfied that this should be so; but there are some fathers-in-law who would not be satisfied at all."

"I believe," said Monsieur Colbert, "that you are right; carry out your business, and rest assured that I will take care of you." I was very happy to have found the opportunity of letting Monsieur Colbert know precisely how I was serving him, and that I relied entirely upon him for the rewards of my work.

\section{RESOLUTION TO CLOSE THE TUILERIES GARDEN NOT CARRIED OUT}

When they had finished replanting the Tuileries Garden, ${ }^{16}$ and putting it in the state you see it in today, "Let us go," he said to me, "to the Tuileries, to have the doors blocked up. We have to preserve this garden for the King, and not allow it to be ruined by the people, who, in less than no time, would completely spoil it." The decision seemed to me to be very severe and very distressing for the whole city of Paris. When he had reached the main path, I said to him: "You would not believe, Monsieur, the respect which everyone, down to the most insignificant bourgeois, has for this garden. Not only do the women and small children never take it into their heads to pick any flowers, but they do not even touch them; they walk here as if they were all very reasonable people. The gardeners, Monsieur, can bear witness to this. It would be a public affliction not to be able to come here to walk about, especially now that no one may enter the Luxembourg Gardens or the Hôtel de Guise."

"It is only the idlers who come here," he said to me.

"People come here," I replied, "who are recovering from illness, to take the air; they come here to talk about business, about marriages, and about everything which is dealt with more appropriately in a garden than in a church, where in future people would have to meet. I am persuaded," I continued, "that the gardens of kings are so large and so spacious only in order that all their children may walk there."

$\mathrm{He}$ smiled at this speech, and since meanwhile most of the Tuileries gardeners had presented themselves before him, he asked them if the public did not wreak havoc in their garden. "Not at all, Monseigneur," they replied, almost in chorus; "they are content to walk about and to look."

I6. The Tuileries Garden was redesigned by André Le Nôtre after I66r. He had served as its official gardener since the age of twenty-four, in 1637 , and both his father and grandfather had held the same post. 
“These gentlemen," I added, "even get something out of it, because the grass does not grow back as quickly in the pathways."

Monsieur Colbert made a tour of the garden, gave his orders, and said not a word about closing the entrance to anyone at all. I derived considerable joy from having in some way prevented this promenade from being taken away from the public. If ever Monsieur Colbert had had the Tuileries closed, I do not know when they would have been reopened. That action, however, would have been praised by the whole Court, which never fails to applaud ministers, particularly when they appear to be showing zeal for the King's pleasure.

\section{HOW LULLI HAD THE OPERA}

Around that time, Lulli ${ }^{17}$ managed to obtain the sole rights to compose operas and to receive all profits from them, which were quite considerable. Operas had first been established by a small one in which the Sarcaman ladies sang and played the principal roles. ${ }^{18}$ It was first sung in the village of Issy, in a goldsmith's house, where it was very successful. I was taken to the first performance, which was very agreeable. The Abbé Perrin ${ }^{19}$ had composed the words, and Cambert ${ }^{20}$ the music. The fortunate success of this pastoral in music led them to undertake other operas, which were performed in public with applause and with a great deal of profit for the author, the composer, and for all the actors.

Lulli, who until that time had been scornful of their music, upon seeing the great gain they were making from it, asked the King to grant him the sole right of creating operas, and to receive all their profits. Perrin and Cambert were opposed to this, and even Monsieur Colbert himself, who did not consider it fair to dispossess the inventors or at least the first promoters of this form of entertainment in Paris, did not agree at all, finding moreover that it was more suitable, in order for the French to perfect their musical studies, to allow everyone the freedom to compose operas, the lyrics as well as the music, in the same way that it works for comedies and tragedies, that each person may write them however he likes, and offer them to actors to be performed.

Lulli went to the King to demand this grant with such vehemence and such

17. Jean-Baptiste Lully or Lulli (1633-1687) was born in Italy and spent most of his life in France. He was named Superintendent of Music and was given sole charge of the Royal Academy of Music in 1672 .

I8. This opera was entitled "The Pastoral in Music" or "The Opera of Issy," according to Bonnefon (Mémoires de ma vie, p. 127), and was presented in the private home of Monsieur de la Haye and subsequently at the château of Vincennes, before the King. Madame and Mademoiselle Sarcaman were a mother-daughter team of actress-singers who appeared in this work.

19. The Abbé Pierre Perrin (1620-1675) was in the service of Gaston d'Orléans, Louis XIV's uncle, who died the year after the opera was performed.

20. Robert Cambert (1628?-1677) was Superintendent of Music for Anne of Austria, Louis XIV's mother, and was also organist of the Church of Saint-Honoré. He later became Superintendent of Music for King Charles II of England. 
importunity that the King, fearing that Lulli would abandon everything out of spite, said to Monsieur Colbert that he could not do without that man in his entertainments, and that it was necessary to accord him what he sought. This was done on the very next day, to the great astonishment of many people, especially me, because I knew that Monsieur Colbert was of the complete opposite opinion. Two or three days later, I heard him say that the courtiers were censuring this gift to Lulli, saying that this man was going to gain immense sums of money, and that it would have been better to allow it to be shared among several musicians; this would have inspired them to emulate and surpass one another, and therefore to bring the music to the ultimate degree of perfection.

"I hope," said Monsieur Colbert, "that Lulli will earn a million by writing operas, so that the example of a man making such a fortune by composing music may inspire all the other musicians to make every effort to arrive at the same point as he." So true is it that ministers always know how to find reasons to justify the plans and decisions of their master.

\section{HOW LULLI OBTAINED THE GREAT THEATER HALL OF THE PALAIS-ROYAL}

After Lulli had obtained his grant, he asked me, jointly with Monsieur Vigarani, who made the theatrical machines and decorations, to solicit Monsieur Colbert on their behalf to ask the King for the great theater hall of the Palais-Royal, ${ }^{21}$ for performing their opera. I had the honor of putting this proposal before Monsieur Colbert on their behalf, and he listened to me with favor. I remember that I said to him in this instance that one of the things that Roman emperors had taken care to observe was to give games and spectacles to the people, and that nothing had contributed more to their winning the hearts of the people, and keeping them in peace and tranquility; that today it was not common practice for rulers to take that kind of care, but that certainly it would be a very pleasant thing for the people of Paris if they could at least have the satisfaction of those kinds of diversions in the palace of their prince.

"You are eloquent," Monsieur Colbert replied to me with a smile; "I will consider it." He then spoke of it to the King, who was pleased to accord this favor to Lulli. Then they asked for a thousand écus to refurbish the place and to put it into a proper state; this sum was granted to them, and I might say that they were again partly indebted to me for this. For all these good turns, I received nothing other than their having had the decency not to take my money at the door; but neither did I wish for

2I. The Palais-Royal was constructed in I633 as a residence for Cardinal Richelieu. It contained a theater which was the site where Moliere's plays were performed between I66I and 1673; Moliere collapsed upon its stage during his final performance. The theater was burned in 1763 . 
anything more, and I only did in these circumstances what I have always done on the occasions when I have done someone a favor.

\section{IDEA OF BLOCKING OUT ALL THE WINDOWS THAT LOOK OUT OVER THE PALAIS-ROYAL}

I believe that I also did a considerable favor to all the owners of private houses that have a view of the Palais-Royal garden. ${ }^{22}$ Mademoiselle de la Vallière ${ }^{23}$ lived at the Palais-Royal, and apparently those views bothered her. Monsieur Colbert, who deemed it proper, told me that it would be necessary to raise the walls of the garden enclosure to the height of the roofs of the surrounding houses, and to wall in all its windows. This would not only have spoiled all those houses, but would have given the appearance of a prison or a convent to the garden, as beautiful as it is.

This made me shudder. I said to Monsieur Colbert, in order to postpone a bit the execution of this order, that the best worker for the job was busy with something he was finishing at Versailles, and that as soon as he finished that task, he could be ordered to raise the wall. Monsieur Colbert approved my suggestion, and the thing was put off. A few days later, Mademoiselle de la Vallière left the Palais Brion, ${ }^{24}$ and there was no further mention of raising the walls of the enclosure or of walling in the windows. If that work had ever been begun, it would have been completed, and it is possible that the owners of those houses would never have been able to restore things to their former state.

\section{ADVERTISEMENTS FOR OFFERING WORK ON BUILDINGS AT REDUCED FEES}

In the year $167^{-},{ }^{25}$ the King went to visit the fortifications which Monsieur de Louvois ${ }^{26}$ had had built in various places in the kingdom. The King came back very

22. Perrault himself owned one of those houses, in the Rue Neuve des Bons Enfants on the northeast side of the garden.

23. Louise-Françoise de la Baume le Blanc de la Vallière (1644-1710) was a maid of honor to Henriette of England, Louis XIV's sister-in-law. She was the King's mistress until the advent of Madame de Montespan (see Part 2, note 24) in 1667. She retired to convent life in 1674 and took Carmelite vows in 1675 .

24. Several buildings connected to the palace along the Rue de Richelieu had formerly been rented to the Duke de Damville, who was also Count de Brion. From about I650 to 1680, this wing was referred to as the Palais Brion (Brion Palace).

25. The date is incomplete in Perrault's text.

26. François-Michel le Tellier (1639-1691), Marquis de Louvois, was the son of the Chancellor Michel le Tellier. He was the King's Secretary of State for War from 1662 onwards, during the war with Holland, and was credited both with the effective reorganization of the French army and with great ruthlessness. The Grande Encyclopédie (no date, vol. 22bis, p. 688) cites a letter from Louvois to his deputy Robert, in which he states: "I beg you not to tire of being wicked, and to push things forward in this manner with all possible rigor . . . When twenty houses have been destroyed in a day, you must destroy as many again the following day, and not tire of it." 
satisfied, but especially with how little they had cost, in relation to the great size and extent of the projects, which Monsieur de Louvois had not failed to exaggerate. Upon his return, he said to Monsieur Colbert:

"I have just seen the most beautiful fortifications in the world, and the most extensive; but what astonished me the most is the small expense incurred. How is it that at Versailles we spend frightful sums, and we see almost nothing accomplished? There is something in this that I do not understand."

Monsieur Colbert was sharply hurt by this reproach, although he responded to the King with very good reasons for the difference between army construction sites, where the soldiers only receive a very small wage, and sites like those at Versailles, where the laborers are paid for a full day's work; and work on fortifications could all be seen in a glance, and was all of the same nature, whereas the work at Versailles was spread out over a thousand places, almost every task being of a different type. He believed that the King had been misinformed on this point, and that undoubtedly he had been made to understand that everything being done at Versailles was too expensive. In order to disabuse the King of this very false and very ill-founded idea, he ordered that in future all work on buildings would be advertised for reduced fees, and so that the thing would be done with enough show, he wanted signs advertising all these jobs to be put up at streetcorners, so that we could receive offers from all the workers.

For me this meant a fearful increase of work in preparing all these signs, which were very numerous and all incredibly detailed, because each type of work, in each specialty, was specified. Nothing useful came of this; on the contrary, it caused a great problem, because the worst workers used low fees to drive away the best workers, and those who were most capable of providing good service. There were carpenters who, having only flawed wood in their lumber yards, did such poor work for Versailles that when the pieces out of which they had made casement windows were closed, one could see out almost as clearly as when they were open.

There were some good workers who continued to work as they had been accustomed, and when they were told that, if they were paid on the basis of the advertisements and the deals which had been made with their colleagues, they would be ruined, they replied: "We don't worry about advertisements; we will still do good work, and we are certain that Monsieur Colbert is too just not to pay us what it is worth." And in fact that was what happened: they were paid at the ordinary scale, and no one paid any attention to the deals made with the other workers. It is an evil thing to have anything at too cheap a price. A superintendent, or the controllers under his authority, must set the prices, but prices reasonable for the jobs, and then must give them to the best workers. This proposition may seem a bit paradoxical, but it is very true, and one cannot be well and faithfully served except by following it.

This change made my work so onerous, and Monsieur Colbert became so difficult and so peevish, that there was no longer any way that I could keep up with it or bear 
with it. At this same time, he wanted Monsieur de Blainville, his son, who was then called Monsieur Dormoy, ${ }^{27}$ to work under him in buildings affairs, and to do nearly my whole job. This made me wish to abandon the whole thing to him, knowing well, moreover, that Monsieur Colbert would not be displeased, and that his son would in this way have the whole honor, after Monsieur Colbert, of everything that would be done with buildings. Monsieur Colbert complained to me that there was a great number of workers' accounts which had not been settled, particularly of those undertaking work on the Louvre-and which still have not been settled in this year of $\mathbf{1 7 0 2}$ in which I write this memoir, a sign that it was not my negligence which delayed their execution, since it has been more than twenty years since I left them behind. I tried in vain to show him that the great amount of pressing business had kept me so occupied that it was impossible for me to do anything more, besides which he had never given me either the order or the authority to settle these accounts, which were of such great importance. He did not cease his continual grumbling, and blaming me for a fault which was purely his own.

This went so far that I was forced to offer my resignation, which he accepted with all the more willingness since he was pleased, as I have said, to promote the career of his son. That did not happen, since, as he was a very young man who liked his pleasures, it was not possible for him to live up to half the demands of such a vast and troublesome post, ${ }^{28}$ the difficulty and extent of which Monsieur Colbert had never understood, because I had never made a show of the trouble I had to take, according to the unfortunate habit I have always had of not speaking about the trouble I go to in the services I render. I learned afterwards that Monsieur Colbert had said: "Buildings are a bottomless pit; the more I work on them, the more difficulties I encounter. Finances have given me no trouble by comparison; I have regulated them all with ease, and I cannot get out from under the problems that buildings give me."

I therefore put all my papers on buildings in good order, and turned them in to him with a precise inventory, and retired without making any show or noise. When Monsieur Colbert died, 29 I was treated in a somewhat strange manner: my post, which was worth twenty-five thousand écus, ${ }^{30}$ was bought back from me for the sum of twenty-two thousand livres; and Monsieur Le Brun and Monsieur Le Nôtre were each given twenty thousand livres as a reward for their excellent and pleasing services, a sum provided out of the price of my post, which was sold for about sixtysix thousand livres.

27. Jules-Armand Colbert, Marquis d'Ormoy and de Blainville (1663-1704), was Colbert's fourth son.

28. In 1682, when d'Ormoy took over Perrault's duties as Superintendent of Buildings, he was nineteen years old. Due to his incompetence in the position, he was later forced to resign on the very day of his father's death, and was paid a sum of nine hundred thousand livres (Bonnefon, Mémoires de ma vie, p. 133).

29. Colbert died on 6 September 1683 , after having suffered from chronic inflammation of the kidneys for several years.

30. Equivalent to seventy-five thousand livres. 
Finding myself at liberty and at rest, I thought that having worked with continual diligence for nearly twenty years, and being more than fifty years old, I could properly take my ease and devote myself to raising my children.

With this plan in mind, I moved to my house on the Faubourg Saint-Jacques, which, being near the secondary schools, ${ }^{3 \mathrm{I}}$ made it very easy for me to send my children there, having always believed that it is better for children to sleep in their father's house, when that can be done conveniently, than to make them boarders in a school, where morals are not as strictly observed. I gave them a tutor, and I myself had fairly frequent charge of their lessons.

Monsieur Colbert having died, and Monsieur Louvois having been made Superintendent of Buildings, we all went, Monsieur Charpentier, Monsieur the Abbé Tallemant, Monsieur Quinault, and I, to Fontainebleau, ${ }^{32}$ to ask Monsieur Louvois whether he wanted us to continue carrying out the duties of the Little Academy of Inscriptions and Medals, as we had done under Monsieur Colbert. ${ }^{33}$ We composed a memorandum, and it was I who wrote it down, being the recording secretary of the Academy. This memorandum indicated for what purpose it had been established by Monsieur Colbert, which was to have near him men of letters whom he could consult in an infinite number of things having to do with buildings, where it is necessary to have wit, and which for the most part cannot be done well without a knowledge of how they were done by the ancients; and also to make descriptions of monuments and other remarkable things that would be done, which would merit being sent to foreign lands and being left for posterity.

This memorandum was given to Monsieur Louvois, who gave it to the Chancellor, his father, to read. This document had a somewhat strange effect. The Chancellor Le Tellier had always made fun of this Little Academy, and it was a frequent subject of his jokes, as he considered that no money was more ill-used than that which Monsieur Colbert gave to those who made up rebuses and ditties. However, when he had read that memorandum, he changed from white to black, and said to Monsieur de Louvois, his son, upon returning it: "That is an institution which must be preserved with great care, because nothing can bring greater honor to the King and to the kingdom, at such small cost."

On the afternoon of that same day, Monsieur Charpentier, Monsieur Quinault, and Monsieur the Abbé Tallemant presented themselves before Monsieur de Louvois. I did not think it appropriate for me to go, fearing that Monsieur de Louvois might

3I. According to the Turgot Map of 1739, the Rue du Faubourg Saint-Jacques was situated only a few blocks south of the Sorbonne, near numerous secondary schools or "collèges," including the Collèges of Lisieux, Cholets, Plessis, and Beauvais, the last of which Perrault himself had attended.

32. The palace of Fontainebleau, a medieval castle rebuilt by François I in the sixteenth century, and whose gardens were designed by Le Nôtre in the seventeenth, is situated southwest of Paris.

33. The founding members Cassagnes, de Bourzéis, and Chapelain having died in 1671,1672 , and 1674 respectively, the Little Academy was then composed of Charpentier, Perrault; Tallemant, and Quinault (appointed in I674). 
say something which displeased me, and that in anger I might have given him a reply that was a bit too strong, and that I might have regretted afterwards. Monsieur de Louvois said these words to them: "You have until now, gentlemen, done marvelous things; but you must, if possible, do even better in future. The King will give you such good material that it will only be left to you to say admirable things. How many are you?"

"We are four in number, Monseigneur," replied Monsieur Charpentier.

"Who are they?" said Monsieur de Louvois.

"There is," began Monsieur Charpentier, "Monsieur Perrault..."

"Monsieur Perrault?" said Monsieur de Louvois; "you are joking, he was never among you; he had enough to do with buildings. And the others, who are they?"

"There is," said Monsieur Charpentier, "Monsieur the Abbé Tallemant, Monsieur Quinault, and I."

"But there are only three of you... where is the fourth?"

"I had the honor of telling you," replied Monsieur Charpentier, "that there was Monsieur Perrault."

"And I tell you," said Monsieur de Louvois, in a raised voice which indicated that he did not wish to be contradicted any further, "that he was not there."

Monsieur Charpentier was silent, and Monsieur de Louvois pursued: "Who was therefore this fourth one?"

Then Monsieur Charpentier, or Monsieur Quinault, or the Abbé Tallemant, said: "Monsieur Felibien ${ }^{34}$ came sometimes to the meetings, to read descriptions which he made of various features of the King's buildings."

"Finally we have the fourth one I was looking for," said Monsieur de Louvois. "Well then, go, gentlemen, and work with all your might."

That is how I was excluded from the Little Academy, where I would have been very happy to have been continued; but I still had to endure this humiliation.

To give myself some occupation during my retirement, I composed the poem of Saint Paulin, 35 which had a fair success, although some people who were very highly regarded for their wit and for their reputation spoke against it at every opportunity. [It is true that there were a few verses which were a bit weak, and it was only those which these ill-disposed persons knew by heart, and would recite at meetings. $]^{36}$

Then I composed the little poem of The Age of Louis the Great, which received much praise when it was read aloud to the French Academy, on the day when we met to give evidence of the joy which we felt over the convalescence of His Majesty, after

34. André Felibien (1619-1695), the Historiographer of the King's Buildings, was a founding member of the Academy of Architecture. He is documented as having become a member of the Little Academy in I683, the same year of Colbert's death, as Perrault describes (La Grande Encyclopédie, 1:194). 35. Saint-Paulin, Évèque de Nôle (Saint Paulin, Bishop of Nôle) (Paris: J.-B. Coignard, 1686).

36. The sentence in brackets was crossed out in the manuscript, suggesting that Perrault was wary of the possible effect upon his reputation if he were to state that his verses were ridiculed in public. The ill-disposed persons in question undoubtedly included Boileau. 


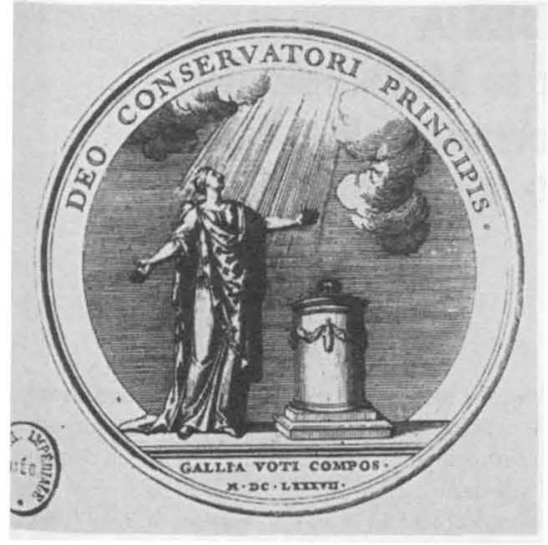

Medal commemorating the King's recovery, January 1687. Deo Conservatori Principis: For God the Protector of the Prince. Courtesy Cabinet des Médailles, Bibliothéque Nationale.

the serious operation he had undergone. ${ }^{37}$ This praise irritated Monsieur Despréaux so much that after having grumbled in an undertone for a long time, he stood up in the Academy, and said that it was a shame for such a thing to be read, criticizing the greatest men of antiquity. Monsieur Huet, who was then the Bishop of Soissons, ${ }^{38}$ told him to be quiet, and that, if it were a question of taking sides in favor of the ancients, it was more suitable for him to do so than for Boileau, because he knew them far better, but that they were only there to listen. Afterwards, Monsieur Despréaux's annoyance led him to write several epigram $3^{39}$ which only went so far as to offend me, but not to undermine my feelings concerning the ancients.

Monsieur Racine complimented me on that poem, which he praised highly, in the supposition that it was purely a jest, not expressing my true feelings, and that in actual fact I thought the complete opposite of what I had put forth in my poem. I was irked that no one believed, or at least that they pretended not to believe, that I had spoken seriously, and so I resolved to say seriously in prose what I had said in verse, and to say it in such a way that there could be no doubt of my true opinion on the matter. That was the inspiration and the origin of my four volumes of Parallels.40

[Editor's note: After this final paragraph, which was partly crossed out and rewritten in several places, the manuscript abruptly ends on its eighty-seventh page. Although there would be no mention of later works, including the Tales, it is nevertheless fitting that Perrault should have paused at this moment, in describing the most pivotal event of his literary career.]

37. The King was operated on successfully for a fistula in January 1687. On the twenty-seventh of that month, Perrault's poem was read aloud to the Academy by Louis Irland, Abbé de Lavau (d. 1694), who had been a member of the Academy since 1679 .

38. Pierre-Daniel Huet (1630-172I) was the Bishop of Soissons and Avranches.

39. Boileau published nine epigrams between 1687 and 1694 deriding Perrault's modernist views.

40. Parallele des Anciens et des Modernes, 4 vols. (Paris: Coignard, I688, 1690, 1692, 1697). 


\section{APPENDIX A \\ Charles Perrault: "Letter to Mademoiselle ... . On Sending Her the Portrait of Her Voice"}

[Note: The portrait was a popular poetic genre, detailing the idealized attributes of an admired beauty in lyrical style. The Portrait of Iris, described by Perrault as being among his earliest and most successful literary efforts, was followed by a Portrait of Iris' Voice accompanied by this introduction, which displays Perrault's lightness of touch in blending flattery and self-deprecating humor. Both poems were first published in 1659 and then reprinted in 1675, in the Collection of Various Works in Prose and in Verse (Paris: J.-B. Coignard).]

When I made your Portrait, I did not intend to represent in it everything which is lovable in you; that thought would have been too bold, and it was quite enough that I should undertake something beyond my abilities, without committing myself to the impossible. You complain, Mademoiselle, that I said nothing about your voice, as though in fact nothing but that were lacking in your Portrait, and that were the only one of your perfections that I had forgotten. However, I wish to warn you that you have a hundred others that I value infinitely more, and that I would have praised before getting to your voice, even though it is one of the most beautiful and most charming in the world; because, after all, have I said nothing about the sweetness of your conversation, which touches not only the ear, but penetrates to the soul and bewitches it? Have I praised your goodness, your generosity, your conduct, which is the loveliest and wisest there ever was? With all this, Mademoiselle, I artlessly confess that after having been so often charmed by your beautiful voice, I was wrong to have forgotten it; therefore to repair my error entirely, here is her Portrait which I send you; it is done life-size, and it is made for her alone. 


\section{APPENDIX B \\ Charles Perrault: "Speech of Thanks to the Gentlemen of the French Academy, upon his reception on 23 November 1671"}

[Note: Following the tradition that newly elected members of the French Academy were expected to deliver a formal speech of thanks, Perrault delivered this speech to a closed session of the Academy on 23 November I671. The Academicians were well aware that Perrault's nomination had been sponsored by Colbert, and many were openly hostile to his appointment. This speech attempts to deflect that hostility by conveying an attitude of self-deprecation instead of the arrogance expected of Colbert's protégé. Furthermore, it directs the listener's attention away from Perrault himself and focuses instead upon a eulogy of the King, in terms which even the most antagonistic critic of Perrault would be forced to applaud. Perrault was to employ this same technique, with markedly less success, in his poem The Age of Louis the Great (1687). The Speech of Thanks to the Gentlemen of the French Academy was published in the Collection of Various Works in Prose and in Verse (1675).]

Sirs,

When I consider the honor that I am receiving, to enter into this Illustrious Company, and at the same time I think about how little I deserve this grace, I do not know which is greater in me: either the joy that I feel over it or the embarrassment that I have because of it. Therefore, Sirs, I wondered for a long time whether I would not do better not to seek a reward which demands so many talents that I do not have. But I believed that if I do not excel in the profession of Letters, the extraordinary passion that I have for them would serve me in the place of skill, and might in itself suffice to allow me to be received among you, just as it suffices, to be a Philosopher, that one have the love of wisdom.

What also might justify my boldness and your choice both together, is that at least I can boast of well understanding the preciousness of the honor that you do me. I know that I am entering into the society of the most eloquent, the most ingenious, and the most knowledgeable men of our century, whom love of Letters alone has brought together, and whom merit alone has distinguished from other men. I know that you are the true dispensers of glory, established to give virtue the finest reward that it can receive aside from itself, and to immortalize the deeds of Heroes, while those of all other men fall into the eternal shadows of oblivion. For, Sirs, I am persuaded that distant posterity will only speak of you or of those of whom you will have spoken. When Cardinal Richelieu, that man of whom one can say that his ruling passion was to show off the greatness of his Master and of his Country; when, I say, this great figure laid the foundations of this Company, ${ }^{\mathrm{I}}$ few people saw as he did the value of what he accomplished. It was looked upon as a mark of his love for Letters; he was praised, perhaps, for having found the time amidst his important occupations to have thought of it; and it was found admirable that this great Genius, burdened with so many matters and busy

I. Cardinal Richelieu founded the French Academy in letters patent of January I635. 
establishing order in all parts of the Kingdom, should still have extended his concern to the beauty of language and the arrangement of words.

But he had quite another motive in establishing this Company, and he undoubtedly saw it not only as an act glorious in itself, but as the one among his deeds which would preserve the glory of all the rest. He knew that the flatteries of the Court and the acclamations of the people leave no trace which lingers after them, and that Fame is as careful to keep silent about great events, once they have taken place, as she is to broadcast and make noise about them in the moment that they occur. He therefore judged that since only the works of the mind are immortal, one must raise and train Workers capable of creating excellent ones, which would perpetuate for centuries to come the glory of his Prince and the memory of the services rendered to him. And because time changes all things, by a stroke of his wisdom he wished the Company to devote itself without respite to polishing our Language, and to make it as firmly fixed as possible, so as to prevent the Works made during his time from becoming outdated, and depriving the following centuries of all means of harming these Works, due to the impossibility of bringing the purity of the language to a higher degree of perfection.

It is thus true that this great Personage regarded the founding of this Company as a very important deed. It is in this spirit that Monsieur the Chancellor, ${ }^{2}$ the veritable Nestor ${ }^{3}$ of our age, less for his age than for his powerful eloquence and his consummate wisdom, wishes at times to be present at your meetings, and joyfully gives to the surveillance of this Body a part of the care which he devotes so usefully to the good of the whole State. It is in this same spirit that men of the greatest dignity and of the highest rank have had the ambition to become your Colleagues, and have believed that the title of Academician would add some new brilliance to the glorious titles with which they were invested.

And certainly, Sirs, if there is anything in the former Reign which might be envied by the present one, where nothing is lacking which might help Knowledge and Art flourish; where the generosity of the Prince is extended to all men of Letters who give some sign of an extraordinary ability; where we see the rise of the Illustrious Academy of Sciences, in which Astronomy, Geometry, and Physics find nothing either in the skies or on earth which escapes their understanding; where still other Academies train our Apelles, 4 our Phidiases, 5 and our Vitruviuses; ${ }^{6}$ if there were, I say, anything for which the present Reign could envy the past one, it would be the establishment of this Illustrious Company.

But one cannot begin too soon to polish and perfect a language which apparently must one

2. Pierre Séguier (1588-1672), a founding member of the French Academy and Chancellor of State since 1635, became the official Protector of the French Academy upon Richelieu's death in 1642. After Séguier's own death in 1672 , only a year after Perrault's reception, the King himself became the Academy's protector (see Memoirs, Part 4, p. 85).

3. Nestor, the legendary King of Pylos, was a hero of the Trojan War who typefied the wise, aged counselor.

4. Apelles was a Greek painter of the late fourth century B.C., of whom no known works remain extant.

5. Phidias was an Athenian sculptor of the fifth century B.C., credited with the friezes and decorations of the Parthenon.

6. Marcus Vitruvius Pollio was a Roman architect and engineer of the first century B.c. A translation of his work De Architectura was published by Claude Perrault in 1673, when construction had already begun upon his several designs. Perrault's naming of an architect, in a list of only three artists, also flatters the establishment of the Academy of Architecture in 1671, of which Claude was a founding member. 
day be the language of all Europe, and perhaps of the whole world; and especially a language which must speak about LOuIs fourteenth. One could not too soon train Orators, Poets, and Historians to celebrate his great actions. In fact, Sirs, however rich may be the talents that each one of you possesses, there is matter enough to make use of them all, and to exhaust them. For what subjects of Poems will not his courage and his exploits furnish to all Poets, who without the aid of fable and fiction will find the heroic and the marvelous; what harvest of praise will not the Orators encounter in the other virtues of this Prince, of which the simple recital will form Eulogies and Panegyrics? What accumulation of memorable events and brilliant deeds, for those who will devote themselves to history? What ought to be the force of their expression, to correspond to the worthiness of their material, and what skill will they not need to bring together verisimilitude and truth, and to make the future age believe what we have difficulty imagining, even when we see it.

In fact, Sirs, when this Great Prince began to take charge of his affairs himself,7 it seems that God gave him to us a second time, formed by his hand and filled with that wisdom which makes Kings reign; and we saw him in his Council with a quicker and more penetrating intelligence than that of all those whom he had called there. When the just pursuit of his rights obliged him to wage war, ${ }^{8}$ his most experienced Generals and Captains were surprised to find themselves less knowledgeable than he in matters of war, and in the exercise of military discipline; and we know that he taught them a rapid means of conquest of which neither their experience nor History itself could furnish a prior example. I do not speak of his valor or of his bravery in danger, which so often, though for different cause, made his Subjects and his Enemies tremble; these are common virtues of Heroes. But you, Sirs, who know all the beauties and all the graces of discourse, who know how difficult it is to acquire them, what was your surprise in seeing him possess this precious gift of speech in a degree of perfection which perhaps no one has ever attained by means of study and rules? If I may, let me add to what I have just mentioned a new cause for astonishment, because it concerns a matter which is more within my knowledge than any other: it is, Sirs, that there is nothing in the Fine Arts of which he does not see, of which he does not discern all the graces and all the delicacies known only to Masters; it being so true that when good sense, or rather wisdom, is found to the sovereign degree in a soul, it takes the place of all the sciences, which men invented only to make up for the lack of this wisdom.

Therefore, Sirs, I regard this Great Monarch as a perfect and finished model, of which every aspect is admirable, and who is put among you so that you may make faithful images of him which shall never perish; so that the actions of this Prince, which are the present happiness of his people, shall be still useful to posterity, for the great examples they will give to Princes in the ages to come. That is the worthy object of your labors and of your sleepless nights. As for myself, Sirs, I will strive, with the help of your learned discussions, to follow along far behind you, and in time to deserve the place which it has pleased you to give me today in this Illustrious Company.

7. The personal reign of Louis XIV began with the death of Cardinal Mazarin in I66I.

8. In conflicts between 1661 and 1671 , Louis XIV defended the Holy Roman Empire against the Turks and engaged in the War of Devolution, acquiring a large area of Flanders from the Spanish and forming alliances with the Dutch, several German princes, and the English, from whom he purchased control of Dunkirk. The alliance with the Dutch would end, however, with Louis's invasion of Holland in June 1672 . 


\section{APPENDIX C \\ Charles Perrault: Preface to the Tales in Verse (collection published 1695); Dedication to the Tales in Prose (1697)}

[Note: Although Perrault's fairy tales, particularly the ones in prose, have become universally familiar in Western culture, the prefaces remind us that they were an artistic creation of late seventeenthcentury France, and of an author with a specific polemical intent. Perrault alludes to the Quarrel of the Ancients and Moderns and offers his tales as modern rivals to the classical fable, superior in their moral character and pertinent to the interests of an adult, sophisticated audience. The delicate conceit of deprecating the tales as amusements for children, and signing the dedication of the prose tales with the initials of his son, was a common practice for authors of works in a lighter vein and was disregarded by his contemporaries. $]^{\mathrm{r}}$

\section{PREFACE \\ (Griselidis, Donkey-skin, The Ridiculous Wishes)}

The manner in which the Public has received the Pieces in this Collection, as they have been given to it separately, is a kind of assurance that they will not displease in appearing all together. It is true that some persons who affect to appear very serious, and who have the intelligence to know that these are Tales written for pleasure, and that the subject is not very important, have regarded them with disdain; ${ }^{2}$ but one has had the satisfaction of seeing that persons of good taste have not judged them in the same way.

They have been pleased to notice that these bagatelles were not pure bagatelles, that they incorporated a useful moral, and that the light story in which they were enveloped was chosen only to make them enter more agreeably into the imagination, and in a manner which both instructs and entertains. This ought to be enough for me not to fear the reproach of having amused myself with frivolous things. But since I must deal with many people who pay no attention to reasons, and who can only be moved by the authority and the example of the Ancients, I will satisfy them on this point. The Milesian Fables ${ }^{3}$ which were so famous among the Greeks, and which were the delight of Athens and Rome, were no different from the Fables of this collection. The story of the Matron of Ephesus ${ }^{4}$ is of the same nature as that of

I. The authorship and origin of Perrault's fairy tales is more fully discussed in Jeanne Morgan, Perrault's Morals for Moderns (New York/Berne/Frankfurt am Main: Peter Lang, 1983).

2. Boileau is the obvious target of this criticism.

3. Miletus, an ancient Ionian city in Asia Minor, was associated with the sermo miletius, or milesian fable, a tale with imaginative, often fantastical elements blended with commentary on human mores.

4. "The Matron of Ephesus" was a tale appearing in Petronius's Satyricon (first century A.D.). In this story, a wife who is renowned for her virtue makes loud lament when her husband dies, and vows that she will shut herself in his tomb and die with him. A handsome soldier who has been hired to guard the body of another man hears her commotion, and goes to investigate; he eventually persuades her to live, and the virtuous matron has a tryst with the lowly guard. Meanwhile, the body which he had been hired to watch over is stolen, and the two decide to open her husband's tomb and use his body to replace the missing one. This tale was amusingly recounted by La Fontaine in his Poème du Quinquina (1682) 
Griselidis: they are both Nouvelles, that is, tales of things that might have happened, and which have nothing which absolutely wounds our sense of verisimilitude. The fable of Psyche written by Lucian and by Apuleiuss is a pure fiction, and an old woman's tale like that of Donkey-Skin. Therefore we see that Apuleius has it told by an old woman to a young woman whom thieves had abducted, just as Donkey-Skin is told every day to Children by their Governesses, and by their Grandmothers. The Fable of the Laborer who obtains from Jupiter the power to make it rain or shine as he wishes, and who made use of it in such a way that he harvested nothing but straw with no seeds, because he had never asked for wind, or cold, or snow, or any such weather; all this is necessary, however, for plants to bear fruit: this Fable, I say, is of the same type as the Tale of the Ridiculous Wishes, if not for the fact that one is serious and the other comic; but both of them mean that men do not know what they need, and are happier being led by Providence, than if everything happens to them according to their desires. I do not believe that with such fine examples before me, from the wisest and most learned Antiquity, that one has the right to make me any reproach. I even claim that my Fables deserve more to be told than most of the ancient Tales, and particularly those of the Matron of Ephesus and Psyche, if one looks at them from the perspective of Morality, a principal aspect of every kind of Fable, and for which they ought to have been created. The entire moral that one can get from the Matron of Ephesus is that often women who appear to be the most virtuous are in fact the least, and therefore there are scarcely any who truly are virtuous.

Who cannot see that this Moral is very bad, and that it serves only to corrupt women by bad example, and make them believe that in abandoning their duty, they are only taking the common route? It is not the same with the Moral of Griselidis, which leads women to tolerate their husbands, and to show that there is no husband so brutal or so capricious that the patience of an honest woman cannot bring him around. As far as the Moral of the Fable of Psyche is concerned, a Fable which in itself is very agreeable and very ingenious, I will compare it to that of Donkey-Skin when I know it, but until now I have not been able to guess what it is. I know very well that Psyche means Soul; but I do not understand what is meant by Love, who is in love with Psyche, that is, the Soul, and still less what is added, that Psyche was supposed to be happy as long as she did not know by whom she was loved, but that she became very unhappy from the moment that she recognized him: there, for me, is an impenetrable enigma. All that one can say is that this Fable, like most of the Fables remaining to us from the Ancients, was created only to please, without regard for good morals, which they greatly neglected.

It is not the same with the tales that our forefathers invented for their Children. They did not tell them with the same elegance and embellishment with which the Greeks and the Romans ornamented their fables; but they always took great care that their tales should incorporate a praiseworthy and instructive moral. Everywhere virtue is rewarded, and every-

and reprinted in the Fables (1694 edition). The appearance of this latter work, only one year before Perrault's collection of verse tales, undoubtedly served as a direct inspiration for the sentiments he expresses in this Preface. La Fontaine's choice of subject in this tale, as well as the success of his Fables, which were openly inspired by Greek and Roman models, made him Perrault's direct rival on the side of the Ancients.

S. Marcus Annaeus Lucanus (A.D. 39-65) was a Roman poet and the nephew of the philosopher Seneca. Lucius Apuleius (A.D. I25-C. I80) was a philosopher and poet whose most famous work was The Golden Ass. 
where vice is punished. They all lead us to see the advantages of being honest, patient, clever, industrious, and obedient, and the evil that befalls those who are not. Sometimes it is Fairies who give as a gift to a young girl who spoke to them courteously, that with every word she speaks, a diamond or a pearl will come out of her mouth; ${ }^{6}$ and to another girl who spoke to them rudely, that with every word a frog or a toad will issue forth. Sometimes it is children who, for having obeyed their father or mother, become great Lords; or others, who having been bad and disobedient, fall upon horrifying misfortunes. However frivolous and bizarre all these Fables may be in their adventures, it is certain that they arouse in Children the desire to resemble those whom they see become happy, and at the same time, the fear of the misfortunes into which the wicked have fallen, because of their wickedness. Is it not praiseworthy for Fathers and Mothers, when their Children are not yet capable of appreciating solid truths which are stripped of any ornamentation, to make the Children like them, and if one might say, to make them swallow them, by wrapping them in tales which are enjoyable and proportioned to the weakness of their young age? It is unbelievable with what greediness these innocent souls, of which nothing has yet corrupted the natural rectitude, receive these hidden instructions; one sees them sad and cast down, while the Hero or the Heroine of the Tale are unhappy, and shouting with joy when the moment of their happiness arrives; in the same way, after having impatiently tolerated the prosperity of the wicked man or woman, they are delighted to see them at last punished as they deserve. These are seeds that one sows, which at first produce only feelings of joy or sorrow, but which do not fail to bloom into good inclinations.

I might have made my Tales more agreeable by stirring into them certain liberties with which they are customarily enlivened; but the desire to please has never tempted me enough to violate a law which I imposed upon myself, never to write anything that could wound either modesty or seemliness. Here is a Madrigal that a young Lady7 of great wit has composed on this subject, and that she wrote below the Tale of Donkey-Skin which I had sent to her.

The Tale of Donkey-Skin is here told with such naïveté, 8 that it did not entertain me less than when, near the hearth, my Nurse or my Governess held my mind enchanted by telling it. One may see in places some indications of Satire, but which, without bitterness and without malice, give pleasure for everyone equally to read. What pleases me even more in its simple sweetness, is that it amuses and makes us laugh, without a Mother, Spouse, or Confessor finding anything to rephrase.

\section{TO MADEMOISELLE ${ }^{9}$}

(Histories or Tales of Past Times, with Morals, 1697)

MADEMOISELLE, one will not find it strange that a Child has taken pleasure in composing the Tales of this Collection, but one will be astonished that he should have the boldness to

6. This tale, The Fairies, would later appear in the 1697 collection of tales in prose. It is more commonly known in English as Diamonds and Toads.

7. Marie-Jeanne Lhéritier de Villandon (1664-1734), Perrault's niece. The original poem is in twelve lines of variable length and rhyme scheme.

8. Naïveté in the seventeenth century also meant naturalness, without artifice.

9. Élisabeth-Charlotte d'Orléans (1676-1744), the niece of Louis XIV, was nineteen years old in 1695, the date of the hand-lettered presentation manuscript of the tales. 
present them to you. However, MADEMOISELLE, whatever disproportion there may be between the simplicity of these stories, and the enlightenment of your mind, if one examines these Tales well, it will be seen that I am not as much to blame as I first appear. They all contain a very sensible Moral, which reveals itself to a greater or lesser extent, according to the degree of penetration of those who read them; moreover, as nothing reflects the vast breadth of a mind so much as its ability to raise itself up to the greatest things, and at the same time to lower itself to the smallest, it will not be surprising that the same Princess, to whom Nature and upbringing have made familiar what is most elevated, should not disdain to take pleasure in bagatelles such as these. It is true that these Tales give an image of what happens in the most humble Families, where the praiseworthy impatience to instruct their children makes them imagine Stories lacking in reason, to accommodate them to these same children who have none as yet; but for whom is it more fitting to know how these People live, than for those Persons whom Heaven has destined to lead them? The desire for this knowledge has urged Heroes, and even Heroes of your lineage, even into huts and cabins, to see at close hand and for themselves the most private things that took place there, this knowledge having seemed to them to be necessary for their complete instruction. Be that as it may, MADEMOISELLE,

Could I have made a better choice, to make what is incredible in the Fable seem realistic? And did any Fairy of former days ever give a young Creature more gifts, and exquisite gifts, than Nature has bestowed upon you? 10

I am, with very deep respect, MADEMOISELLE, of Your Royal Highness, the very humble and very obedient servant, P Darmancour. ${ }^{\text {II }}$

10. In the original text, this passage is a rhymed strophe of six lines.

II. Pierre Perrault (1678-1700), Charles's youngest son and the namesake of his uncle the Receiver General, was also known as Pierre Darmancour, perhaps in an effort to avoid the notoriety attached to his father. 


\section{APPENDIX D \\ Charles Perrault: "Some Superstitions and Popular Errors" and "Paradox: That it is not useful for every man to become learned"}

[Note: This manuscript in Perrault's own hand was bound together in the same volume as the manuscript of the Memoirs, Bibliothèque Nationale Fonds Français 2399I, pp. 85, 85-b, 86. It is dated is October 1702, approximately seven months before his death. Superstitions reflects the Perrault of the fairy tales, amused and fascinated by folk tradition. The Paradox, however, echoes the instructive and yet faintly disillusioned tone of the Memoirs, as Perrault sought to make sense of his own experience and to leave a meaningful personal legacy. In this document, as in the Christian Thoughts, Perrault found solace in philosophical reflection at the very end of his turbulent career.]

\section{SOME SUPERSTITIONS AND POPULAR ERRORS}

Whoever could gather them all would make the fattest book there ever was.

That it is a bad omen to be thirteen at table, and that someone among them will die during the year. If that were true, it would be even worse to be fourteen at table.

That to eat green walnuts before St. Laurent's Day [Io August] also gives the toothache to those who eat them.

That there is less marrow in the bones of animals when the moon is on the wane than when it [is] full, that there is more flesh on $[\ldots]^{\mathrm{r}}$ in a full moon than at other times, etc.

Talis tota qualis quarta nisi mutetur in sexta. ${ }^{2}$

When it rains on Saint Germain's Day [28 May], it rains for forty days afterwards.

There is no certainty in any type of prediction whatsoever, particularly with horoscopes. It is true that it happens sometimes that they [come out] well, but it would be better if they never fell true, because if they never fell true, one could know for a certainty whatever was the opposite of what they had predicted.

That there are lucky days and unlucky days.

That stones are stubborn. ${ }^{3}$

That to encounter a gelded animal in the morning upon leaving the house brings bad luck. That to spill salt on the table where one is eating brings bad luck.

That to give a gift of a knife or scissors breaks the bond of friendship and good terms.

That whoever laughs on Friday cries on Sunday.

That finding a weasel in one's path is a bad omen.

I. This word is illegible in Perrault's writing, and may be coquille, mollusk or shellfish.

2. A free Latin translation: "As for instance a fourth is similar to a whole, except when it is changed into a sixth"; this confusing riddle may refer to the moon, luna, because of the feminine forms of tota, quarta, and sexta.

3. In French, opiniâtre, which also means self-opinionated or unyielding. 
That the seventh son born without any daughter between two of them is able to cure a rash, and the seventh daughter born without any son between them is able to cure ringworm.

That there is always some moment on a Saturday when one can see the sun shine.

That a broken glass, porcelain dish, or mirror foreshadows some bad luck.

That to be in a certain place or near certain people brings bad luck in gambling.

That there are frosty saints in the month of April, that is that it frosts more often on those saints' days than on the day before or the day after.

If [sic] a one-eyed man, or a man with a limp, or a man with a hunchback is more crazy or is more clever than another.

That the song of an owl or of a osprey foreshadows the death of a sick man.

That to fast on Easter prevents one from having a fever during the whole year, and at least until the next Easter.

That an odd number is luckier than an even number.

That winter is always like St. Denis' Day [9 October], cold if it is then cold, rainy if it is then rainy, serene if it is then serene, etc.

That one should not have oneself purged or have a bath on canicular days. 4

\section{PARADOX: THAT IT IS NOT USEFUL FOR EVERY MAN TO BECOME LEARNED}

I have had occasion to tell my children something that no Father has perhaps ever said to his children. Take care, I tell them, not to throw yourself wholeheartedly into the study of science, unless you have truly examined whether your mind is strong enough to carry the weight and not be overcome by it; because it is with knowledge as it is with wine, that one should not take more of one or the other than as much as one can carry, and in such a way that the mind always remains the master. To know the good or ill effect of knowledge on the person who studies, one has only to see whether in conversation he cannot prevent himself from quoting passages from authors he has read, for that is a sign that he has not digested what he is reading, since he gives it back exactly as he took it. 5 He should therefore cut back upon his studies, or even abandon them, if he cannot refrain from the bad habit of quoting passages at every turn. It is evident in that case that his knowledge dominates and governs his mind, whereas his mind ought to govern his knowledge.

4. Canicula, "little dog" in Latin, was the name given to the star Sirius, and the "dog days" of July and August refer to the period when Sirius rises and sets with the sun, associated with days of exceptional heat.

s. This parallel between understanding and digestion was also made by the sixteenth-century philosopher Montaigne, in his essay On the Education of Children. 


\section{APPENDIX E \\ Paul Tallemant: "Funeral Eulogy of Charles Perrault"}

[Note: On 3I January 1704, over eight months after Perrault's death, his friend the Abbé Tallemant delivered a eulogy of him before the French Academy, scene of so many of Perrault's triumphs and conflicts. The speech was published in 1704 (Paris: Coignard), and was also reproduced by the Journal des Savants in the issue of ro March 1704. Tallemant's speech is a fitting epitaph for a remarkable man, and it is presented here with the prefatory remarks of the Journal's editor.]

[Journal:] One sees in the speech by Monsieur the Abbé Tallemant a friend who regrets the absence of his friend, who talks with us about the good qualities of the mind and heart of Monsieur Perrault, who asks that he be permitted to throw a few flowers upon the tomb of his brother writer, and who acquits himself of this duty in a manner equally worthy of a friend and an Orator. In its founding, the Academy had decreed as one of its first statutes that upon the death of the Academicians, their eulogy and epitaph would be composed in prose and in verse. This rule appears to have been officially observed only for the death of Monsieur Bardin, ${ }^{1}$ for whom Monsieur Godeau, the Bishop of Vence, ${ }^{2}$ wrote the Eulogy, Monsieur the Abbé de Cérisi ${ }^{3}$ the epitaph in prose, and Monsieur Chapelain the epitaph in verse. Monsieur the Abbé Tallemant asks here that he be permitted to renew this early rule on behalf of his famous colleague, and to comfort his sorrow, by giving the public a faithful account of his friend's virtue. We will report an abridgment of what Monsieur the Abbé Tallemant says on this subject, and we will report it with even greater pleasure for the fact that we will at the same time satisfy what established practice demands in a newspaper, where it is the custom to make mention of those who have recently died, after having had a distinguished career in literature.

[Tallemant:] The French Academy has seen some great persons die; but one will not fear being repudiated if one says that those who have distinguished themselves for the greater advantage of this Company, and for the progress of the fine arts, should be even dearer to it than the others. A Minister who is clever in all things, but especially in the art of knowing men, sees in Monsieur Perrault an essence of probity and justice which will draw forth his complete confidence. This faithful confidant thinks of nothing other than the examination in good faith of everything which could make the sciences and the arts flourish. He spends his nights in preparing his Memoirs, which quickly gave shape to a golden age for all famous men, ${ }^{4}$ in whatever science and in whatever art this may be. Fortune and virtue are reconciled, good things seek out those who, without secret plotting and without ambitious desires, devote

I. Pierre Bardin (1590-1637) was a founding member of the French Academy.

2. Antoine Godeau (1605-1672), Bishop of Grasse and Vence, was a founding member of the Academy who was known as an author in prose and verse.

3. See Part I, note 25.

4. The word Memoirs here may mean official memoranda, or may refer to Perrault's book Illustrious Men Who Have Lived During Our Century (1696-1700). It is unlikely that Tallemant was aware of the Memoirs, still in manuscript, which do little to flatter the famous men of Perrault's acquaintance. 
themselves only to earning these blessings. A great scene opens before the whole universe: painting and sculpture recapture their former and greatest honors. Astronomy, physics, and the most hidden sciences are cultivated with success. Eloquence and poetry shine in all quarters. Monsieur Perrault, without ostentation, without jealousy, and without seeking personal advantage, puts everything in motion: he produces and sets to work all those whose rare talents are known to him by reputation. His natural capacity in all kinds of arts, makes him easily take notice both of those who excel, and those who have that kind of genius which leads to perfection; his uprightness, full of love for truth, gives him zeal for their good fortune, without his ever being concerned for his own.

We know everything he did for the Academy, and with what ardor he pursued the details of his work at the Louvre. All favors came without difficulty, and almost always before being asked. What did he not do for well-known painters, famous sculptors, great architects, renowned astronomers, illustrious physicists? Monsieur Perrault always encouraged them, loved them, and protected them; he was always concerned with making their merits known, in praising their works and in soliciting on their behalf the rewards worthy of them and of the magnificence of the Prince whom they served. Amidst all this care for others, he did not think of himself, or of his illustrious brothers, or of his own family. All those who surrounded Monsieur Colbert took advantage of his favor, and made their own fortunes; Monsieur Perrault thought only of pleasing him, and furnishing him the means of advancing the progress of all the arts, in order to satisfy that Minister's extreme passion for the greatness of his Master, and for the glory of the Nation.

Death took too soon from France a Minister who was so useful to the State, and at the same time dragged down into a kind of disgrace, according to custom, those whom he had most loved. Monsieur Perrault was more sensitive to the loss of so great a personage than to his loss of the greater part of a rather small fortune, acquired by long work. His house becomes empty, he sees the ingratitude of several false friends; the grandeur of the post he had occupied occasions all kinds of difficulties for him: his virtue keeps him in safety, and his writing desk consoles him for everything. He finds once more near him the Muses, who had not yet abandoned him, and the ingenious Poem on Painting was the fruit of a few stolen moments devoted to occupations incompatible with Poetry. But from then on, his life was one long leisure, and the Academy has seen how he made use of it. It undoubtedly remembers the prodigious applause that the public gave to his Poem, in which he raised the era of his Prince above all the eras of antiquity. It was the source of a famous dispute, which was carried out with liveliness and eloquence on both sides, and which ended with a politeness worthy of the two illustrious Academicians who quarreled. In these kinds of disputes it is usual to push one's opinion a little beyond what is actually true. Perhaps Monsieur Perrault carried the love of his country too far; perhaps also his illustrious adversary did not have a high enough opinion of himself, and he was not as aware as he ought to have been, that by his own genius, he equaled and even surpassed those authors to whom he wished to defer all the beauty of his own works. Be that as it may, the quantity and diversity of Monsieur Perrault's poetry allow us to know the liveliness of his imagination, and the facility he had for composition. Nothing indicates this happy facility better than the Poem to Monsieur de la Quintinyes, a work worthy of being

5. "To Monsieur de la Quintinye, on His Book of Instructions for Fruit and Vegetable Gardens, an Idyll," was published in 1690 . This poem of eight printed pages in length was dedicated to the memory of La Quintinye, the King's gardener at Versailles, who had died on II November I688. 
associated with the Georgics of the prince of Latin poets. ${ }^{6}$

The beauty of his genius was yet what was most commendable in him: he was a man true in all things, admirably honest in his morals, and unshakably attached to religion and to all his duties, incapable of jealousy or hate, full of zeal and tenderness for his friends, selfless to the point of avoiding even the most innocent gain, always steady in temperament, always brilliant, always friendly in society. That was what kind of illustrious Academician we have lost in the person of Monsieur Perrault.

6. Georgica, a poem by Virgil in four books, depicted country life and agriculture. 


\section{CHRONOLOGY OF CHARLES PERRAULT'S LIFE AND PRINCIPAL WORKS}

I628 I2 January, birth of Charles Perrault in Paris, fifth surviving son of Pierre Perrault, a parliament lawyer, and Pâquette Leclerc. Charles and a twin brother, François, who died six months later, were baptized on I3 January at the Church of Saint-Étienne-du-Mont.

1636/1637 Began studies at the College of Beauvais, a private secondary school in the Rue Saint-Jean-de-Beauvais.

1643/1644 Perrault and a companion, Beaurain, left the College and pursued their studies independently for another three or four years. With the collaboration of older brothers Nicolas and Claude, composed a burlesque translation of the sixth book of Virgil's Aeneid.

I65I 27 July, was granted a degree in law from the University of Orléans.

I652 Death of his father Pierre.

I653 The Walls of Troy or The Origin of the Burlesque, book I, composed by Charles, Nicolas, Claude, and Beaurain. Book 2, composed solely by Claude, remained in manuscript until the twentieth century.

I654 Pierre Perrault, his eldest brother, purchased the post of Receiver General of Finances for the city of Paris, one of several tax collecting positions. Charles became his brother's part-time clerk and devoted himself to the composition of circumstantial poetry.

I657 Death of his mother; Pierre inherited her home at Viry, where a grotto designed by Charles won acclaim and brought him to the notice of Colbert.

I659 Portrait of Iris and Portrait of Iris' Voice. Authorship of the first of these poems was claimed by Philippe Quinault, who later apologized and became a colleague and supporter of Perrault.

I660 Ode on the King's Marriage and Ode on the Treaty of the Pyrenees, which brought him to the attention of Mazarin.

Dialogue between Love and Friendship.

I66I 9 March, death of Cardinal Mazarin.

April, The Mirror or the Metamorphosis of Oronte.

5 September, arrest of Fouquet and definitive rise to power of Colbert.

November, Ode to the King upon the Birth of Monseigneur the Dauphin.

I663 Discourse on the Acquisition of Dunkirk by the King.

February, appointed to serve as secretary of the Little Academy, the Academy of Inscriptions and Medals, which later became the Academy of Inscriptions and Letters. 
I664 I January, Colbert became Superintendent-Director General of Buildings, Arts, Tapestries, and Manufactories of France. Charles received first official "gratification" of $\mathrm{I}, 500$ livres "in consideration for his belles lettres"; also received I,500 livres for his work as a clerk of buildings. Pierre Perrault was accused of borrowing from public funds to pay his creditors and was forced to sell his post despite Charles's interventions on his behalf.

I665 Colbert became Controller General of Finances; Charles was named First Clerk of Buildings.

I668 Painting, a poem praising Charles Le Brun, and the satirical Parnassus Pushed to the Limit.

1670 Head and Ring Races run by the King and by the Princes and Nobles, commemorating the Carousel celebrations of 1662 , a work produced by the Little Academy for which Charles was chosen to be the author.

1671

23 November, elected to the French Academy.

I672 Named Controller General of Buildings, Gardens, Arts, and Manufactories of France, a title created for him by Colbert and which he was not required to purchase. Elected Chancellor of the French Academy, an administrative charge.

I May, married Marie Guichon, aged nineteen, who brought a dowry of 70,000 livres.

I673 Reelected Chancellor of the Academy.

2I August, Louis XIV donated 660 books to found an Academy Library, and Charles was named librarian.

I674 Critique of Opera, or Study of the Tragedy entitled Alceste, or the Triumph of Alcide, in which Perrault praised a work by Quinault and the musician Jean-Baptiste Lully over a similar play by Euripides.

167525 May, baptism of his first son, Charles-Samuel.

Collection of Diverse Works in Prose and in Verse.

I676 20 October, baptism of his second son, Charles.

I678 2I March, baptism of his third son, Pierre.

October, death of his wife, Marie Guichon.

1680/1682 Gradually relinquished duties as Controller General of Buildings to Colbert's son, the Marquis d'Ormoy. Annual pension for work in buildings no longer received.

1682 Banquet of the Gods for the Birth of Monseigneur the Duke of Bourgogne, the King's grandson.

I683 Is July, last memorandum recording his involvement with buildings.

6 September, death of Colbert, who was replaced by François Le Tellier, Marquis de Louvois. Exclusion from the Little Academy.

I685 I4 October, Louis XIV's revocation of the Edict of Nantes. Ode to New Converts.

I686 Saint Paulin, Bishop of Nôle, a long poem in the heroic style dedicated to Bossuet, which was to provoke much criticism among Academicians.

1687 27 January, at a session of the French Academy convened to celebrate the King's recovery from an operation, the poem The Age of Louis the Great was read aloud by the Abbé de Lavau. The ensuing debate over the superiority of ancient versus contemporary accomplishments escalated into the Quarrel of the Ancients and Moderns. 
I688 Parallel of the Ancients and Moderns, volume I, elaborating upon Charles's modernist position regarding the arts and sciences.

Genius, an epistle dedicated to Fontenelle.

October, Ode to Monseigneur the Dauphin on the Taking of Philisbourg.

1690 Parallel of the Ancients and Moderns, volume 2, regarding eloquence.

The Cabinet of the Fine Arts, a commentary upon a series of paintings executed by modern masters.

Idyll [dedicated] to Monsieur de la Quintinye, the King's gardener at Versailles who had died two years previously.

I69I 25 August, the Abbé de Lavau read another poem that would provoke controversy, The Marquise of Salusses or the Patience of Griselidis, inspired from a tale by Boccaccio.

1692 Parallel of the Ancients and Moderns, volume 3, regarding poetry.

La Chasse, a humorous poem.

1693 The Ridiculous Wishes, a verse tale published in the literary journal Le Mercure Galant (Gallant Mercury).

1694 Peau d'Âne (Donkey-Skin), the first verse tale not based upon a classical or known literary source, but upon what was considered folk tradition.

The Apology of Women, a defense of the female sex written in response to Boileau's Satire $X$ against women.

The Triumph of Saint Genevieve, Christian poem.

I695 Collection of Tales in Verse, containing the three previously published tales.

Earliest known manuscript of the Histories of Tales of Past Times, with Morals, dedicated to the King's niece, Elisabeth-Charlotte d'Orléans, and containing five new tales in prose.

I696 February, earliest publication of Sleeping Beauty in the Mercure Galant.

Illustrious Men who have Lived in Our Century, volume I, a polemical biography of seventeenth-century French writers, artists, scientists, statesmen, and theologians.

1697 January, publication of Histories or Tales of Past Times, with Morals, with the complete text of eight tales, and Parallel of the Ancients and Moderns, volume 4, regarding astronomy, geography, navigation, war, philosophy, music, and medicine.

6 April, his youngest son, Pierre, killed Guillaume Caulle in a duel; he was imprisoned but released shortly thereafter.

I699 Translation of Gabriele Faerno's Fables.

I700 March, death of Pierre Perrault, now a lieutenant in the Dauphin's regiment. Illustrious Men who have Lived in Our Century, volume 2.

I702 Ode to the King of Sweden.

I703 Is May, death of Charles Perrault in his home.

I7 May, interment in his parish church of Saint-Benoît, which was demolished in 1854 . 


\section{SELECTED BIBLIOGRAPHY}

\section{PRINCIPAL WORKS BY CHARLES PERRAULT}

L'Apologie des femmes. Paris: Veuve de Jean-Baptiste Coignard et Jean-Baptiste Coignard fils, 1694.

Griselidis, Nouvelle, avec le conte de Peau d'Ane et celui des Souhaits ridicules. Paris: Jean-Baptiste Coignard, I694.

Histoires ou Contes du temps passé, avec des moralitez. Paris: Claude Barbin, I697.

Les Hommes illustres qui ont paru en France pendant ce siècle, avec leurs portraits au naturel. 2 vols.

Paris: Antoine Dezallier, 1697 and 1700.

Mémoires de ma vie. Bibliothèque Nationale manuscript 2399I (fonds français).

Parallele des anciens et des modernes. 4 vols. Paris: Coignard, 1688, 1690, 1692, and 1697.

Recueil de divers ouvrages en prose et en vers. Paris: Coignard, 1675 .

Saint Paulin, évêque de Nôle, poème. Paris: Coignard, 1686.

Le Siècle de Louis le Grand, poème. Paris: Coignard, I687.

\section{CRITICAL EDITIONS OF PERRAULT'S WORKS}

Barchilon, Jacques, ed. Perrault's Tales of Mother Goose. New York: The Pierpont Morgan Library, 1956.

Barchilon, Jacques, and Catherine Velay-Vallantin, eds. Pensées chrétiennes de Charles Perrault. Tübingen: Biblio 17, no. 34, 1987.

Bonnefon, Paul, ed. Mémoires de ma vie. Paris: Librairie Renouard, I909.

Collinet, Jean-Pierre, ed. Contes. Saint-Amand: Gallimard, 1981.

Jauss, Hans Robert, and Max Imdahl, eds. Parallele des anciens et des modernes. München: Eidos Verlag, 1964.

Rouger, Gilbert, ed. Contes. Paris: Garnier, 1964.

Zuber, Roger, ed. Contes. Paris: Imprimerie Nationale, 1987.

\section{BIOGRAPHICAL CRITICISM}

Barchilon, Jacques, and Peter Flinders. Charles Perrault. Boston: Twayne, 198I.

Bonnefon, Paul. "Charles Perrault, commis de Colbert, et l'administration des arts sous Louis XIV." Gazette des Beaux-Arts (September 1908, II): 198-214; (October 1908, II): 340-52; (November 1908, I): 426-33.

" "Charles Perrault, Essai sur sa vie et ses ouvrages." Revue d'histoire littéraire de la France

II (1904): 365- 420; "Charles Perrault, Littérateur et Académicien: L'Opposition à Boileau." Revue d'histoire littéraire de la France I2 (1905): 549-610; "Les Dernières Années de Charles Perrault." Revue d'histoire littéraire de la France 13 (1906): 606-57. 
Ferrier-Caverivière, Nicole. "Les Mémoires de Charles Perrault et l'idée de raison d'état."

Cahiers de Littérature du XVIIe siècle, no. 9 (1987), 231-47.

Hallays, André. Les Perrault. Paris: Librairie Académique Perrin, 1926.

Morgan, Jeanne. Perrault's Morals for Moderns. New York/Berne/Frankfurt am Main: Peter Lang, I985.

—. "The Evidence for the Defense in Charles Perrault's Mémoires de ma vie." Papers on French Seventeenth Century Literature, vol. I3, no. 25 (1986), II3-24.

Soriano, Marc. Le Dossier Perrault. Paris: Hachette, 1972.

\section{DOCUMENTARY SOURCES}

Blondel, Jacques-François. Architecture française. 4 vols. (6 books). Paris: Charles-Antoine Jombert, 1752-I756. Rpt. Paris: Librairie Centrale des Beaux-Arts, 1904.

Boileau-Despréaux, Nicolas. Oeuvres. Ed. Georges Mongrédien. Bourges: Garnier, 196r.

Chantelou, sieur de [Paul Fréart]. Journal du voyage du Cavalier Bernin en France. Ed. Ludovic

Lalanne. Paris: Gazette des Beaux-Arts, I885. [Diary of the Cavaliere Bernini's Visit to France, translation by Margery Corbett, with an introduction by Anthony Blunt and annotation by George C. Bauer, published by Princeton University Press, 1985.]

Clément, Pierre, ed. Lettres, instructions et mémoires de Colbert. 5 vols. Paris: Imprimerie Impériale, I86I-I868.

Colbert 1619-1683, Exposition à l'Hôtel de la Monnaie, 4 octobre-30 novembre 1983. Alençon: Imprimerie Alençonnaise, 1983.

Depping, G. B., ed. Correspondance administrative sous le règne de Louis XIV. Vol. 4. Paris: Imprimerie Impériale, 1855 .

Documents du Minutier central concernant l'histoire littéraire (1650-1700). Paris: Presses Universitaires de France, 1960.

Furetière, Antoine. Dictionnaire universel. 3 vols. La Haye: Arnoud et Reiniers Leers, I690. Facsimile rpt., Genève: Slatkine Reprints, 1970.

Guiffrey, Jules. Comptes des Bâtiments du roi sous le règne de Louis XIV. Tome premier: Colbert. Paris: Imprimerie Nationale, I88I.

Histoire de l'Académie Royale des Inscriptions et Belles-Lettres. 3 vols. Amsterdam: n.p., I719. Rpt. Paris: Hippolyte-Louis Guerin, 1740.

La Médaille au temps de Louis XIV, exposition janvier-mars 1970. Paris: Hôtel de la Monnaie, 1970.

Le Journal des Sçavans pour l'année MDCCIV. Paris: Jean Cusson, 1704.

Le Mercure Galant. Paris: Barbin, 1672-1703.

Le Palais-Royal, catalogue de l'exposition au musée Carnavalet, 9 mai-4 septembre 1988. Paris: Edition Paris-Musées, 1988.

Maps of Paris: Gomboust (I652), Jean Boisseau (I654), Bullet/Blondel (1676), Turgot (1739). Bibliothèque Nationale Map Collection.

Piganiol de la Force, Jean-Aymar. Description historique de la ville de Paris et de ses environs. Nouvelle édition. Vol. 2. Paris: G. Desprez, i765.

Richelet, Pierre. Dictionnaire françoise. 2 vols. Genève: Jean Herman Widerhold, I680. Facsimile rpt., Genève: Slatkine Reprints, 1970. 
Sauval, Henri. Histoire et recherches des antiquités de la ville de Paris. 3 vols. Paris: Moette et Chardon, 1724. [written c. I655-1659]

\section{GENERAL WORKS}

Barbet, L.-A. Les Grandes eaux de Versailles, Installations mécaniques et étangs artificiels, description des fontaines et de leurs origines. Paris: Dunod et Pinat, 1907.

Berger, Robert W. "Charles Le Brun and the Louvre Colonnade." Art Bulletin 52 (December 1970): 394-403.

. Versailles, the Château of Louis XIV. University Park: Pennsylvania State University Press, 1985 .

Clément, Pierre. Histoire de Colbert et de son administration. 2 vols. $2 \mathrm{~d}$ ed. Paris: Didier, 1874.

Gould, Cecil. Bernini in France: An Episode in Seventeenth-Century History. Princeton: Princeton University Press, I982.

Hautecoeur, Louis. L'Académisme. Institut de France, publications diverses de l'année I956, no. 27. Paris: Firmin-Didot, 1956.

. Le Louvre et les Tuileries de Louis XIV. Paris and Brussels: G. Vanoest, 1927.

Jacquiot, Josèphe. Médailles et jetons de Louis XIV d'après le manuscrit de Londres. Paris: Imprimerie Nationale et Librairie Klincksieck, 1968.

Josephson, R. "Quelques dessins de Perrault pour le Louvre." Gazette des Beaux-Arts, 1927, 2.

Laprade, Albert, Nicole Bourdel, and J. Lafond. François d'Orbay, architecte de Louis XIV. Paris: Vincent, Fréal et Cie, 1960.

Marin, Louis. Le Portrait du Roi. Paris: Editions de Minuit, 1981. [The Portrait of the King, translated by Martha M. Houle, with foreword by Tom Conley. Minneapolis: University of Minnesota Press, 1988. Includes a translation of Peau d'Âne (Donkey-Skin) by Martha M. Houle.]

Meyer, Jean. Colbert. Paris: Hachette, 198I.

Mirot, Léon. "Le Bernin en France: Les Travaux du Louvre et les Statues de Louis XIV." Mémoires de la Société de l'Histoire de Paris et de l'Isle-de-France 3I (1904): 16I-288.

Mousnier, Roland. Les Institutions de la France sous la monarchie absolue, 1598-1798. 2 vols. Paris: Presses Universitaires de France, 1980.

Murat, Inès. Colbert. Paris: Fayard, 1980. [Translated by Robert Francis Cook and Jeannie Van Asselt. Charlottesville: University Press of Virginia, I984.]

Néraudau, Jean-Pierre. L'Olympe du roi-soleil, mythologie et idéologie royale au Grand Siècle. Paris: Sociètè d'Édition Les Belles Lettres, 1986.

Ranum, Orest. Paris in the Age of Absolutism: An Essay. New York: John Wiley \& Sons, 1968. Sauvel, Tony. "Les Auteurs de la Colonnade du Louvre." Bulletin monumental 122 (1964): 323-47.

Thuillier, Jacques. "Réflexions sur la politique artistique de Colbert." In Un Nouveau Colbert, pp. 275-86. Paris: C. D. U. et Sedes, 1985.

Whiteley, Mary, and Allan Braham. "Louis Le Vau's Projects for the Louvre and the Colonnade." Gazette des Beaux-Arts 64 [Part I of article in November 1964, 285-96; Part 2 of article in December 1964, 347-62 (as Braham and Whiteley)]. 


\section{INDEX}

Academy of Architecture, 4, II4, 118

Academy of Inscriptions and Medals, 3, 4, I2,

$$
\text { 22, 42-47, 5I, 85, } 113-14
$$

Academy of Music, 4, 108

Academy of Painting and Sculpture, 4, 8, 57,

$$
60,62,118
$$

Academy of Painting in Rome, 57

Academy of Sciences, 4, 47-51, 92, 95, 99, II8

Ancients and Moderns, Quarrel of, 13-18, 20, $23,30,47,81,114,120-22,127$

Anne of Austria, 30, 46, 108

Arch of Triumph of Porte Saint-Antoine, Io, SI, 89-90

Arnauld, Antoine, II, 17, 33-36

Augustine, Saint, 34

Auzout, Adrien, 48, 50

Barberini, Antonio, 58

Bardin, Pierre, 126

Beaurain, Monsieur, 30-32

Beauvais, College of, 29-30, II3

Bellefonds, Marquis de, 58

Benedetti, Elpidio, 58-59

Benserade, Isaac de, 16

Bergerac, Cyrano de, 32

Bernini, Gian Lorenzo, 8-9, $56,58-79,84$; bust of King, 6I-63, 70, 72; character of, 62, 65-66, 78; departure of, 75-76; design for Louvre, 58, 6i, 63, 64-68, 70-72, 77; equestrian statue of King, 62, 79; opinion of Colbert, 66; quarrel with Perrault, 70-71; sayings of, 72-75

Bernini, Paolo, 6o, 75

Blondel, François, 48-49

Blondel, Jacques-François, 65, 104

Boileau, Gilles, 83

Boileau, Nicolas, 13, I5-17, 19-23, 29, 47, $80-81,83,114-15,120,127$

Bonneau, Thomas, 102, 104

Bonnefon, Paul, 26, 31, 39, 66, 86, 108, II2

Borel, Pierre, so

Bourdelin, Claude, 48, so

Bourzéis, Amable de, 42-44, 46, 48, II3

Brinvilliers, Madame de, 37

Buot, Jacques, 48
Burlesque poetry, $3 \mathrm{I}$

Butti, Abbé, 62, 64, 74-75

Cambert, Robert, 108

Carcavi, Pierre de, 48-49, 53

Carmelites, Church of, 75

Carraccio, Annibal, 73

Cartari, Giulio, 75

Cassagnes, Jacques, 42-44, 46, II3

Cassini, Jean-Dominique (Gian Domenico), $49,52-53$

Cérisy, Abbé de, 38, 126

Chambray, Roland Fréart, Sieur de, 60, 67

Chantelou, Paul Fréart, Sieur de, 8, 60, 62, $64,66-67,69,71,72-74,76$

Chapelain, Jean, I3, 23, 42-43, 46, 84, I13, 126

Charpentier, François, 46-47, 113-14

Chigi, Flavio (Cardinal), 59

Colbert, Jean-Baptiste, I, 3, 4, 6, 8-12, 22-24, $37,40-48,50-55,57-61,64-71,76-83$, 85-87, 89-90, 92-95, 97-113, I26-27; approval of Perrault's marriage, 106-7; character of, 65 ; creation of Academy of Sciences, 47-48, 5I-52; creation of Little Academy, 41-47; death of, 106, II2-I3; dismissal of Perrault, III-I2; injustice to Pierre Perrault, 102-6; opinion of Bernini, 66-68; opinion of Lully, 108-9; plan for Louvre, 54-6I, 64-71, 77-82; plan for Versailles, 92-94, 97-99; plan to mine metals, 94-95; resolution to close Tuileries Garden, 107-8; trouble with War Fund, 100-IoI

Colbert de Croissy, Charles, 50

Coquille, Claude, 104

Corneille, Pierre, I6

Cornelius, 30

Cortona, Pietro da, 56

Couplet, Claude-Antoine, 49

Créqui, Duke de, 58,60

Cureau de la Chambre, François, 84

Cureau de la Chambre, Marin, 48, 50, 83

Cureau de la Chambre, Pierre, 84

Dacier, Anne, 21 
Darmancour. See Perrault, Pierre (son)

Dauphin (King's son), 16, 44, 48

Davila, Enrico, 30

De la Hire, Philippe, 49-50

Despréaux. See Boileau, Nicolas

Dodart, Denis, 49-50

D'Orbay, François, 9-II, 8I

D'Orléans, Élisabeth-Charlotte

("Mademoiselle"), 18, 122-23

D'Orléans, Gaston, 108

D'Orléans, Philippe (“Monsieur"), 60, 76, 89

D'Ormoy, Marquis (Colbert's son), I2, II2

Douvrier, Louis, 95

Duclos, Samuel, 48, 50-5I

Du Metz, Sieur, 6o, 85, 106

Du Verney, G.-J.-P., 49-50

Étampes River, plan to divert to Paris, 90-91

Fairy tales, I, 18-20, 23-24, 120-23

Félibien, André, II 4

Fléchier, Esprit, 85

Fontainebleau Palace, II3

Fossier, Daniel, 6I

Fouquet, Nicolas, 3, 39, 45, 48, I03

Four Elements, tapestries of, 44-45

Four Seasons, tapestries of, 45

French Academy, 3, 1I-12, 19, 21-24, 38, 52, 83-89, I14-I5, II7-I9; activities of, 84-88; admission of Perrault, 83-84; Age of Louis the Great, reception of, II4-I5; consent given to address the King, 88-89; library, founding of, 85-86; Perrault's speech of thanks to, $117-19$; Tallemant's eulogy delivered to, 126-28

Frénicle de Bessy, Bernard, 48-49

Furetière, Antoine, 22

Galloys, Jean, 48

Gayant, Louis, 48-50

Girardon, François, 62, 74, 79, 97-98

Gittart, Daniel, 89

Gobelins River, plan to divert to Versailles, 94

Gobelins tapestries, devices for, 44-45

Godeau, Antoine, 126

Grace, doctrine of immediate vs. remote, $35-36$

Grammont, Duke de, 45, 76

Gratifications to Academies, 43, 50-5I

Guérin, Gilles, 97

Guiche, Marquise de, 83

Hardouin-Mansart, Jules, 10, 99
Horace, 30

Houdin, Antoine-Léonor, 7

Huet, Pierre-Daniel, IIs

Huygens, Christian, 48-49, 98

Jabach, Everard, 75

Jansenists, II, 33-36

Jolly, Denis, 99

Journal des Savants, 126

La Fontaine, Jean de, 17

La Quintinye, Monsieur de, 127

La Serre, Jean de, 30

Lavau, Abbé de, I3, I7, IIs

Le Brun, Charles, 6, 9, 57, 73-75, 80-8I, 89, 96, II2

Le Nôtre, André, 93, 107, I12-13

Le Tellier, François. See Louvois

Le Tellier, Michel, I2, 45, II3

Le Vau, François, 7

Le Vau, Louis, 6, 8-10, 52-54, 61, 79-82, 89

Lhéritier, Marie-Jeanne, 122

Lionne, Hugues de, 45, 58, 76

Little Academy. See Academy of Inscriptions and Medals

Loire River, plan to divert to Versailles, $9 \mathrm{I}$

Louis XIV, I, 3-4, 8-10, 12-13, 16, 20, 41-47, $58-63,66,68-71,73,76-8 \mathrm{I}, 85-86$, 88-90, 93-98, 100, 102-6, 108-II, II4-I5, II9; bust of, 6I-63; device of, 95; equestrian statue of, 62, 79; favors to Lully, 108-9; funds owed to Receiver Generals, I02-6; lays foundation stone of Bernini's plan, 69-70; letters of, 58-59; official history of, 45-47; Perrault's praise of, II9; praise of Louvois, IIO-II; protector of French Academy, 85-86; recovery from operation, II4-I5; reproach to Colbert, III; selection of Louvre design, 77-80; words of, $45-46$, $62,76,88,90,98$

Louvois, François Le Tellier, Marquis de, 12, 45, IIO, II3-I4

Louvre, 6-II, 4I, 5I, 53-83, 85, II2; acceptance of Perrault's plan, 79; attribution of design, 8-IO; colonnade, 8-9, II, 55; competition for design, 54-55; establishment of council on buildings, $80-82$; foundation laid, 68-70, 72; Italian vs. French construction, 63-64; plan to expand, 6-9, 4I, 5I, 53, 54; rejection of Bernini's plan, 77-79; scale model of, 82 Lully, Jean-Baptiste, 108-9 
Luxembourg Gardens, 30, 107

Malherbe, François de, I6

Mansart, François, 7, 9-10, 8I

Marchant, Nicolas, 48, 50

Marin, Denis, 104

Mariotte, Edme, 48

Marsy, Balthazard, 95

Marsy, Gaspard, 95, 97

Mazarin, Cardinal, I, 3-4, 6, 42, 46, 58, 88, II9

Mazarin Palace, 63

Medici, Catherine de, 76

Mercure Galant, II, 17-19, 2I

Michelangelo, 62, 73-74

Mining of metals, proposal for, 94-95

Molière, 109

Monmor, H.-L. Habert, Seigneur de, 47

Monsieur (Philippe, Duke d'Orléans), 60, 76, 89

Montagu, Abbé de, 76

Montespan, Madame de, 47, 97

Montigny, Abbé Jean de, 83

Niquet, Antoine, 49

Observatory of Paris, 10, 49, 5I-53

Ogier, Charles, so

Ogier, François, so

Opera, 108-9

Palais-Royal, 109-10

Papal nuncio (Monsignor Roberti), 6I, 7I, 73, 74

Pascal, Blaise, 36

Pastoral poetry, 3I

Pecquet, Jean, 48

Pelisson, Paul, 47

Perrault, Charles: Age of Louis the Great, I3, II4-I5, 127; A pology of Women, 20, 23; appointment as Controller General, 12; appointment to Little Academy, 43; birth, 29; burlesque translation of Aenead, 3I; character of, 22-24; childhood education, 29-30; Christian poems, I3, 23; Christian Thoughts, 21, 23; conversations with Colbert, 6I, 64-65, 68, 78, r04-9; defense of Palais-Royal garden, IIO; defense of Tuileries as public garden, 107-8; design for grotto of Versailles, 95-97; design for royal house, 9I; design for Arch of Triumph, 89; Dialogue between Love and Friendship, 39; exclusion from Little Academy, II3-I4; eulogy of, I26-28; fables, I6, 20; favorable reception of works I, II, I7-I8, 23, 84;

Griselidis, 17, 120-21; hostile reception of works, 13, 15, 18, 22-23; Illustrious Men Who Have Lived in Our Century, 15-16, 20, 23, 62, 126; involvement in Quarrel of Ancients and Moderns, IIs; law career, 36-37; marriage, 106-7; Memoirs, contribution of, 23-25; Memoirs, inspiration of, 2I; Memoirs, manuscript of, 26-27, II2; Memoirs, publication of, 26; odes, I, 6, 13, 16, 20, 42; Parallel of the Ancients and the Moderns, I5, 18, 20, 23, 115; pension received from King, 43; Portrait of Iris, 39, II6; Portrait of Iris' Voice, II6; quarrel with Bernini, 70-7I; rupture with Colbert, III-12; Saint-Paulin, 13, II4; speech to the Academy, II7-19; tales in prose, $1,18-20,23-24,122-23$; tales in verse, 17-18, 120, 122; The Walls of Troy, 3I-32

Perrault, Charles (son), 2I, 106

Perrault, Charles-Samuel (son), I06

Perrault, Claude (brother), 7, 9, I0, II, I3, I6, $21-23,26,31,48-52,54-55,79-82,89$, 96-99, II8; burlesque writings, 31; design of Louvre, 54-55, 79-82; design of Observatory, $\mathbf{5 2}$; designs for Versailles, 96-99; named to Academy of Sciences, 48; translation of Vitruvius, 118

Perrault, François (brother), 29

Perrault, Jean (brother), 6, 20, 31, 37

Perrault, Marie (sister), 3I

Perrault, Marie Guichon (wife), 20, 106

Perrault, Nicolas (brother), 20, 3I-35; defense of Arnauld, 33-35; inspires Provincial Letters, 36

Perrault, Pâquette Leclerc (mother), 29-30, 39

Perrault, Pierre (brother), 4, 6, 29, 3I-33, $35-36,37,39,42,102-6,123$; disgrace of, 102-6

Perrault, Pierre (father), 6, 29-30

Perrault, Pierre [Darmancour] (son), 18, 20, I06, 123

Perrin, Pierre, 108

Picard, Jean, 48, 92-94

Pinchesne, 40

Plessis, Marshal du, 74

Pope Alexander VII, 58-60, 7I

Pope Leo X, 73

Pope Paul III, 73

Pope Urban VIII, 58, 72 
Portraits, 39, 116

Port-Royal, 33-35

Poussin, Nicolas, 55, 60; Colbert's letter to Poussin, 55-57

Provincial Letters, origin of, 36

Quinault, Philippe, 16, I8, 23, 39, 84, $113-14$

Racan, 84

Racine, Jean, I6, 22, 47, 85, I15

Rainaldi, Domenico, 56

Raphael, 73-74

Ratabon, Antoine de, 6, 4I, 54

Receiver General of Finance, post of, 4-5, 37, 102-6

Regnaudin, Thomas, 97

Régnier Desmarais, François, 84

Rembrandt, 73

Richelieu, Cardinal, 3, 58, 83, 88, 109, 117-18

Richer, Jean, 49

Riquet, Pierre-Paul, 9I-94

Roberval, Gilles de, 48-49, 53

Romano, Giulio, 74

Rose, Toussaint, 88

Rossi, Matthia di, 64, 71, 75-76, 78

Sabbathier, François, I02

Saint-Germain Palace, 3, 64, 77, 80, 83, 89, 93

Saint-Lambert, Abbé de, 48

Séguier, Pierre, 83,85 , 118
Sonning, Jean-Baptiste de, I04

Sorbonne, 3I-35, 50, II 3

Tacitus, 30

Tallemant, Paul, 2I, 85, II3-I4, I26-28

Tedesco, Il, 73

Tertullian, 30

Titian, 73

Trajan Column, 74

Trianon Palace, 99

Tuileries Garden, proposal to close, 107-8

Tuileries Palace, 3, 6, 77

Vallière, Louise de la, 75, nio

Varet, Alexandre-Louis, 33-34, 36

Vaux-le-Vicomte, 3, 45, 93

Versailles, 3, 8, 16, 19, 24, 51, 63, 79, 83, 88, 9I-III, I27; Clagny pool, 98; construction costs of, III; grotto, 95-97; Latona fountain, 95; marble and bronze vases, 97; Trianon, 99; water pathway, 97

Vigarani, Carlo, 75, 109

Vigarani, Gaspare, 75

Villedo, Michel, 69

Villeroi, Duke de, 45

Virgil, 30-3I, 128

Viry, Perrault house and grotto, 39-40, 91

Voiture, Vincent, 40

Warin, Jean, 63, 69 









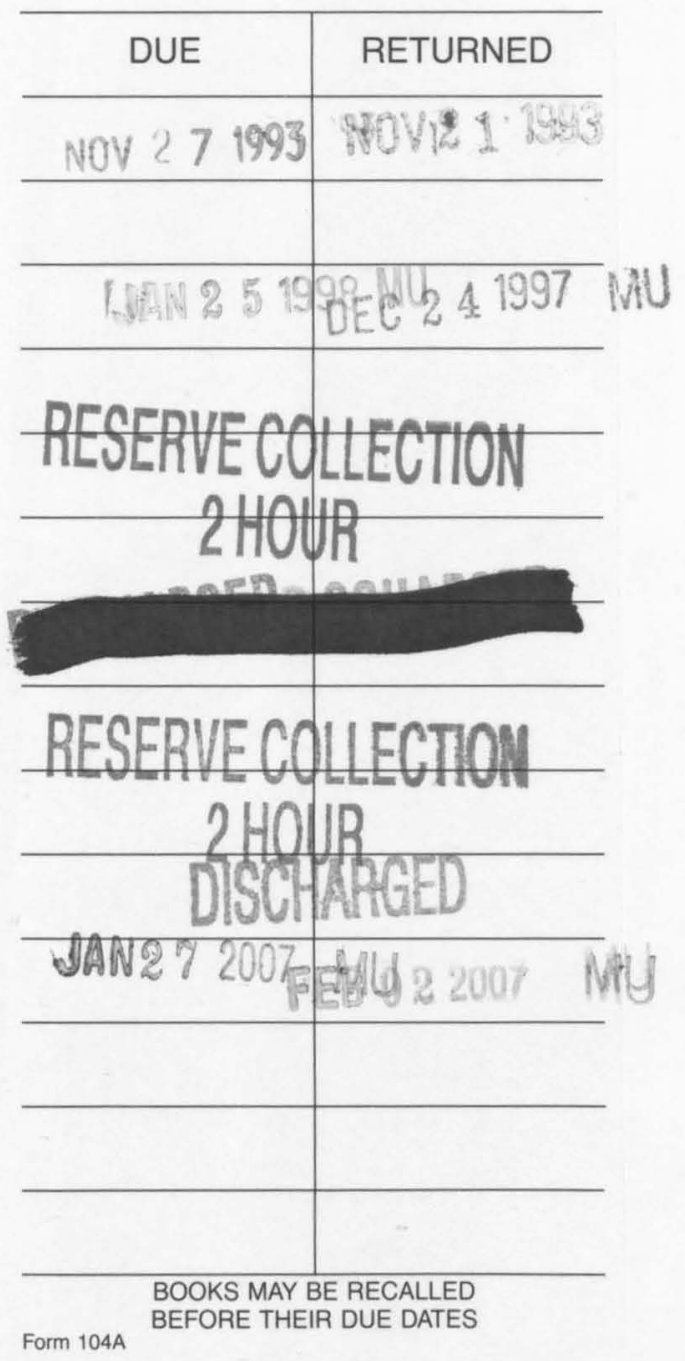




\section{0-500728821}

